NBER WORKING PAPER SERIES

\title{
PARENTAL RESPONSES TO CHILD SUPPORT OBLIGATIONS: EVIDENCE FROM ADMINISTRATIVE DATA
}

\author{
Maya Rossin-Slater \\ Miriam Wüst \\ Working Paper 22227 \\ http://www.nber.org/papers/w22227 \\ NATIONAL BUREAU OF ECONOMIC RESEARCH \\ 1050 Massachusetts Avenue \\ Cambridge, MA 02138 \\ May 2016
}

We thank Paul Bingley, Marianne Bitler, Janet Currie, Olivier Deschenes, Mette Gortz, Nabanita Datta Gupta, Hilary Hoynes, Peter Kuhn, Ilyana Kuziemko, Shelly Lundberg, Mai Heide Ottosen, Petra Persson, and Heather Royer, as well as seminar participants at UC Santa Barbara, the University of Copenhagen, Stanford University, UC Riverside, the Norwegian School of Economics (NHH), Boston University, University of Chicago-Harris School, RAND, the Public Policy Institute of California, the SFI annual conference, the ESPE annual conference, the University of Wisconsin IRP Summer Research Workshop, the NBER Summer Institute Children's Meeting, the EALE conference, the All-California Labor Economics Conference, and the AEA meetings for their helpful comments. Rossin-Slater thanks the Danish National Centre for Social Research (SFI) for a research fellow appointment that allows access to the data, and gratefully acknowledges funding from the Regents Junior Faculty Fellowship at UC Santa Barbara. Wust gratefully acknowledges financial support for the research of this paper from the Danish Council for Independent Research (grant 11-116669). All errors are our own. The views expressed herein are those of the authors and do not necessarily reflect the views of the National Bureau of Economic Research.

NBER working papers are circulated for discussion and comment purposes. They have not been peer-reviewed or been subject to the review by the NBER Board of Directors that accompanies official NBER publications.

(C) 2016 by Maya Rossin-Slater and Miriam Wüst. All rights reserved. Short sections of text, not to exceed two paragraphs, may be quoted without explicit permission provided that full credit, including $\odot$ notice, is given to the source. 
Parental Responses to Child Support Obligations: Evidence from Administrative Data Maya Rossin-Slater and Miriam Wüst

NBER Working Paper No. 22227

May 2016

JEL No. H40,I30,J12,J13,J16

\begin{abstract}
$\underline{\text { ABSTRACT }}$
We leverage non-linearities in Danish child support guidelines and rich administrative data to provide causal estimates of parental behavioral responses to child support obligations. We estimate that a $1,000 \mathrm{DKK}(\$ 149)$ increase in a father's obligation is associated with a $506 \mathrm{DKK}$ (\$75) increase in his payment. A higher obligation also reduces father-child co-residence, pointing to substitution between financial and non-pecuniary investments. Further, obligations increase parental post-separation fertility, and reduce labor supply among high-income fathers. Our findings suggest that government efforts to increase child investments through mandates on parents can be complicated by their behavioral responses to them.
\end{abstract}

Maya Rossin-Slater

Department of Economics

University of California, Santa Barbara

2127 North Hall

Santa Barbara, CA 93106

and NBER

maya.rossin-slater@ucsb.edu

Miriam Wüst

The Danish National Center for Social Research

Herluf Trolles Gade 11

1052 Copenhagen

miw@sfi.dk 


\section{Introduction}

Most modern governments engage in redistributive policies, whereby income is transferred from individuals who are taxed to individuals who receive benefits. The implicit "donors" and "recipients" under these policies usually do not have any direct connection, and a large body of research has examined the behavioral responses of these two groups separately. For instance, the literature on the elasticity of taxable income examines the behavior of donors, while studies on fertility and labor supply effects of welfare programs focus on the actions of the recipients. ${ }^{1}$

As a result of the sharp increase in the proportion of children growing up in single-parent households, a different type of redistributive policy has evolved in the last several decades. In the hopes of improving these children's financial circumstances and shifting the burden of their support away from traditional welfare programs, governments mandate child support payments from non-custodial parents to the custodial parents and their children. ${ }^{2}$ Under this redistributive policy, the donors (typically, fathers) have a clear connection to the recipients (typically, mothers and children). Thus, its impacts depend on both the recipients' and the donors' preferences and constraints, as well as their interactions with one another.

In this paper, we apply a novel identification strategy to rich administrative data from Denmark to estimate the causal effects of child support obligations on a wide range of parental behaviors, thus studying responses among both donors and recipients. Our empirical analysis is motivated by existing theoretical models that highlight the intertwined nature of parental incentives and the complexity of their potential responses to child support obligations (see, e.g.: Weiss and Willis, 1985; Willis, 1999; Flinn, 2000). These models demonstrate that child support obligations do not resolve the underlying collective-goods problem among separated parents, as custodial parents have full allocative power over how to spend the non-custodial parents' payments. As a consequence, non-custodial parents may view their obligations as taxes, which may not always benefit their children. Moreover, when the child support obligation is linked to the custody arrangement (e.g., if

\footnotetext{
${ }^{1}$ For surveys of research on the elasticity of taxable income, see Gruber and Saez, 2002; Saez et al., 2012; Piketty and Saez, 2013. For surveys of research on behavioral responses to welfare programs see Hoynes, 1997; Moffitt, 1998; Schoeni and Blank, 2000; Moffitt, 2002.

${ }^{2}$ In the U.S., 9 percent of children under age 18 lived with only one biological parent in the household in 1960, while over 26 percent do today. Many Western European countries have similar rates - for example, about 22 percent of British children, 18 percent of Danish children, and 15 percent of German children live with only one parent. Children in single-mother households are disproportionately low-income. In the U.S., children in single-mother households are twice as likely to live in poverty relative to the average child. In Denmark (the setting for this paper), children in single-mother households are three times more likely to live in poverty relative to the average child. Data for U.S. are from the 1960 Decennial Census and the 2013 Current Population Survey. Data for the European countries are from EU Community Statistics on Income and Living Conditions, 2007. For more information on child poverty rates in Europe, see: http://www.unicef-irc.org/publications/pdf/rc10_eng.pdf.
} 
the obligation is different depending on whether the parents share custody), it may affect parental decisions about child custody, as well as other voluntary and non-pecuniary investments and contact with children. These decisions may in turn have downstream effects on other parental behaviors, including family formation with new partners and labor market activities.

The existing evidence on the causal effects of child support obligations is limited. Researchers are faced with two main challenges. First, child support obligations are not randomly assigned, making it difficult to disentangle their causal effects from the possible influences of other (unobservable) differences between families. Second, researchers face a substantial data constraint, especially in the United States, where most of the existing work has been set (see Garfinkel et al., 1998; Del Boca, 2003; Lerman and Sorenson, 2003; Pirog and Ziol-Guest, 2006; Cancian et al., 2011; Huang and Han, 2012 for some surveys). Most U.S. data sets contain information on individuals in a given household, making it impossible to link children to their non-custodial parents. Additionally, much of the existing literature uses survey data with self-reported income measures, which may be missing or inaccurate for a significant fraction of respondents (Weinberg, 2006). Since child support obligations are largely determined by parental income, it is difficult to match non-custodial parents to their obligations. To our knowledge, no existing studies have exploited variation in child support obligations across individuals with different incomes.

This paper addresses the first challenge by using quasi-exogenous variation stemming from nonlinearities in and yearly changes to the child support formula in Denmark, where obligations are set according to an annually updated step function of the non-custodial parent's income.

We address the second challenge by taking advantage of administrative data on the universe of Danish children linked to their parents regardless of their residence status and with precise information on parental income. We are thus able to comprehensively analyze the effects of child support obligations on fathers' payments to children, fathers' likelihood of co-residence with their children, as well as both parents' post-separation family formation and labor market behavior. ${ }^{3}$

Our estimation strategy is analogous to the simulated instrumental variables (IV) approach in Dahl and Lochner (2012) and Chetty et al. (2011), who use expansions in the U.S. Earned Income Tax Credit (EITC) benefits - which have differentially impacted families with different incomes and numbers of children - to identify the causal effects of family income on child outcomes. ${ }^{4}$ In our

\footnotetext{
${ }^{3}$ Our analysis focuses on studying the effects of fathers' child support obligations because they are much more likely than mothers to become the non-custodial parents in case of separation. According to Statistics Denmark, in 2010, about 26 percent of children lived with only one biological parent (and potentially their new partners). Out of them, 23 percent lived with only their mothers, while 3 percent lived with only their fathers. While we observe information on whether the father lives with his child post-separation, we purposely do not drop these fathers since we show that residence with the child is an outcome that can be affected by the child support obligation.

${ }^{4}$ For two other recent examples of the simulated IV approach, see: (i) Milligan and Stabile (2011), who analyze
} 
setting, we exploit the structure of the Danish child support formula — which differentially impacts the obligations of fathers with different incomes, numbers of children, and years of separation-to analyze the effects of child support obligations.

Specifically, we use a father's predicted average child support obligation to instrument for his actual obligation over all post-separation years. This predicted obligation is calculated using solely the father's income and number of children measured in the year of separation; it does not take into account any changes to the father's income or number of children after separation, which may reflect endogenous responses.

Since the predicted average obligation is a direct function of each father's separation year, income in that year, and his number of children in that year, all of our specifications include flexible control functions with the main effects and double interactions of these three variables (following similar models in Dahl and Lochner, 2012; Chetty et al., 2011; Gruber and Saez, 2002, among others). Causal identification therefore relies on an assumption that - conditional on the father's separation year, income, and number of children in that year-the remaining (formula-driven) variation in predicted child support obligations is orthogonal to other determinants of parental behaviors. In support of this assumption, we: (i) provide evidence that the variation in predicted obligations is uncorrelated with numerous parental characteristics that are not used in setting them (such as each parent's education, each parent's age, and maternal income), (ii) show that the predicted obligations do not impact selection into divorce, separation, or out-of-wedlock/cohabitation childbearing in the first place, (iii) show that our results are robust to different ways of predicting average obligations, including using the father's income in the year before separation, and (iv) demonstrate that predicted obligations are uncorrelated with fathers' pre-separation labor supply behavior.

Our empirical results point to important parental behavioral responses to child support obligations. First, we show that child support obligations are moderately effective at increasing financial transfers from non-custodial fathers to children. Among the divorced and separated parents in our sample, a 1,000DKK (\$149) increase in a father's average annual child support obligation is associated with a 506DKK (\$75) increase in his average annual payment.

Next, we examine how the child support obligation affects the likelihood that a father ever resides with his child post-separation. In Denmark, parents who share equally in physical custody

the effects of Canadian tax benefits on child outcomes, and (ii) Brown et al. (2014), who study the long-term effects of Medicaid coverage on adult outcomes. This method is also motivated by the earlier work of Currie and Gruber (1996), who analyze the effects of Medicaid on infant health. Finally, the idea of using non-linearities in benefit or tax schedules to separately identify them from effects of income goes back to an older literature on tax evasion and tax prices (Slemrod, 1985; Feenberg, 1987). 
are not mandated to make child support payments; hence, a higher obligation may increase the incentive for the father to live with his child at least part of the time so to avoid making a larger payment. However, mothers, who have substantial say in custody decisions, have the opposite incentive to refuse to share custody and instead receive the higher payment. Moreover, fathers may treat financial transfers as substitutes for other forms of non-pecuniary investments and contact with children, which would also lead to a negative relationship between child support obligations and father-child co-residence. We find that these latter forces dominate in our data-an additional $1,000 \mathrm{DKK}$ in a father's average annual obligation leads to a 2 percent reduction in the likelihood that he resides with his child in at least one year post-separation.

We also analyze parental fertility responses. We find that a 1,000DKK increase in the father's average annual child support obligation leads to a 3.3 percent increase in the likelihood that the mother has an additional child post-separation, consistent with similar evidence on child support and fertility from the U.S. (Kim et al., 2015), and with a positive income-fertility relationship in other studies analyzing child tax and welfare benefits in Western Europe and Canada (Laroque and Salanié, 2008; Brewer et al., 2012; Milligan, 2005).

Fathers face unique fertility incentives in our context. First, our result on father-child coresidence suggests that an increase in the father's obligation may lead to less attachment to his existing children and more time available to invest in new offspring. Second, due to non-linearities in the child support guidelines and the fact that the per-child obligation is set according to the father's total number of children (including those born within subsequent unions) but only applies to his non-custodial children, some fathers can reduce their obligations by having more children within unions with new partners. We find evidence consistent with these positive fertility incentives: a 1,000DKK increase in a father's average annual obligation increases his likelihood of having a subsequent child by 3.7 percent. This effect is driven by fathers having children while married to or cohabiting with new partners, and by fathers who do not reside with their older children.

Finally, we find that fathers change their labor market behavior in response to child support obligations, while mothers do not. Overall, a 1,000DKK increase in a father's average annual child support obligation reduces his labor force participation by 0.2 percent. This average treatment effect masks important heterogeneity, however. Fathers with separation year incomes in the lowest income range, who must all pay the same lump-sum base amount, actually increase their labor supply. In contrast, fathers with separation year incomes in higher ranges - who must make supplemental payments and thus face a competing incentive to reduce their earnings - are the ones driving the decline in labor force participation. This labor supply decline reflects transitions into disability 
insurance and discretionary early retirement programs. As such, we provide additional support for the relationship between the relative value of labor market participation and the take-up of these programs, which has been previously documented both in Scandinavia (Bratsberg et al., 2010; Bingley et al., 2011) and in the U.S. (Black et al., 2002; Autor and Duggan, 2003).

Our findings suggest that government interventions into families with divorced and unmarried parents result in important parental behavioral changes that can distort their intended impacts on child investment levels, public spending, and overall child well-being. While fathers respond to child support obligations with increased financial transfers to their children, they also reduce their contact with them. Moreover, the increases in both parents' subsequent fertility rates point to possible reductions in the allocation of resources toward the existing children whom child support guidelines are meant to help. Finally, the decreases in paternal labor supply among higher-income fathers demonstrate the market distortions generated by the "tax-like" nature of child support mandates. Our results suggest that although child support mandates may shift some of the cost of single-mother household support from welfare programs to the non-custodial fathers, they also pass part of this cost on to other government programs such as disability insurance and early retirement. In sum, our results highlight the role of parental agency in family resource allocation, and suggest that government efforts to increase child investment levels through mandates on parents can be complicated by their behavioral responses to them.

The rest of the paper unfolds as follows. In Section 2, we describe the Danish child support system, which is crucial for understanding our identification strategy. Section 3 outlines a set of hypotheses (with a more formal model presented in Appendix B) to highlight the channels through which fathers' child support obligations could affect parental behaviors, and summarizes the existing evidence on child support. Section 4 describes our data, while Section 5 presents our empirical strategy. Section 6 presents our results and a variety of robustness tests, and Section 7 concludes.

\section{The Danish Child Support System}

In Denmark, a central government body called the State Administration (Statsforvaltningen) handles all issues related to divorce, separation, and child support. Parents who have sole physical custody of their children can request a formal child support agreement from this agency, which then assigns child support obligations to the non-custodial parents. As noted above, throughout this paper, we focus on the effects of non-custodial fathers' child support obligations; thus, from here on, we refer to the father as the default non-custodial parent. 
Child support obligations are determined according to a formula that is a step function of the father's current gross income; this step function changes every year and varies with the father's number of biological children under age 18, including any new children from subsequent unions. For example, a father with one non-custodial child and one child from a new union is treated as a two-child parent (although he only has to make payments for the non-custodial child).

The per-child obligation consists of a "normal amount" and an "extra amount," the sum of which all non-custodial fathers must pay. Non-custodial fathers with incomes above certain thresholds must also pay an additional percentage of the normal amount that ranges between 25 and 300 percent. The locations of the thresholds are increasing with the number of children. Moreover, in every year, the State Administration has increased both the normal and extra amounts above the rate of inflation, and has changed the locations of the thresholds. According to the State Administration, the changes in the child support formula over time are meant to follow average wage development in Denmark. However, during most years in our analysis sample, the nominal growth rate in child support obligations has been above the growth rate in average income among fathers. Appendix Figure A1 shows that the annual growth rate in the nominal normal amount was higher than the growth rate in paternal nominal average income in all years during 2000-2008 except 2005 and 2007. Appendix Table A1 depicts the child support scheme for three of our analysis years: 1999,2005 , and $2008 .^{5}$

The non-custodial father must start child support payments in the year when he no longer lives with his children (i.e., married parents who separate do not need to wait until they are divorced). He is required to make monthly payments directly to the custodial mother. In case of non-compliance, the State Administration can issue reminders, and the tax authorities can withhold non-custodial fathers' tax benefits and refunds, as well as seize their assets. ${ }^{6}$

The structure of the child support formula leads to non-linear variation in the child support obligations faced by non-custodial fathers depending on their incomes, their numbers of children, and the year: 1) in the same year, non-custodial fathers face different obligations depending on their incomes and numbers of children, 2) at the same amount of real income, non-custodial fathers face different obligations depending on the year and number of children, and 3) non-custodial fathers with the same number of children face different obligations depending on their incomes and the

\footnotetext{
${ }^{5}$ Information on annual child support guidelines comes from the State Administration. For more information, please see http://www.statsforvaltningen.dk/site.aspx? $\mathrm{p}=6404$.

${ }^{6}$ Only non-custodial fathers who are on social assistance and under a formal agreement have child support payments automatically deducted from their benefits and transferred to the mothers by the municipality government. As described in Section 4, our analysis sample consists of relatively higher-income fathers who are very unlikely to qualify for social assistance.
} 
year. This variation is displayed in the top panel of Figure 1, which plots the annual child support obligations in real year 2000 DKK for parents with one and two children in sub-figures (a) and (b), respectively. ${ }^{7}$

The State Administration's child support formula applies to all previously married, previously cohabiting, and never-married/non-cohabiting parents in the same way. ${ }^{8}$ However, while most parents seek government intervention in determining child support payments, not all do. According to the best data available on the formal agreement rate, 75 percent of divorced and separated parents had a formal child support agreement in $2006 .^{9}$ The rest of the parents either equally share physical custody or make informal agreements.

Parents who equally share physical custody of their children do not face child support obligations at all. Parents who opt for an informal agreement do not face enforced mandates from the government on payment amounts. However, the annually updated child support formula - which is posted both on the Internet and at the State Administration office - may serve as a guide for their voluntary payments. Custodial mothers can always seek a formal agreement if the non-custodial fathers' voluntary payments do not match the suggested amounts stated in the guidelines. Furthermore, non-custodial fathers have strong incentives to make payments: most of the child support paid up to the amount specified by the guidelines, regardless of whether it is paid under a formal agreement or is voluntary, is tax-deductible. ${ }^{10}$

In sum, while these factors encourage non-custodial fathers to follow the State Administration's guidelines, it is clear that the formula forms the basis for a majority — but not all — of the divorced and separated fathers' child support payments. However, since we cannot identify formal agreements and observe physical custody arrangements imperfectly in our data, our empirical analysis identifies the effects of government-mandated formal child support obligations on all divorced and separated parents. We discuss this issue further in Sections 4 and 5.

\footnotetext{
${ }^{7}$ In Appendix Figure A2, we display the father's separation year income in percentiles rather than levels (based on the income distribution in our entire sample of fathers). The figure shows that the first threshold in the formula occurs around the 60th-70th income percentile, depending on the year and the number of children.

${ }^{8}$ The only distinction is that among previously married couples, paternity of the ex-husband of the mother is presumed and does not need to be established. Among previously cohabiting or never-married/non-cohabiting parents, the parents can either sign a "Declaration of Care and Responsibility" form if they wish to share custody, or the father can sign an "Acknowledgement of Paternity" form if the parents do not want to share custody. If neither form is signed, then the mother is required to designate a father on the child's birth certificate, and a DNA test is ordered to confirm paternity. Almost all children have a legal father, who is obligated to make child support payments. See http://www.york.ac.uk/inst/spru/research/childsupport/denmark.pdf and Skinner et al. (2007) for more details.

${ }^{9}$ See http://www.york.ac.uk/inst/spru/research/childsupport/denmark.pdf and Skinner et al. (2007) for more details.

${ }^{10}$ The extra amount is not tax-deductible. The extra amount was introduced in 2000 and has varied from 1, 224DKK $(\$ 182)$ to $1,270 \mathrm{DKK}(\$ 189)$ per child per year during our analysis time frame. The value of the tax deduction for the normal amount results in a compensation for around one third of the payment.
} 


\section{Hypotheses and Existing Evidence}

\subsection{How Might Child Support Obligations Affect Parental Behaviors?}

This section describes the channels through which non-custodial fathers' child support obligations could affect parental behaviors after separation. ${ }^{11}$ We present a more formal theoretical framework in Appendix B, drawing on several existing models of interaction within non-intact families (e.g., Weiss and Willis, 1985; Del Boca and Flinn, 1995; Willis, 1999; Flinn, 2000; Del Boca and Ribero, 2003; Roff and Lugo-Gil, 2012).

The thought experiment behind our empirical analysis is to ask: What is the effect of a 1,000 DKK increase in a father's child support obligation, holding all else equal? We begin our analysis by studying child support payments. A father who always perfectly complies with his obligations will increase his payment one-for-one (i.e., by 1,000DKK exactly). However, a father who would have made a supplemental voluntary payment if the obligation were lower may just substitute the formal payment for his voluntary transfer, implying a less than one-for-one increase in the payment. Additionally, a father may respond to the increase in the obligation by adjusting other post-separation behaviors (as discussed next). These behavioral responses will in turn affect his subsequent obligations (and, therefore, his payments), also leading to a less than perfect correlation between obligations and payments.

Next, we ask whether increasing the child support obligation affects father-child contact. Our administrative data contain only one measure of contact - we observe whether fathers live with their children for at least some time post-separation. The predicted impact of increased obligations on father-child co-residence is theoretically ambiguous: On the one hand, since fathers who share in physical custody are not required to pay any child support, a higher obligation may incentivize father-child co-residence. On the other hand, the mother - as the potential recipient of the higher obligation - has the opposite incentive to refuse to allow father-child co-residence. ${ }^{12}$ Furthermore,

\footnotetext{
${ }^{11}$ Child support obligations, which, in theory, make separation and family formation more costly for non-custodial fathers and increase custodial mothers' bargaining power, may also influence the rates of divorce and separation among parents who are still together, as well as the rates of childbearing outside marriage and cohabitation among men and women who are not yet parents (Brown and Flinn, 2011). Other policies, such as unilateral divorce laws and joint custody reforms, which aim to affect the outcomes of families with divorced and unmarried parents, have been shown to also impact divorce and marriage rates (Stevenson and Wolfers, 2006; Wolfers, 2006; Halla, 2013). Such effects can complicate the study of outcomes among separated parents because of bias due to the treatment (in our setting, the child support obligation) being correlated with selection in or out of the sample of analysis. However, this issue is not empirically relevant in our context. As discussed in detail in Section 5, we find no relationship between child support obligations and the likelihood of parental separation in our data.

${ }^{12}$ In practice, parents can either agree on a custody arrangement or go to the court if they are unable to reach an agreement. Hence, if the mother refuses to share physical custody, the father can take the issue to court. However, prior to a reform in October 2007, which made joint legal custody the default determination (and hence made joint physical custody more likely as well), courts were likely to rule in favor of maternal sole custody. Thus, it is
} 
father-child contact may be influenced through the child quality production function. If parental financial and time investments are complements, a higher obligation will increase the return to the father's time spent with his child. If, instead, financial and time investments are substitutes, then a higher obligation may encourage the father to substitute away from time spent with his child.

We then study both parents' post-separation fertility. For a mother, an increase in the father's obligation generates a positive income shock, which may increase her demand for subsequent children (assuming that child quantity is a normal good). Analogously, an increase in the obligation represents a negative income shock for the father, which may decrease his demand for subsequent children. However, there are at least two additional channels that generate a positive effect on the father's post-separation fertility. First, since a higher obligation can reduce contact with his existing children, the father may have higher demand for additional children with new partners and more time to invest in these new offspring. Second, since the thresholds in the Danish child support step function are increasing in the number of biological children, and since the father must only make payments to existing non-custodial children, some fathers can reduce their obligations by having additional children in new unions. ${ }^{13}$

Finally, we study both parents' labor market outcomes. Fathers face heterogeneous labor supply incentives. For a father with an income below the first threshold in the child support step function, an increase in the obligation is a flat negative income shock, which should reduce demand for leisure and increase labor supply. In contrast, a father with an income above the threshold faces a type of tax on earnings. He has an incentive to lower his labor supply to reduce his earnings and avoid paying the additional child support amount. For a mother, an increase in the obligation is a positive income shock that is independent of her own earned income. As such, we may expect an increase in maternal demand for leisure and therefore a reduction in her labor supply. ${ }^{14}$

In sum, the question of parental behavioral responses to child support obligations is complex and with several theoretically ambiguous predictions; it is ultimately an empirical question. Below, reasonable to assume that, during our sample time frame of 1999-2008, mothers had substantial influence over the custody decision.

${ }^{13}$ We should also note that there are differential incentives for mothers' and fathers' subsequent fertility outside marriage and cohabitation. In particular, although a father may lower his per-child obligation by having more children, fertility within unions is more attractive than fertility out-of-wedlock/cohabitation, since he is only subject to the child support obligation for his non-custodial children. By contrast, relative to the father, a mother may have a larger incentive to have subsequent children out-of-wedlock/cohabitation as receipt of a higher payment for her existing children may increase her expectation of child support payments associated with subsequent offspring from new partners. See Kim et al. (2015) for more discussion of the relationship between child support and maternal non-marital fertility.

${ }^{14}$ Maternal labor supply may also be affected through impacts on father-child co-residence and fertility. For example, if fathers are more likely to reside with their children, then mothers may have more time available to work. By contrast, if mothers have more children post-separation, then they may have a higher incentive to stay home. 
we review the existing evidence on this question, and then proceed to describe our own analysis.

\subsection{Existing Evidence on Child Support}

There are two strands of existing literature on issues related to child support, both focused on the U.S. setting. One strand has used a structural model approach to directly estimate parameters of utility functions among separated parents (see, e.g., Del Boca and Flinn, 1995; Flinn, 2000; Del Boca and Ribero, 2003; Brown and Flinn, 2011; Roff and Lugo-Gil, 2012; Tartari, 2014). This approach is useful for generating predictions about the impacts of various policy counterfactuals (e.g., perfect institutional enforcement of child support obligations versus weak enforcement). As with all such structural estimations, however, functional form assumptions and concerns about endogeneity present some limitations.

We take a complementary approach by using quasi-exogenous variation in an existing policy and studying the reduced-form impacts of child support obligations on a wide range of parental behaviors. While our results cannot directly speak to parental preferences or overall welfare, our analysis instead focuses on producing causal estimates.

We thus more directly contribute to the strand of existing literature, which uses variation across U.S. states in child support enforcement spending or the implementation of specific policies (such as automatic wage withholding) to identify their effects (for an overview, see: Garfinkel et al., 1998; Del Boca, 2003; Lerman and Sorenson, 2003; Pirog and Ziol-Guest, 2006; Cancian et al., 2011; Huang and Han, 2012). Several such studies have shown that these factors are correlated with higher child support payments (Sorensen and Halpern, 1999; Freeman and Waldfogel, 2001; Sorensen and Olivier, 2002; Cancian et al., 2007), and have varied effects on non-mandated forms of involvement (Argys and Peters, 2001; Peters et al., 2004; Nepomnyaschy, 2007; Nepomnyaschy and Garfinkel, 2010; Gunter, 2013). ${ }^{15}$ The evidence on paternal labor supply is also mixed: Freeman and Waldfogel (1998) find no correlation between child support enforcement and fathers' work behavior, while Holzer et al. (2005) and Cancian et al. (2013) show a negative relationship between child support mandates and paternal formal labor supply. With regard to family formation, there is evidence that greater child support enforcement is negatively correlated with overall non-marital fertility rates, possibly implying that a deterrence effect on men may dominate the opposite effect on women (Case, 1998; Huang, 2002; Plotnick et al., 2004; Aizer and McLanahan, 2006).

\footnotetext{
${ }^{15}$ In particular, Argys and Peters (2001), Peters et al. (2004), and Nepomnyaschy (2007) all show that child support enforcement and payments are correlated with increased father-child contact (i.e., formal payments and contact are complements); Nepomnyaschy and Garfinkel (2010) find evidence of substitution between formal and voluntary payments; Gunter (2013) shows that formal payments and in-kind transfers may be substitutes as well.
} 
On the whole, the current literature has not yet painted a complete picture of how child support obligations affect parental behavior. Moreover, existing studies may be limited in their ability to establish causal relationships as child support enforcement spending and the timing of policy implementation may be correlated with other state time-varying factors that could affect the outcomes of interest (e.g., local labor market conditions, other welfare programs, changes to population demographics, etc.). Additionally, by relying on self-reported income in survey data, most of the existing work does not match fathers to their actual child support obligations.

Most recently, four papers have used proprietary data from Wisconsin to study the impacts of child support on parental employment, cohabitation, and new partner fertility. In the first paper, Cancian et al. (2013) exploit the fact that birthing costs are charged to unmarried fathers as child support when their children's births are covered by Medicaid. Using variation in birthing costs across 23 counties, they show that higher child support debt is associated with lower subsequent earnings among low-income fathers. The other three studies use data from a small randomized experiment conducted on single mothers in Wisconsin's Temporary Assistance for Needy Families (TANF) program: Relative to the control group, mothers who received higher child support payments in this experiment were less likely to cohabit with new partners (Cancian and Meyer, 2014), more likely to have a subsequent non-marital birth with a new partner (Kim et al., 2015), and no more or less likely to work (Cuesta and Cancian, 2015).

Our work builds on this literature by applying a new identification strategy and using administrative population-level data to lend causal estimates of the effects of child support obligations on a comprehensive set of parental behavioral outcomes.

\section{Data}

We use administrative data on all children born in Denmark over 1985-2008, their siblings and their parents. For each year the parent resides in Denmark, we observe his/her annual income from different sources, cohabitation and marital status, labor market behavior (employment, labor force status, and annual wages), and educational attainment, as well as demographics such as exact date of birth and country of origin.

Administrative data has clear advantages over survey data - we can rely on accurately measured key variables such as income and family structure, and observe outcomes for a large sample of separated parents. At the same time, administrative data has its drawbacks. For example, we do not observe whether parents have formal or informal child support agreements, fathers' visits with their non-custodial children, or fathers' in-kind transfers and non-monetary gifts to their children. 
We discuss these issues in Section 5, and shed some light on these variables using supplemental survey data.

Analysis Sample To construct our analysis sample, we begin with all fathers who are observed in the register data in every year over 1998-2010 and who either (i) were married to or cohabiting with their oldest children's mothers at childbirth (or in 1998 for oldest children born before), or (ii) had a first child between 1999 and 2008 while not married to or cohabiting with the child's mother. We define the father's "separation year" as the year in which the father either no longer resides with his oldest child's mother or has a first child while not living with the child's mother. As child support guidelines prior to 1999 did not exhibit as much variation with respect to income and were often not enforced, we limit to the 124, 114 fathers with separation years between 1999 and $2008 .^{16}$ We choose 2008 as the final separation year to allow for at least three years of post-separation observations in the data.

Finally, we limit the sample to fathers who had either one or two children aged less than 18 at the time of separation and who had annual separation year incomes in a 100,000DKK window surrounding the range of the first three thresholds in the child support schedule, where much of the variation occurs (between $175,000 \mathrm{DKK} / \$ 25,991$ and 505,000DKK/\$75,004). ${ }^{17}$ These restrictions create a sample of 73,303 fathers linked to their children and their children's mothers. As we describe in detail in Section 5, our analysis is cross-sectional, and thus uses one observation per father. ${ }^{18}$

Outcomes We consider four sets of outcomes. First, we study fathers' child support payments. The administrative data contain tax-deductible annual payments made by non-custodial fathers that are reported to the tax authorities. Thus we observe all payments made above the non-taxdeductible extra amount. Unfortunately, as noted above, our data do not have information on whether the payments are made under formal agreements or voluntarily.

\footnotetext{
${ }^{16}$ The information that the child support guidelines were not as strictly enforced before 1999 comes from personal communication with the State Administration. There was no specific reform; the tightening of rules likely stemmed from internal administrative changes within the agency. Since parents are more likely to be responsive to child support obligations when they are actually enforced, we only exploit variation in child support guidelines from 1999 onwards.

${ }^{17}$ We drop fathers with more than two children at the time of separation because they constitute a relatively small fraction of the sample $(10 \%)$ and experience much of the child support formula variation at higher income levels where the data contain fewer observations.

${ }^{18}$ The 73,303 observations represent unique fathers who are linked to their oldest children's mothers. However, mothers can appear multiple times in these data as they can have multiple first births with different partners from whom they separate. When we analyze mothers' outcomes, we only consider their first separation spells and are left with 71,575 unique mother observations.
} 
Second, to measure paternal physical custody, we study father-child co-residence in any year post-separation. This measure is imperfect because we can only observe one residence address per individual per year in our data. Thus, this measure includes both joint and sole-father physical custody arrangements, but underestimates joint custody because it does not capture joint custody arrangements in which the child is registered at the mother's home in all years post-separation.

Third, we study both parents' post-separation fertility. Since we have the universe of birth records through 2010, we are able to capture this outcome very accurately in our data.

Fourth, we examine both parents' labor market behavior, using information on their labor force participation, earnings, and take-up of programs such as disability insurance and early retirement.

\section{Empirical Methods}

We are interested in the effects of fathers' child support obligations on parental behaviors after separation. Consider a model of the form:

$$
Y_{i}^{P O S T}=\pi_{0}+\pi_{1} \text { AvgOblig } g_{i}+\kappa^{\prime} X_{i}+u_{i}
$$

for each father $i . Y_{i}^{P O S T}$ is an outcome of interest measured post-separation, such as the father's average annual child support payment. $\operatorname{AvgOblig}_{i}$ is the father's average child support obligation during the time of separation, $X_{i}$ is a vector of observable parental characteristics (such as education and income), and $u_{i}$ is the error term.

The primary concern with estimating equation (1) using ordinary least squares is that unobserved omitted variables (i.e., those contained in $u_{i}$ ) are correlated both with the father's child support obligation and with parental outcomes. For example, in the U.S., child support obligations are often assigned in courts. Although a judge is generally required to follow his state's child support guidelines, he may also take into account information about the parents that is unobservable to the researcher (e.g., how much conflict the parents have, how close the father is to the child, etc.) when setting the father's obligation. These characteristics of the family may in turn be correlated with parental behavior post-separation - for instance, a judge may assign a higher child support obligation to a father who seems closer to his non-custodial child, and this father may be less likely to start a new family after separation.

Using Variation from the Danish Child Support Guidelines The Danish context presents a unique opportunity to address these endogeneity concerns. As we described in detail in Section 
2, in Denmark, child support obligations are determined entirely according to a formula set by a central government agency, and not through the court system. A father's obligation is a non-linear function of his income and number of children, and this function changes in every year during our analysis time frame.

Since income thresholds in the child support formula induce discontinuities in obligations, a regression discontinuity $(\mathrm{RD})$ design may seem like the natural estimation strategy. However, there are several issues with implementing an RD in this setting. First, the thresholds are relatively close together in the annual income distribution (for example, in some cases, the thresholds are just 5,000DKK (\$742) apart), meaning that there are not enough observations immediately surrounding each threshold to implement an RD in practice. Second, the locations of the thresholds change every year. Thus, a father's income might place him on one side of a threshold in one year and on the other side in another year (even if he does not change his income). Note that we do not study behavioral responses to the year-to-year changes in child support obligations within fathers in a panel data framework, as these responses may take a longer time to materialize. Instead, we study the effects of child support obligations averaged over multiple years post-separation and compare cross-sectionally across fathers who face different average obligations. The annually changing thresholds therefore make it difficult to create a uniform $\mathrm{RD}$ treatment variable in the average obligation (in other words, is a father who is just above a threshold in year 1 and just below a threshold in year 2 in the "above" or "below" group?). Third, the fact that there are multiple thresholds in each year and for each number of children makes it challenging to center the observations around any particular threshold.

Thus, instead of estimating an RD, we exploit the full scope of variation in the child support formula by comparing across fathers who have different incomes, different numbers of children, and different separation years, while controlling flexibly for the main effects and double interactions of income, number of children, and year. To implement this empirical design, we first use the child support guidelines to calculate each father's annual child support obligation based on his income and number of children aged less than 18 in each year post-separation observed in our data. For example, for fathers who separate in 2005, we calculate child support obligations for each year over 2005-2010. We then calculate the average annual obligation for each father over the time of separation.

Importantly, we calculate child support obligations for all divorced and separated fathers in our sample. As we explained in Section 4, we do not have information on formal agreements and we measure joint physical custody imperfectly. Consequently, we cannot limit our analysis only 
to parents who have formal child support agreements. However, even if we were able make this sample selection, we believe that doing so would be problematic. Child support obligations may impact decisions about formal agreements and custody arrangements, meaning that selecting the sample on these potentially endogenous variables would create biased estimates.

Consider now the following specification:

$$
\begin{aligned}
& Y_{i t k}^{P O S T}=\theta_{0}+\theta_{1}\left[\frac{1}{T+1} \sum_{j=0}^{T} g_{t+j}\left(I_{t+j}, K i d s_{k, t+j}\right)\right]+\lambda^{\prime} X_{i t}+\sigma_{t}+f\left(I_{i t}, I_{i, t+1}, \ldots, I_{i, t+T}\right)+\rho_{k t} \\
& +\sum_{j=1}^{T} \rho_{k, t+j}+\sigma_{t} \times f\left(I_{i t}, I_{i, t+1}, \ldots, I_{i, t+T}\right)+\rho_{k t} \times f\left(I_{i t}, I_{i, t+1}, \ldots, I_{i, t+T}\right)+\sigma_{t} \times \rho_{k t}+\varepsilon_{i t k}
\end{aligned}
$$

for each father $i$ who separated from his oldest child's mother in year $t$, with $k$ number of children aged less than 18, and with $T$ total years observed post-separation in the data. $Y_{i t k}^{P O S T}$ is an outcome of interest measured post-separation. $\frac{1}{T+1} \sum_{j=0}^{T} g_{t+j}\left(I_{t+j}, K i d s_{k, t+j}\right)$ is the father's average annual child support obligation in thousands of real year 2000 DKK during the time of separation based on the child support formula, $g(\cdot)_{t+j}$, which varies in every year post-separation and depends on the father's income, $I_{t+j}$, and total number of children, $K i d s_{k, t+j}$.

The vector $X_{i t}$ includes controls for a variety of family characteristics measured in the year of separation: father's age and age squared, dummies for the father's education (less than high school, high school, vocational/short-term higher education, college/university, and missing), an indicator for the father being born in western Europe, mother's age and age squared, dummies for the mother's education (less than high school, high school, vocational/short-term higher education, college/university, and missing), an indicator for the mother being born in western Europe, mother's total income in year 2000 DKK, oldest child's age and age squared, youngest child's age and age squared, an indicator for the oldest child being male, an indicator for the youngest child being male, and indicators for original parental relationship status (married, cohabiting, never-married/noncohabiting). $\sigma_{t}$ are fixed effects for the year of separation, $\rho_{k t}$ are fixed effects for the father's number of children under age 18 in the year of separation, $\sum_{j=1}^{T} \rho_{k, t+j}$ is a set of fixed effects for the father's number of children still under 18 in each year after separation, and $f\left(I_{i t}, I_{i, t+1}, \ldots, I_{i, t+T}\right)$ is a flexible function of the father's real gross income in each year post-separation.

Since equation (2) controls flexibly for the three determinants of child support obligationsfather's income, number of children, and the year of separation - the effects of child support obligations are identified off the non-linearities in and annual changes to the child support guidelines that generate differences in average obligations for fathers who (i) have the same income and year 
of separation, (ii) have the same income and number of children, or (iii) have the same number of children and year of separation.

Yet an important concern remains. The key treatment variable, $\frac{1}{T+1} \sum_{j=0}^{T} g_{t+j}\left(I_{t+j}, K i d s_{k, t+j}\right)$, is calculated using the father's income and number of children in each year after separation. However, post-separation changes to the father's income and number of children may occur in response to the child support obligations and are thus potentially endogenous.

Simulated IV Method To deal with this issue, we follow the simulated IV approach (Dahl and Lochner, 2012; Chetty et al., 2011; Brown et al., 2014; Milligan and Stabile, 2011). For each father, we calculate a predicted obligation in each year post-separation using his gross income and number of children at the time of separation. These predicted obligations account for the father's children aging out of child support by turning 18, but do not take into account any new children that he has with subsequent partners or any changes in the father's income post-separation. As such, the variation in predicted obligations comes only from variation in what the father would have to pay based on changes in the formula, holding constant any possible behavioral responses. We calculate the average predicted obligation over the time of separation, and use this predicted measure to instrument for the actual average obligation. The first stage regression takes the form of:

$$
\begin{gathered}
\frac{1}{T+1} \sum_{j=0}^{T} g_{t+j}\left(I_{t+j}, K i d s_{k, t+j}\right)=\eta_{0}+\eta_{1}\left[\frac{1}{T+1} \sum_{j=0}^{T} g_{t+j}\left(I_{t}, \text { OrigKids } s_{k, t+j}\right)\right]+\zeta^{\prime} X_{i t}+\delta_{t}+f\left(I_{i t}\right)+\alpha_{k t} \\
+\sum_{j=1}^{T} \alpha_{k, t+j}+\delta_{t} \times f\left(I_{i t}\right)+\alpha_{k t} \times f\left(I_{i t}\right)+\delta_{t} \times \alpha_{k t}+e_{i t k}
\end{gathered}
$$

where $\frac{1}{T+1} \sum_{j=0}^{T} g_{t+j}\left(I_{t}\right.$, OrigKids $\left.s_{k, t+j}\right)$ is the average predicted obligation, calculated using the father's separation year income, $I_{t}$, and his number of "original" children (i.e., those that he had at the time of separation) that are still under 18 in every year, OrigKids $s_{k, t+j}$. The IV model is:

$$
\begin{aligned}
Y_{i t k}^{P O S T}= & \beta_{0}+\beta_{1}\left[\frac{1}{T+1} \sum_{j=0}^{T} g_{t+j}\left(I_{t+j}, K i d s_{k, t+j}\right)\right]+\gamma^{\prime} X_{i t}+\delta_{t}+f\left(I_{i t}\right)+\alpha_{k t} \\
& +\sum_{j=1}^{T} \alpha_{k, t+j}+\delta_{t} \times f\left(I_{i t}\right)+\alpha_{k t} \times f\left(I_{i t}\right)+\delta_{t} \times \alpha_{k t}+\epsilon_{i t k}
\end{aligned}
$$

We include fixed effects for the year of separation, $\delta_{t}$, and fixed effects for the number of children in the year of separation, $\alpha_{k t}$. We also include a set of indicators for the father's number of children still under age 18 in each year post-separation (but not including any new children born after 
separation), denoted by $\sum_{j=1}^{T} \alpha_{k, t+j}$. The model includes a flexible function of the father's real gross income in the year of separation $f\left(I_{i t}\right)$, and all of the double interactions between income, number of children, and the year of separation. The key coefficient of interest is $\beta_{1}$, which measures the effect of a $1,000 \mathrm{DKK}$ increase in the average annual child support obligation on the outcome of interest.

The bottom panel of Figure 1 plots the average predicted obligation, $\frac{1}{T+1} \sum_{j=0}^{T} g_{t+j}\left(I_{t}\right.$, OrigKids $\left.s_{k, t+j}\right)$, by year of separation and father's income, for one- and two-child families in sub-figures (c) and (d), respectively. The figure shows non-linear variation in the average predicted obligation across fathers with different separation year incomes, years of separation, and numbers of children. Most noticeably, there is a "kink" in the relationship between the average predicted obligation and the father's separation year income in each year. This "kink" arises from the non-linearity in the child support formula around the first income threshold. In some specifications, we limit our sample to fathers with separation year incomes within a small window around the first threshold to exploit this non-linearity more explicitly.

Figure 2 depicts the identifying variation in equations (3) and (4) more clearly. We first regress the average predicted obligations on fixed effects for the year of separation, number of children, and 20,000 DKK (approximately $\$ 3,006$ ) bins of the father's separation year income, and the double interactions of these three variables. We then calculate the residuals, and scatter all possible residuals within each 20,000DKK income bin separately by families with one child (in blue circles) and two children (in red triangles) in sub-figures (a) and (b), respectively. We make similar scatterplots of average predicted obligation residuals within each separation year in sub-figures (c) and (d). In other words, sub-figures (a) and (b) show all of the variation in average predicted obligations that remains within each 20,000DKK income bin for one- and two-child families separately (after controlling for all of the fixed effects and double interactions), while sub-figures (c) and (d) show this variation within each separation year. Our preferred empirical specification, which uses indicators for 20,000DKK income bins as the function $f\left(I_{i t}\right)$ as well as dummies for the year of separation and number of children and their double interactions, essentially compares vertically across fathers who are represented by the different blue circles and red triangles in these figures.

Finally, while our baseline estimates represent the effects of average annual obligations over all the years of separation, we also investigate the timing of their impacts more closely. For these analyses, we estimate the following IV models:

$$
Y_{i k, t+\tau+1}=\beta_{0}+\beta_{1}\left[\frac{1}{\tau} \sum_{j=0}^{\tau} g_{t+j}\left(I_{t+j}, K i d s_{k, t+j}\right)\right]+\gamma^{\prime} X_{i t}+\delta_{t}+f\left(I_{i t}\right)+\alpha_{k t}
$$




$$
+\sum_{j=1}^{\tau} \alpha_{k, t+j}+\delta_{t} \times f\left(I_{i t}\right)+\alpha_{k t} \times f\left(I_{i t}\right)+\delta_{t} \times \alpha_{k t}+\epsilon_{i k, t+\tau+1}
$$

where $\tau$ ranges between 1 and 5. Thus, for years $\tau \in[1,5]$ — the first five years of separation-we study the relationship between outcomes measured in year $t+\tau+1$ and $\left.\frac{1}{\tau} \sum_{j=0}^{\tau} g_{t+j} \widehat{\left(I_{t+j}\right.}, K i d s_{k, t+j}\right)$, which denotes obligations averaged over the preceding post-separation years only (i.e., years $t$ to $t+\tau)$

Identifying Assumption The identifying assumption for the estimation of equations (3), (4), and (5) is that - conditional on the father's year of separation, and his income and number of children in that year - there are no omitted variables that systematically covary with both predicted child support obligations and parental post-separation behaviors. The separation year fixed effects control for any overall trends in parental outcomes over the time of our analysis, and absorb any effects of national policies that may have been implemented in any given year. ${ }^{19}$ Fixed effects for the number of children and their interactions with separation year fixed effects control for the fact that one- and two-child families may be different and may have different trends over time. Finally, for $f\left(I_{i t}\right)$, we use different order polynomials as well as non-parametric specifications with indicators for small income bins to control for a flexible relationship between the father's separation year income and the outcomes of interest. We allow for this relationship to be different over time and across families with different numbers of children by including interactions between $f\left(I_{i t}\right)$ and the fixed effects for separation year and number of children.

There are several remaining possible threats to identification. First, our sample is limited to parents who have divorced or separated. If separation decisions are made in response to (anticipated) child support obligations, then our analysis could be subject to sample selection bias. We examine the relationship between child support obligations and the likelihood of parental separation in Table 1. For these regressions, our sample contains all fathers observed over 1999-2010 (i.e., we do not limit to separated fathers). ${ }^{20}$ We only keep father-year observations until the year of separation (if it occurs). Our outcome of interest is an indicator for parents separating, divorcing, or having an out-of-wedlock/cohabitation birth. We regress this outcome on the child support obligation that a father would face in that year (calculated based on his income and number of children), with a

\footnotetext{
${ }^{19}$ Additionally, the year of separation fixed effects control for differences in the length of separation time, $T$, observed in our data.

${ }^{20}$ We do, however, make the same sample restrictions on income, number of children, and years of observation as before: We limit to fathers who were either married to or cohabiting with their oldest children's mothers at the time of childbirth (or in 1998 for oldest children born before), or who had a first child between 1999 and 2010 while not cohabiting with their child's mother. We also only keep father-year observations with nominal incomes between 175,000 and 505,000DKK and with either one or two children aged less than 18.
} 
full set of fixed effects and interactions for the number of children, year, and different functions of the father's income. ${ }^{21}$ The results show that child support obligations are not systematically correlated with the likelihood of parental separation. While there are some significant coefficients in specifications using lower-order polynomial functions in father's income, they have opposite signs. Moreover, in our preferred specification that includes indicators for 20,000DKK bins of father's income, we find no statistically significant relationship. We thus conclude that, in our data, parents do not seem to make their separation decisions in anticipation of child support obligations.

Second, while we inherently cannot test whether the variation in predicted child support obligations is correlated with omitted unobservable factors, we can check whether it is related to any observable parental characteristics that are not used in the child support formula. For these regressions, we focus on our main analysis sample and estimate reduced-form versions of equation (4), omitting the controls in vector $X_{i t}$ and with the following outcomes (measured in the year of separation): father's age, mother's age, indicators for the father's and mother's education levels (university, vocational/short-term higher education, high school only), and mother's income. Table 2 and Appendix Table A2 present results from specifications that use indicators for 20,000DKK bins and 4th order polynomials as the father's income functions $f\left(I_{i t}\right)$, respectively. Predicted obligations have no statistically significant relationships with any of the variables that we consider.

A third concern for our identification strategy is that fathers may respond to future child support obligations by changing their incomes before separation. Such anticipatory behavior would make our instrument-based on the father's separation year income-potentially endogenous. Since the child support formula is a fairly complex non-linear function of the father's income that is changed in every year, most fathers are unlikely to be able to predict their average post-separation obligations very accurately. Nevertheless, we evaluate the plausibility of this issue in two ways in Section 6: (i) we show that our results are similar when we predict child support obligations using the father's income in the year before separation, and (ii) we provide evidence that fathers' labor supply behavior in the years before separation is uncorrelated with future obligations.

Summary Statistics In our main analysis sample, real average annual child support obligations have ranged between $783 \mathrm{DKK}(\$ 116)$ and $42,608 \mathrm{DKK}(\$ 6,328)$ in year $2000 \mathrm{DKK}$, representing between 0.4 and 26 percent of fathers' annual gross incomes. ${ }^{22}$ The median real average annual

\footnotetext{
${ }^{21}$ In column 5, when we include indicators for 20,000DKK bins in the father's income, for computational feasibility, we collapse the data into cells according to the interactions these father income bins, years 1999-2010, and the number of children. The regression in column 5 is weighted by the number of observations in each cell and has standard errors clustered on the cell level.

${ }^{22}$ The average annual obligation can be lower than the annual obligation depicted in Figures $1 \mathrm{a}$ and $1 \mathrm{~b}$ because we account for children aging out of child support by turning 18 . Thus, some fathers have a positive obligation in
} 
obligation is $14,620 \mathrm{DKK}(\$ 2,171)$.

Appendix Table A3 provides summary statistics on other selected variables in our data. Column 1 reports information on all fathers in our sample, while columns 2-4 split the sample by parental relationship status - previously married, previously cohabiting, and never-married/non-cohabiting, respectively. For comparison, column 5 reports summary statistics for all parents of children born in 1985-2010 who appear in the register data over 1998-2010. ${ }^{23}$ The average separation year real gross incomes for fathers and mothers in our sample are 286,300DKK and 205,600DKK, respectively, which are slightly lower than the corresponding average real incomes of 307,700DKK and 211,000DKK for all Danish fathers and mothers during this time period. The parents in our sample are also less likely to have a university education than parents in the general population.

Appendix Table A3 also presents further information on the average annual child support obligations that we calculate and the payments we observe. Here, we report the predicted and actual annual tax-deductible obligations (i.e., obligations net of the extra amount) so that we can more accurately compare them to the tax-deductible payments we see in our data. For all fathers in our sample over the time of separation, the average annual obligation net of the extra amount is $17,500 \mathrm{DKK}$, while the average annual payment net of the extra amount is $9,211 \mathrm{DKK}$.

Differences Between Obligations and Payments We investigate the discrepancy between obligations and payments further in Appendix Table A4. Fathers pay about 53 percent of their taxdeductible obligation. This gap is partially driven by the 19 percent of sample fathers who make zero child support payments post-separation. These "non-payers" are likely comprised of two groups: (i) fathers without formal agreements (including those who have full or joint physical custody of their children), and (ii) fathers who are completely non-compliant with their obligations. ${ }^{24}$

While we inherently cannot distinguish between these two groups in our data, we provide some indirect evidence suggesting that joint and sole-father physical custody arrangements likely play a large role in explaining the zeros. As described in more detail in Appendix C, we link our administrative data to survey data with parent-reported information on custody arrangements. Since the surveys were only conducted in selected years and have small sample sizes, we do not use these data for our main analysis and instead just examine them descriptively. We show that survey

the first few years post-separation and zero obligation in the subsequent years because their children have aged out, leading to a small average amount.

${ }^{23}$ There is no year of separation for these families; the statistics reported are averages over 1998-2010.

${ }^{24} \mathrm{~A}$ third possibility in our data is that some fathers make child support payments but do not report them to the tax authorities. However, given that all payments above the extra amount are tax deductible, this seems unlikely as fathers have a strong incentive to report these transfers. 
reports of joint and sole-father physical custody arrangements coincide with lower average postseparation child support payments and with a higher prevalence of zero payments by fathers. The survey data also show that about 22 percent of fathers have either joint or sole physical custody, which is close to the percentage of "non-payers" that we observe in our sample. ${ }^{25}$

While the "non-payers" account for some of the gap between average obligations and payments, they do not explain all of it. Among those who pay a strictly positive amount, fathers on average pay 66 percent of their tax-deductible obligation. Seventy-two percent of the fathers in the sample pay more than zero but less than their obligation, while 9 percent pay the amount of the obligation or more. The "under-payment" likely results the fact that we observe both mandated and voluntary payments in one variable where voluntary payments do not need to follow any guidelines, as well as possibly from imperfect compliance. "Over-payment" is most common among previously married parents and is likely driven by voluntary payments.

Finally, it may be that some of the fathers whom we observe "under-paying" give supplemental gifts or in-kind transfers to their children that are not recorded in our administrative data. The survey has some information on these types of non-pecuniary transfers. For example, about 18 percent of mothers report that the father has bought some winter clothes for his child, while around 4 percent report that the father has paid for childcare. ${ }^{26}$ These numbers suggest that large in-kind transfers are not pervasive in our analysis population.

\section{Results}

\subsection{First Stage Results}

Before presenting the results from our IV regressions - where we report the first stage coefficient and corresponding $F$-statistic in all tables - we briefly discuss the strength of the first stage relationship between predicted and actual obligations, its independence of the chosen functional form, and the sources of variation that drive it.

In Appendix Table A5, we report results from estimating the first stage regression of predicted obligations on actual obligations (equation (3)), controlling for different functions of the father's real separation year income: linear (column 1), quadratic (column 2), cubic (column 3), quartic (column 4), and indicators for 20,000DKK bins (column 5). Across all specifications, the first

\footnotetext{
${ }^{25}$ We also explored heterogeneity in joint custody rates by family characteristics. Joint custody is relatively more prevalent among parents of children who were older at the time of separation and parents from higher socio-economic status groups (those with more than a high school education and with incomes above the median in our sample).

${ }^{26}$ These figures come from the 1999 wave of the Danish longitudinal survey of children (DALSC) where children of interviewed mothers were three years old. See Appendix C for details.
} 
stage is very strong (the $F$-statistic ranges between 1,972 and 5,190). Our preferred specification in column 5 indicates that each $1,000 \mathrm{DKK}$ increase in the average predicted obligation is associated with a $840 \mathrm{DKK}$ increase in the actual average obligation.

Appendix Figure A3 illustrates the variation that drives the first stage relationship. Appendix Figure A3a plots coefficients and 95\% confidence intervals from first stage regressions estimated separately by year of separation, using only the variation in average predicted obligations across father's income and number of children. Here, we see that the first stage is somewhat stronger in years 2000-2002 than in the other years, although all coefficients are positive, statistically significant, and with overlapping confidence intervals. Appendix Figure A3b presents coefficients from first stage regressions estimated separately by each 20,000 DKK income bin, using only the variation across years of separation and number of children. The coefficients across income bins are quite similar and almost all statistically significant, except for the three highest income bins where we have few observations. Appendix Figure A3c shows coefficients from first stage regressions estimated separately for one- and two-child families, using only the variation across father's income and years of separation. The first stage relationship is stronger for one- than two-child families, although both coefficients are above 0.7 and statistically significant. Overall, although there are some differences across coefficients, these results suggest that the identification comes from all three sources of variation (separation year income, year of separation, and number of children).

\subsection{Child Support Payments and Father-Child Co-Residence}

We first study how child support obligations affect fathers' child support payments and father-child co-residence. Table 3 presents results from estimating equation (4) using two-stage least-squares (2SLS) for the following outcomes measured post-separation: father's average annual child support payment, an indicator for the father's average child support payment being greater than his average obligation, an indicator for the father paying zero child support in at least one year, and an indicator for the father living with his oldest child in at least one year. In these models, the $f\left(I_{i t}\right)$ function is captured by indicators for 20,000DKK bins in the father's real separation year income.

Column 1 shows that a 1,000DKK increase in the average annual child support obligation is associated with a 506DKK increase in the average annual payment. In Section 3, we hypothesized that the lack of a one-for-one correlation may be in part driven by supplemental voluntary payments. Indeed, in column 2, we show that a higher obligation reduces the likelihood that a father pays more than what he is obligated to pay, suggesting that mandated payments may be partially substituting for voluntary payments that fathers would have otherwise made. Additionally, the 
less than perfect correlation between obligations and payments may be due to the other parental behavioral responses, which we analyze below.

Column 3 shows that fathers facing higher obligations are less likely to pay zero child support in at least one post-separation year. This effect seems to be driven by a reduction in paternal physical custody (column 4): a 1,000DKK increase in the average obligation is associated with a 2.1 percent decrease in father-child co-residence post-separation.

As discussed in Section 3, there are two opposing forces on paternal physical custody. On the one hand, relative to fathers with lower child support obligations, fathers facing larger obligations may have a greater incentive to avoid paying them by sharing in physical custody. On the other hand, mothers have the opposite incentive to receive the higher payments by making sure that fathers do not share in physical custody. Additionally, fathers with higher obligations may be more likely to substitute away from other forms of non-pecuniary involvement with their children. Our empirical results suggest that the latter forces dominate in our sample, leading to a negative relationship between obligations and paternal physical custody rates.

In Appendix Figure A4, we investigate the timing of the paternal physical custody effect during the length of separation. This figure presents the coefficients and 95\% confidence intervals from five separate IV regressions of equation (5). For years $x \in[1,5]$ 一 the first five years of separation displayed on the x-axis - each regression uses an indicator for the father living with his oldest child in year $x+1$ post-separation as the dependent variable and the average annual obligation over the preceding post-separation years $(0$ to $x)$ as the explanatory variable. The results suggest that the magnitude of the reduction in the paternal physical custody rate is increasing over the length of separation, although the confidence intervals are wide enough such that we cannot reject that all five coefficients are equal.

In sum, these results suggest that, while government-mandated child support obligations are moderately effective in increasing fathers' monetary payments to children, they may also crowd-out other forms of father involvement, such as voluntary payments and father-child co-residence.

\subsection{Parental Subsequent Family Formation}

Next, we proceed to examine parental fertility post-separation. Tables 4 and 5 present the 2SLS results for family formation outcomes for the mothers and fathers, respectively.

We find that, for both parents, higher child support obligations lead to increased subsequent fertility with new partners. In particular, the first columns in both tables show that each 1,000DKK increase in the child support obligation is associated with 3.2 and 3.7 percent increases in the 
likelihoods of mothers and fathers having more children, respectively. Notably, as seen in columns 2 to 4 , fathers increase their fertility only within marriage or cohabitation, while mothers increase their fertility both in and outside these unions.

We also explore the timing of the fertility effects for mothers and fathers in Appendix Figures A5 and A6, respectively. For fathers, fertility increases materialize after 4 to 5 years post-separation, while for mothers, the positive impacts on fertility are present 3 and 5 years after separation.

As we discussed in Section 3, the positive impact on maternal fertility is consistent with higher child support obligations generating greater income effects. The magnitude of our estimate - a 3.2 percent increase for every $1,000 \mathrm{DKK}$ increase in obligations - is within the bounds of estimates in the literature. In fact, Kim et al. (2015) - in the only existing study on the causal effect of child support receipt on maternal (non-marital) fertility in Wisconsin - find a $4 \%$ increase in fertility for every 1,000 DKK in payments (after converting from U.S. dollars to Danish krones). The broader income-fertility literature delivers comparable estimates as well. For example, Milligan (2005) finds a 3.4 percent increase in fertility associated with a 1,000DKK increase in tax benefits in Quebec. In France, the relevant relationship is a 4 percent increase in fertility for every 1,000DKK increase in benefits (Laroque and Salanié, 2008). In the UK, there is a slightly more modest 2 percent increase in fertility for every $1,000 \mathrm{DKK}$ increase in welfare benefits stemming from a 1999 reform (Brewer et al., 2012). ${ }^{27}$

For fathers, the positive relationship between obligations and fertility is consistent with two incentives. First, we found above that higher obligations are associated with a reduced incidence of father-child co-residence. Thus, fathers who are facing higher obligations may have less attachment to their existing children and more demand for new offspring with new partners. Second, fathers with incomes in certain ranges above the child support step function thresholds can reduce their obligations to non-custodial children by having more children within new unions. ${ }^{28}$ Column 5 of Table 5 shows that the fertility increase is driven by fathers who do not reside with their older children post-separation, consistent with the first incentive.

Finally, the fact that fathers facing larger obligations only increase fertility within marriage or

\footnotetext{
${ }^{27}$ More precisely, Kim et al. (2015) find that a $\$ 300$ (in U.S. dollars) increase in child support payments leads to a (marginally significant) $8 \%$ increase in subsequent non-marital fertility among single mothers. $\$ 300$ is approximately 2,000DKK. Milligan (2005) finds that a \$1,000 (in Canadian dollars) increase in tax benefits increases fertility by 17\%. \$1,000 Canadian dollars is approximately 5,000DKK. Laroque and Salanié (2008) find that 100 Euros per month (i.e., 1, 200 Euros per year) increase higher-parity fertility by 37\%. 1, 200 Euros is approximately 8, 954DKK. Brewer et al. (2012) find that the mean $£ 900$ increase in welfare benefits following a 1999 reform led to a $15 \%$ increase in fertility among low-income married women. $£ 900$ is approximately 8,300 DKK. The muted response in the U.K. may be in part due to an accompanying work incentive that likely reduced fertility.

${ }^{28}$ In our sample, a father who had one child at the time of separation can save up to $11,040 \mathrm{DKK}$ in annual obligations by having an additional child. The average saving is $1,973 \mathrm{DKK}$.
} 
cohabitation is consistent with them expecting higher costs of future children born outside these unions. By contrast, mothers receiving higher child support payments for current children may expect higher transfers for future children if they separate again. Thus, higher obligations are associated with increased maternal fertility both in and outside new partnerships.

\subsection{Parental Labor Market Behavior}

Finally, we analyze the effects of child support obligations on parental labor market outcomes. Table 6 presents the 2SLS results on fathers' post-separation labor market behavior. We find that, on average, higher obligations are associated with a reduction in the amount of time fathers spend in the labor force. Specifically, each 1,000DKK in the child support obligation reduces the fraction of years post-separation during which they have any positive labor income by 0.2 percent and increases the proportion of years they spend not in the labor force ("NILF") by 5 percent at the respective sample means. Columns 6 to 8 of Table 6 show that this increase is driven by transitions into disability leaves and retirements (including discretionary early retirements). ${ }^{29}$ In contrast, we find no effects on exiting the labor force to receive means-tested welfare benefits, as this transition is likely unrealistic for the majority of our (relatively higher-income) fathers. ${ }^{30}$ For mothers, we find no consistent evidence of changes to labor market behavior (see Appendix Table A6).

Since labor market outcomes are measured both before and after separation, we can test for anticipatory effects on paternal labor force participation pre-separation. In Figure 3, in addition to looking at the timing of effects post-separation, we also study whether obligations in the year of separation are correlated with paternal labor force participation in the five years before separation. We find that the coefficients in the years before separation are all very close to zero, and that the positive effect on the likelihood of the father being out of the labor force begins to materialize about 3 years following separation.

\footnotetext{
${ }^{29}$ In Denmark, individuals mainly receive disability income through the Social Disability Pension (SDP) program. SDP is granted based on several medical and social criteria, and there are three levels depending on the degree of work capacity. Eligibility for the lowest level depends on work capacity having been reduced to below half the normal level, based on an evaluation using a combination of health and social criteria. Thus, although transitioning from the labor force and into disability leave is not costless, the subjectivity in the eligibility requirements leaves room for behavioral responses on this margin that may be unrelated to changes in fathers' actual health conditions. The main retirement program in Denmark is the Old Age Pension program, for which individuals are eligible starting at age 65. The Post-Employment Wage (PEW) program is the program for early retirement, for which individuals are eligible during ages 60-64. Other eligibility requirements for the PEW include sufficient contributions to the Unemployment Insurance fund and being in the labor force at age 59. See Larsen and Pedersen (2012) for more information.

${ }^{30}$ Our estimate on labor supply is somewhat larger than what is reported in Cancian et al. (2013) - the most recent study on the relationship between child support obligations and labor supply in the U.S. - who find that a $\$ 1,000$ increase in child support debt reduces formal earnings by about 3 percent. However, Cancian et al. (2013) use a highly selected sample from Wisconsin, and further limit the analysis to low-income fathers who were working for a single employer all four quarters prior to the birth of their first child.
} 
Moreover, although our results point to higher obligations being associated with lower average paternal labor supply, they conceal important heterogeneity in responses. As we hypothesize in Section 3, the structure of the child support guidelines creates divergent labor supply incentives depending on where the father's income is located relative to the step function thresholds. To test for such differential responses, we include an interaction term with an indicator for the father's separation year income being above the first threshold in that year in Table 7. We find that fathers with separation year incomes below the first threshold actually increase their labor supply. The decline in labor force participation is driven entirely by fathers with separation year incomes above the first threshold, who have an incentive to reduce their labor supply in order to avoid paying the additional percentages of the normal amount.

Overall, as postulated in Section 3, the decline in paternal labor force participation implies that, at least for some (higher-income) fathers, child support obligations play the role of income taxes, with the substitution effect dominating the income effect. Our findings are broadly consistent with other studies on the relationship between the relative value of labor market participation and disability/retirement program take-up in the U.S., Canada, and Europe. ${ }^{31}$ Thus, our estimates point to an unintended consequence of child support mandates on public budgets: Although they may shift the burden of single-mother household support from welfare programs to non-custodial fathers, they also may pass part of this cost on to other government programs including disability insurance and early retirement.

\subsection{Heterogeneous Effects of Child Support Obligations}

Appendix Figures A7-A11 analyze heterogeneous treatment effects by exploring different sources of the identifying variation: In each of these figures for our main outcomes, the sub-figures plot coefficients and $95 \%$ confidence intervals from IV regressions that only use two sources of variation: (a) separately by year of separation, using only variation across paternal income and number of children; (b) separately by each 50,000DKK $(\$ 7,582)$ income bin, using only variation across years of separation and number of children; and (c) separately for one- and two-child families, using only the variation across father's income and years of separation. ${ }^{32}$

For average child support payments, the coefficients are almost all positive and with overlapping confidence intervals. The estimated negative effects on father-child co-residence are somewhat

\footnotetext{
${ }^{31}$ See, e.g., Black et al. (2002); Autor and Duggan (2003); Gruber (2000); Gruber and Wise (2004, 2009); Bratsberg et al. (2010); Bingley et al. (2011).

${ }^{32}$ For the IV heterogeneity analysis, we use 50,000DKK income bins instead of the baseline 20, 000DKK bins to retain slightly larger sub-group sample sizes.
} 
stronger in the middle years in our sample (early 2000s) and among lower-income fathers, although the coefficients are generally not individually statistically significant. The positive effect on paternal post-separation fertility is slightly larger in the earlier sample years, among lower-income fathers, and fathers with one child at separation. The increase in maternal post-separation fertility is noticeably larger among mothers whose children's fathers are lower-income and who only had one child at separation. While the overall effect on the father's time spent NILF is positive for most separation years and for fathers with both one and two children, the heterogeneity analysis by paternal income replicates the pattern in Table 7, with fathers in the lowest income bin decreasing their time spent NILF, and fathers in the highest income bin driving the overall positive effect. On the whole, since we lose variation and sample size when we consider these separate sub-groups, it is difficult to draw definitive conclusions from these figures. Nevertheless, just like in Appendix Figure A3, this analysis suggests that all three sources of the identifying variation-separation year income, year of separation, and number of children - contribute to the estimation of the main results.

In Appendix Table A7, we consider differences in effects between previously married, previously cohabiting, and never-married/non-cohabiting parents. For all outcomes except for the father's labor force participation, the coefficients are of the same sign between the first two groups and slightly larger in magnitude for previously married parents (see Panels A and B). However, we see differential effects on father's labor force participation - a higher obligation increases (decreases) the amount of time a father spends out of the labor force among previously married (previously cohabiting) fathers. Further exploration of this result suggests that it reflects the heterogeneity in effects on labor supply by fathers' separation year incomes (see Table 7), as previously married fathers on average have higher incomes than previously cohabiting fathers. When we consider never-married/non-cohabiting parents in Panel C, we lose a lot of power and obtain much larger standard errors. There are positive and large effects on child support payments and maternal fertility, and no statistically significant effects on any of the other outcomes in this sub-group. ${ }^{33}$

\footnotetext{
${ }^{33}$ We have also examined heterogeneous treatment effects across parents with oldest children of different genders. Across all of the outcomes that we consider, we see no meaningful (or statistically significant) differences in the behavior of parents who have boys relative to that of parents who have girls. The lack of gender differences may be surprising in light of evidence from the U.S. that parents are less likely to get divorced and unmarried fathers are more likely to acknowledge paternity when they have boys than when they have girls (Lundberg and Rose, 2003; Bedard and Deschenes, 2005; Lundberg et al., 2007; Dahl and Moretti, 2008; Almond and Rossin-Slater, 2013). However, our results suggest that, at least in Denmark, parents respond similarly to child support obligations regardless of whether they have sons or daughters.
} 


\subsection{Additional Results}

Alternative Specifications We test the robustness of our main results across different specifications in Appendix Tables A8 and A9. Appendix Table A8 considers four different polynomial functions of the father's separation year income: linear (Panel A), quadratic (Panel B), cubic (Panel C), and quartic (Panel D). Appendix Table A9 considers four alternative "bin" indicator functions of the father's separation year income: 50,000DKK bins (Panel A), 25,000DKK bins (Panel B), 15,000DKK bins (Panel C), and 10,000DKK bins (Panel D). On the whole, the coefficients across these different specifications are quite stable and mostly statistically significant. ${ }^{34}$ These robustness tests provide support for the validity of the identification strategy and the strength of the results.

Results from Narrow Window Around First Threshold As demonstrated in the bottom panel of Figure 1, there is a "kink" in the relationship between the average predicted obligation and the father's income that arises from the non-linearity in obligations at the first threshold in the child support formula in each year. We exploit this variation more explicitly by limiting our sample to fathers with separation year incomes in narrow windows surrounding this threshold. Appendix Table A10 shows results from using the following windows: 20,000DKK (Panel A), 40,000DKK (Panel B), 60,000DKK (Panel C), 80,000DKK (Panel D), and 100,000DKK (Panel E). Note that all of the sample sizes in this table are smaller than those in our baseline analysis, where we use a 100,000DKK window surrounding the first three thresholds.

Although we lose substantial power, the coefficients in Appendix Table A10 are quite similar to the main ones we report for four out of the five outcomes we consider. When we consider father NILF as an outcome, however, we find negative coefficients in Panels A-D, and a positive coefficient in Panel E, although none is statistically significant at the $5 \%$ level. We believe that this pattern reflects the treatment effect heterogeneity with respect to income relative to the first threshold that we saw in Table 7. In narrow windows around the threshold, the increase in labor supply among lower-income fathers seems to, if anything, outweigh the decrease in labor supply among higher-income fathers.

Alternative Instruments We examine the sensitivity of our results to alternative ways of predicting child support obligations in the simulated IV framework in Appendix Table A11. In Panel A, we address the concern that fathers may respond to their obligations by changing their separa-

\footnotetext{
${ }^{34}$ The only exception is that the result on paternal labor force participation is somewhat sensitive to the polynomial function in the father's separation year income, and flips in sign when we include a cubic polynomial.
} 
tion year income by presenting IV results for our main outcomes where we use the father's income measured in the year before separation to predict child support obligations. Our results are similar to the main ones described above, suggesting that endogenous income changes in the year of separation are unlikely to generate substantial biases in our analysis.

In Panel B, we use a different function of child support obligations instead of a simple average. Specifically, we calculate a weighted average, discounting obligations in each year after separation. Our instrument thus becomes:

$$
\frac{1}{\sum_{j=0}^{T} \frac{1}{(1+r)^{j}}} \sum_{j=0}^{T} \frac{1}{(1+r)^{j}} \cdot g_{t+j}\left(I_{t}, \text { OrigKids } s_{k, t+j}\right),
$$

and we use an analogous weighted average measure of the actual obligation as well. We assume a 5 percent discount rate with 2 percent inflation (i.e., $r=0.03$ ). The results with this weighted average measure are very similar to the main ones we have presented.

In Panel C, we calculate each father's average predicted obligation using the father's predicted income in each year post-separation instead of simply using the separation year income. We first regress the father's income in each year post-separation on a set of pre-determined characteristics observed in the separation year: the father's separation year income, the father's age and age squared, dummies for the father's education, and an indicator for the father being from Western Europe. We use the father's predicted income in each year after separation to calculate his average predicted obligation, which we then use to instrument for his actual average obligation. Again, we find similar coefficients to those in our baseline results.

In Panel D, we test the robustness of our results to controlling for the father's post-separation year income. While we believe this control to be endogenous, the results are largely unchanged when we include it into our models.

\subsection{Are Child Support Obligations Good or Bad for Families?}

Throughout this paper, we have documented parental behavioral responses to child support obligations. Yet an important question regarding the overall welfare of children and parents in split families remains largely unanswered. Is a higher child support obligation good or bad for these families?

To try to shed some light on this question, we first think through the implications of our behavioral results for the welfare costs and benefits associated with a 1,000DKK increase in the child support obligation. First, we find that a 1,000DKK increase in the obligation is associated 
with a 506DKK increase in the father's payment to the mother-child household. Thus, one benefit is a 506DKK increase in the mother-child household's income multiplied by the marginal utility of that household. Since the child support payment is tax-deductible for the father, this transfer entails a cost to the father of 506DKK $\times(1-\tau)$ multiplied by his marginal utility, where $\tau$ is the marginal tax rate applied to the 506DKK in income he would have kept in the absence of making the payment. There is also a loss in tax revenue of 506DKK $\times \tau .{ }^{35}$ Comparing only these benefits and costs implies the increase in the child support obligation should only be welfare-improving if the marginal utility of consumption in single-mother households is sufficiently higher than the marginal utility of consumption among fathers (i.e., if maternal income is sufficiently lower than paternal income). In our analysis sample, maternal annual income is on average $80,600 \mathrm{DKK}(\$ 12,180)$ lower than paternal annual income (see Appendix Table A3).

Second, we need to take into account paternal labor supply responses. Results in Table 6 suggest that the average effect of a $1,000 \mathrm{DKK}$ increase in the obligation is a reduction in labor supply. Given that this result is driven by higher-income fathers and that the marginal tax rate is increasing in income, there could potentially be a non-trivial loss in tax revenue. In our data, among fathers with separation year incomes above the first threshold, the difference in average post-separation incomes between those who spend all years in the labor force and those who spend at least one year out of the labor force is $351,000-278,000=73,000 \mathrm{DKK}(\$ 11,048) .{ }^{36}$ Multiplying by the relevant marginal tax rates implies an average per-father revenue loss of approximately $34,099 \mathrm{DKK}{ }^{37}$

Moreover, there are costs associated with fathers entering the DI and early retirement systems instead of working. In 2008, public expenditure on disability pensions amounted to about 16.5 billion DKK ( $\$ 2.5$ billion) in Denmark. ${ }^{38}$ Given that there were about 240,000 recipients in that year, this translates to approximately $69,000 \mathrm{DKK}(\$ 10,428)$ per recipient. ${ }^{39}$ We estimate that a $1,000 \mathrm{DKK}$ increase in obligations leads to a 0.0012 increase in DI take-up, which can be valued at

\footnotetext{
${ }^{35}$ The mother-child household does not pay taxes on the child support income it receives. Thus, the tax revenue loss is not compensated by additional tax payments from the mother-child household. Marginal tax rates in Denmark are: $0 \%$ for personal income up to $41,000 \mathrm{DKK} ; 37.48 \%$ for incomes between 41,001 and $279,800 \mathrm{DKK}$; $43.48 \%$ for incomes between 279,801 and 335,800DKK; and 59\% for incomes above 335,800DKK. See https://www.cfeeutax.org/taxation/personal-income-tax/denmark.

${ }^{36}$ By the envelope theorem, there should be no loss in the father's individual welfare from the labor supply response, assuming he is behaving optimally. The marginal cost of foregone consumption due to lower income should be equal to the marginal benefit of increased leisure.

${ }^{37}$ The loss in average per-father tax revenue is calculated as follows: $[(351,000-335,800)=15,200 \times 0.59]+$ $[(335,800-278,00)=57,800 \times 0.4348]=34,099 \mathrm{DKK}$.

${ }^{38}$ See OECD.Stat for more details: http://stats.oecd.org/Index.aspx?DataSetCode=SOCX_AGG.

${ }^{39}$ In 2008, the Danish age 18-64 population was 3,418,273 according to Statistics Denmark, and approximately 7 percent of them were receiving disability income (Bingley et al., 2011). This amounts to $0.07 * 3,418,273=239,279$ recipients.
} 
at approximately 20 million DKK (\$3 million). ${ }^{40}$

Third, we observe changes in father-child co-residence and both parents' post-separation fertility. The welfare effects of increased fertility are hard to measure, and in part depend on the optimal fertility rate for Denmark. Since the current fertility rate in Denmark is 1.7 and lower than the replacement rate, it is possible to make an argument that higher fertility is welfare-improving. ${ }^{41}$ However, the fact that the increase in fertility is happening among parents who already have children with prior partners makes welfare implications more complicated since per-child resources likely decline in these families. Similarly, it is difficult to assess whether the decline in father-child co-residence is beneficial or hurtful to families.

In sum, a complete welfare analysis of child support obligations is nearly impossible. Nevertheless, the discussion here suggests that any welfare calculation must account for parental behavioral responses in addition to the direct costs and benefits associated with the transfer of income from non-custodial fathers to single-mother households.

Finally, since one of the primary goals of child support policies is to improve the well-being of children, we have also attempted to analyze child outcomes as an alternative way of studying welfare. We have examined effects on children's outpatient visits to general hospitals, emergency room (ER) visits, and hospitalizations at general hospitals. Our analyses yield mostly small and insignificant coefficients. ${ }^{42}$ However, these are rather extreme measures of child welfare, and they do not shed light on important outcomes such as measures of children's psychological well-being.

\section{Conclusion}

As growing numbers of children in developed countries have parents who are divorced or separated, understanding the causal impacts of government interventions targeting their families is important. Since unmarried and divorced mothers have historically retained physical custody of their children and had full parental rights, most of these government interventions are centered around encouraging father involvement. These policies share the underlying assumption that father involvement is essential to child well-being and seek to reduce public spending by shifting the burden of support of single-mother households from government programs to the children's fathers.

However, the implications of such policies for both child well-being and public budgets depend

\footnotetext{
${ }^{40}$ This value is calculated as follows: We estimate a 0.0012 increase in the likelihood of disability insurance takeup, which translates to $0.0012 * 240,000=288$ additional recipients. This means that costs are increased by $292 *$ $69,000 \mathrm{DKK}=19,872,000 \mathrm{DKK}$.

${ }^{41}$ See: http://kff.org/global-indicator/total-fertility-rate/ for data on fertility rates.

${ }^{42}$ These results are available on request.
} 
crucially on their causal impacts on parental behavior. This type of research has thus far been infeasible on a large scale in the United States primarily due to data constraints, and the Danish context provides a unique opportunity to study these issues. We exploit Danish administrative data together with non-linearities in child support guidelines that assign non-custodial parents different obligations according to their incomes, numbers of children, and separation years to study the causal effects of child support mandates on parental outcomes. We estimate that a 1,000DKK increase in a father's average annual child support obligation is associated with about a 506DKK increase in the average annual child support payment.

We also show parental responses on other margins. In particular, higher obligations reduce the likelihood that fathers live with their children in at least one year post-separation, providing some evidence of substitution between monetary and non-pecuniary paternal investments. Additionally, we find that child support obligations increase post-separation fertility for both parents. Both parents are more likely to have additional children while married to or cohabiting with new partners; mothers are also more likely to have children outside these unions. The fertility effect for mothers is consistent with a positive income-fertility relationship, while the fertility effect for fathers is consistent with increased demand for new offspring as a result of reduced contact with existing children. Finally, we find evidence that among higher-income fathers for whom child support obligations represent taxes on earnings, higher obligations are associated with reductions in labor force participation and transitions into disability insurance and early retirement programs.

The findings in this paper point to important parental behavioral responses to redistributive policies meant to address the needs of children growing up with divorced or separated parents. By placing mandates on non-custodial parents to make financial transfers to their children, these policies can disincentivize other forms of non-pecuniary involvement. Moreover, these obligations generate shocks to parental income and time allocation, and can thus impact their subsequent family formation decisions and the division of resources across children. As such, the net impacts on child investment levels and overall child well-being are complicated and ambiguous. Our results cannot directly speak to these implications, although future research might shed light on these issues by exploring the effects of child support mandates on a wide range of children's outcomes.

The net effects on public spending are also potentially unclear. As we discuss in Section 6.7, the fact that some fathers respond to higher obligations by exiting the labor force and taking up disability insurance or early retirement benefits reveals a possible increase in public sector costs and a reduction in tax revenues. Of course there may also be some savings for public budgets, such as those due to reductions in maternal take-up of municipal benefits and support programs (e.g., 
reduced-cost childcare and housing subsidies), which we do not observe in our data. Nevertheless, our findings suggest that child support mandates could have unintended consequences for public spending.

\section{References}

Aizer, A. and McLanahan, S. (2006). The impact of child support enforcement on fertility, parental investments, and child well-being. Journal of Human Resources, 41 (1), 28-45.

Almond, D. and Rossin-Slater, M. (2013). Paternity acknowledgment in 2 million birth records from michigan. PloS one, 8 (7), e70042.

Argys, L. M. and Peters, H. E. (2001). Interactions between unmarried fathers and their children: The role of paternity establishment and child-support policies. American Economic Review, 91 (3), 125-129.

Autor, D. and Duggan, M. (2003). The rise in the disability rolls and the decline in unemployment. The Quarterly Journal of Economics, 118 (1), 157-206.

Bedard, K. and Deschenes, O. (2005). Sex preferences, marital dissolution, and the economic status of women. Journal of human Resources, 40 (2), 411-434.

Bingley, P., Gupta, N. D. and Pedersen, P. J. (2011). Disability Programs, Health and Retirement in Denmark since 1960. Working Paper 17138, National Bureau of Economic Research.

Bjarnason, T. and Arnarsson, A. M. (2011). Joint physical custody and communication with parents: a cross-national study of children in 36 western countries. Journal of Comparative Family Studies, pp. 871-890.

Black, D., Daniel, K. and Sanders, S. (2002). The impact of economic conditions on participation in disability programs: Evidence from the coal boom and bust. American Economic Review, pp. 27-50.

Bratsberg, B., Fevang, E. and Røed, K. (2010). Disability in the welfare state: An unemployment problem in disguise? Tech. Rep. 4897, Institute for the Study of Labor (IZA).

Brewer, M., Ratcliffe, A. and Smith, S. (2012). Does welfare reform affect fertility? evidence from the uk. Journal of Population Economics, 25 (1), 245-266.

Brown, D., Kowalski, A. E. and Lurie, I. Z. (2014). Medicaid as an Investment in Children: What is the Long-Term Impact on Tax Receipts? Working Paper 20835, National Bureau of Economic Research.

Brown, M. and Flinn, C. J. (2011). Family law effects on divorce, fertility and child investment, New York University, unpublished manuscript.

Cancian, M., Heinrich, C. and Chung, Y. (2013). Discouraging disadvantaged fathers' employment: An unintended consequence of policies designed to support families. Journal of Policy Analysis and Management, 32 (4), 758-784.

- Meyer, D. and Roff, J. (2007). Testing New Ways to Increase the Economic Well-Being of Single-Parent Families: The Effects of Child Support Policies on Welfare Participants. Discussion Paper 1330-07, Institute for Research on Poverty.

- and Meyer, D. R. (2014). Testing the economic independence hypothesis: The effect of an exogenous increase in child support on subsequent marriage and cohabitation. Demography, $\mathbf{5 1}$ (3), $857-880$. 
- - - and HAN, E. (2011). Child support: responsible fatherhood and the quid pro quo. The ANNALS of the American Academy of Political and Social Science, 635 (1), 140-162.

Case, A. (1998). The effects of stronger child support enforcement on nonmarital fertility. In I. Garfinkel, S. McLanahan, D. Meyer and J. Seltzer (eds.), Fathers under fire: The revolution in child support enforcement, New York: Russell Sage Foundation, pp. 191-215.

Chetty, R., Friedman, J. N. and Rockoff, J. (2011). New evidence on the long-term impacts of tax credits, Unpublished manuscript, Harvard University.

Cuesta, L. and Cancian, M. (2015). The effect of child support on the labor supply of custodial mothers participating in tanf. Children and Youth Services Review, 54, 49-56.

Currie, J. and Gruber, J. (1996). Saving babies: The efficacy and cost of recent changes in the medicaid eligibility of pregnant women. Journal of Political Economy, 106 (6), 1263-1296.

Dahl, G. B. and Lochner, L. (2012). The impact of family income on child achievement: Evidence from the earned income tax credit. American Economic Review, 102 (5), 1927-1956.

— and Moretti, E. (2008). The demand for sons. The Review of Economic Studies, 75 (4), $1085-1120$.

Del Boca, D. (2003). Mothers, fathers, and children after divorce: The role of institutions. Journal of Population Economics, 16, 399-422.

— and Flinn, C. J. (1995). Rationalizing child-support decisions. The American Economic Review, pp. 1241-1262.

- and Ribero, R. (2003). Visitations and transfers after divorce. Review of the Economics of the Household, 1, 187-204.

Feenberg, D. (1987). Are tax price models really identified: The case of charitable giving. National Tax Journal, pp. 629-633.

Flinn, C. J. (2000). Modes of interaction between divorced parents. International Economic Review, 41 (3), 545-578.

Freeman, R. B. and Waldfogel, J. (1998). Does child support enforcement policy affect male labor supply. In I. Garfinkel, S. McLanahan, D. Meyer and J. Seltzer (eds.), Fathers Under Fire: The Revolution in Child Support Enforcement, New York: Russell Sage Foundation, pp. 94-127.

- and - (2001). Dunning delinquent dads: The effects of child support enforcement policy on child support receipt by never married women. Journal of Human Resources, 36 (2), 207-225.

Garfinkel, I., Mclanahan, S., Meyer, D. and Seltzer, J. (1998). Fathers under fire: The revolution in child support enforcement. Russell Sage Foundation Publications.

Gruber, J. (2000). Disability insurance benefits and labor supply. The Journal of Political Economy, 108 (6), 1162-1183.

- and SaEz, E. (2002). The elasticity of taxable income: evidence and implications. Journal of public Economics, 84 (1), 1-32.

— and Wise, D. A. (2004). Social Security Programs and Retirement around the World: MicroEstimation. University of Chicago press.

- and - (2009). Social security programs and retirement around the world: Fiscal implications of reform. University of Chicago press.

Gunter, S. P. (2013). Effects of child support pass-through and disregard policies on in-kind child support. Review of Economics of the Household, 11 (2), 193-209. 
Halla, M. (2013). The effect of joint custody on family outcomes. Journal of the European Economic Association, 11 (2), 278-315.

Holzer, H. J., Offner, P. and Sorensen, E. (2005). Declining employment among young black less-educated men: The role of incarceration and child support. Journal of Policy Analysis and Management, 24 (2), 329-350.

Hoynes, H. W. (1997). Work, welfare, and family structure: What have we learned? In A. Auerbach (ed.), Fiscal Policy: Lessons from Economic Research, MIT Press, pp. 101-146.

HuAnG, C.-C. (2002). The impact of child support enforcement on nonmarital and marital births: Does it differ by racial and age groups? Social Service Review, 76 (2), 275-301.

- and Han, K.-Q. (2012). Child support enforcement in the united states: Has policy made a difference? Children and Youth Services Review, 34 (4), 622-627.

Kampmann, J. and Nielsen, H. W. (2004). Socialized childhood: Children's childhoods in Denmark. In A.-M. Jensen, A. Ben-Arieh, C. Conti, M. N. Ghiolla Phadraig and H. W. Nielsen (eds.), Children's Welfare in Ageing Europe, vol. 2, pp. 649-702.

Kim, Y., Cancian, M. and Meyer, D. R. (2015). Child support and subsequent nonmarital fertility with a new partner. Journal of Family Issues, p. 0192513X14565701.

Laroque, G. and Salanié, B. (2008). Does fertility respond to financial incentives? Discussion Paper 3575, Institute for the Study of Labor (IZA).

Larsen, M. and Pedersen, P. J. (2012). Paid Work after Retirement: Recent Trends in Denmark. Discussion Paper 6537.

Lerman, R. I. and Sorenson, E. (2003). Child support: Interactions between private and public transfers. In Means-tested transfer programs in the United States, University of Chicago Press, pp. 587-628.

Lundberg, S., Mclanahan, S. and Rose, E. (2007). Child gender and father involvement in fragile families. Demography, 44 (1), 79-92.

— and Rose, E. (2003). Child gender and the transition to marriage. Demography, 40 (2), 333-349.

Milligan, K. (2005). Subsidizing the stork: New evidence on tax incentives and fertility. Review of Economics and Statistics, 87 (3), 539-555.

— and Stabile, M. (2011). Do child tax benefits affect the well-being of children? evidence from canadian child benefit expansions. American Economic Journal: Economic Policy, 3 (3), $175-205$.

Moffitt, R. (2002). Welfare programs and labor supply. In A. Auerbach and M. Feldstein (eds.), Handbook of Public Economics, vol. 4, Elsevier, pp. 2393-2430.

Moffitt, R. A. (1998). The effect of welfare on marriage and fertility. In R. A. Moffitt (ed.), Welfare, the Family, and Reproductive Behavior:: Research Perspectives, National Academies Press, p. 50.

NEAL, D. (2004). The relationship between marriage market prospects and never-married motherhood. Journal of Human Resources, 39 (4), 938-957.

Nepomnyaschy, L. (2007). Child support and father-child contact: Testing reciprocal pathways. Demography, 44 (1), 93-112.

- and Garfinkel, I. (2010). Child support enforcement and fathers' contributions to their nonmarital children. The Social service review, 84 (3), 341. 
Peters, H. E., Argys, L. M., Howard, H. W. and Butler, J. (2004). Legislating love: the effect of child support and welfare policies on father-child contact. Review of Economics of the Household, 2 (3), 255-274.

Piketty, T. and Saez, E. (2013). Optimal labor income taxation. In A. J. Auerbach, R. Chetty, M. Feldstein and E. Saez (eds.), Handbook of Public Economics, vol. 5, pp. 391-474.

Pirog, M. A. and Ziol-Guest, K. M. (2006). Child support enforcement: Programs and policies, impacts and questions. Journal of Policy Analysis and Management, 25 (4), 943-990.

Plotnick, R. D., Garfinkel, I., Mclanahan, S. S. and Ku, I. (2004). Better child support enforcement can it reduce teenage premarital childbearing? Journal of Family Issues, 25 (5), $634-657$.

Roff, J. and Lugo-GiL, J. (2012). A model of child support and the underground economy. Labour Economics, 19 (5), 668-681.

Saez, E., Slemrod, J. and Giertz, S. H. (2012). The elasticity of taxable income with respect to marginal tax rates: A critical review. Journal of Economic Literature, 50 (1), 3-50.

Schoeni, R. and Blank, R. (2000). What has welfare reform accomplished? Impacts on welfare participation, employment, income, poverty, and family structure. Working Paper 7627, National Bureau of Economic Research.

Skinner, C., Bradshaw, J. and Davidson, J. (2007). Child Support Policy: An International Perspective. Research report, Department for Work and Pensions.

Slemrod, J. (1985). An empirical test for tax evasion. The Review of Economics and Statistics, pp. $232-238$.

Sorensen, E. and Halpern, A. (1999). Child support enforcement: How well is it doing? Discussion Paper 99-11, The Urban Institute.

- and Olivier, H. (2002). Child support reforms in PRWORA: Initial impacts. Discussion Paper 02-02, The Urban Institute.

Stevenson, B. and Wolfers, J. (2006). Bargaining in the shadow of the law: Divorce laws and family distress. The Quarterly Journal of Economics, 121 (1), 267-288.

TARTARI, M. (2014). Divorce and the cognitive achievement of children, University of Chicago, unpublished manuscript.

Weinberg, D. H. (2006). Income data quality issues in the CPS. Monthly Labor Review, 129, 38.

WeIss, Y. and Willis, R. (1985). Children as collective goods and divorce settlements. Journal of Labor Economics, 3 (3), 268-292.

WiLlis, R. J. (1999). A theory of out-of-wedlock childbearing. Journal of Political Economy, 107 (S6), S33-S64.

Wolfers, J. (2006). Did unilateral divorce laws raise divorce rates? a reconciliation and new results. The American Economic Review, 96 (5), 1802-1820. 
Figure 1: Government-Mandated Child Support Obligations by Separation Year and Average Predicted Obligation by Father Income in Separation Year, Year 2000 DKK

(a) 1 Child Families

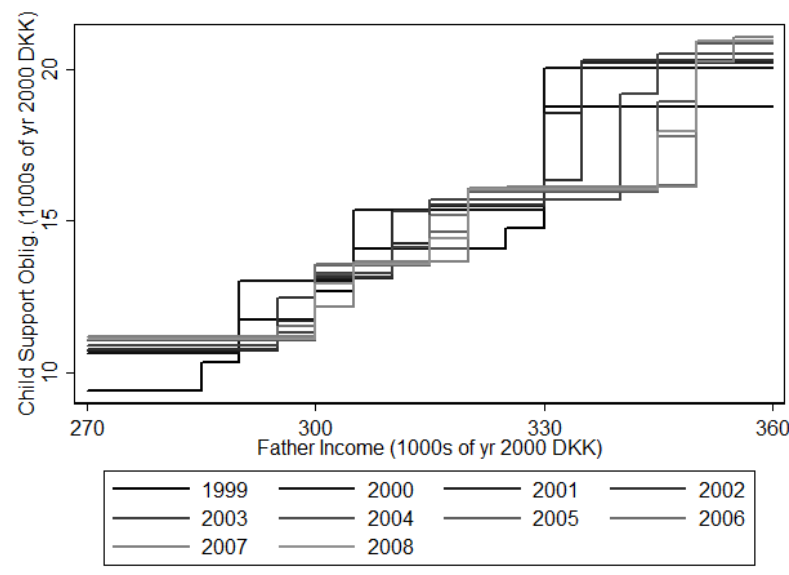

(c) 1 Child Families

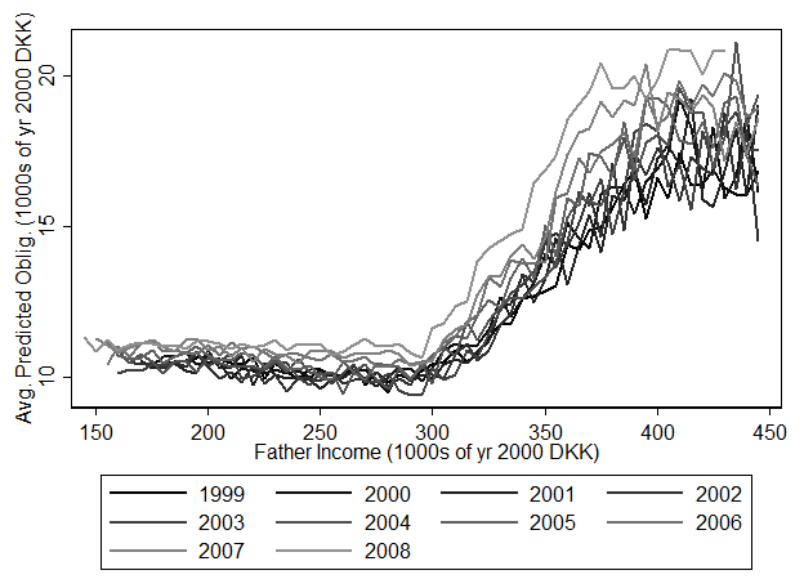

(b) 2 Child Families

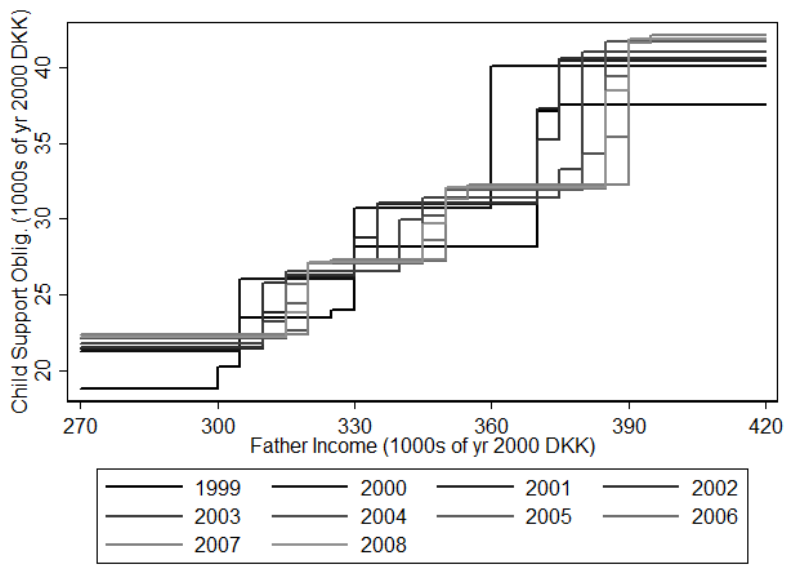

(d) 2 Child Families

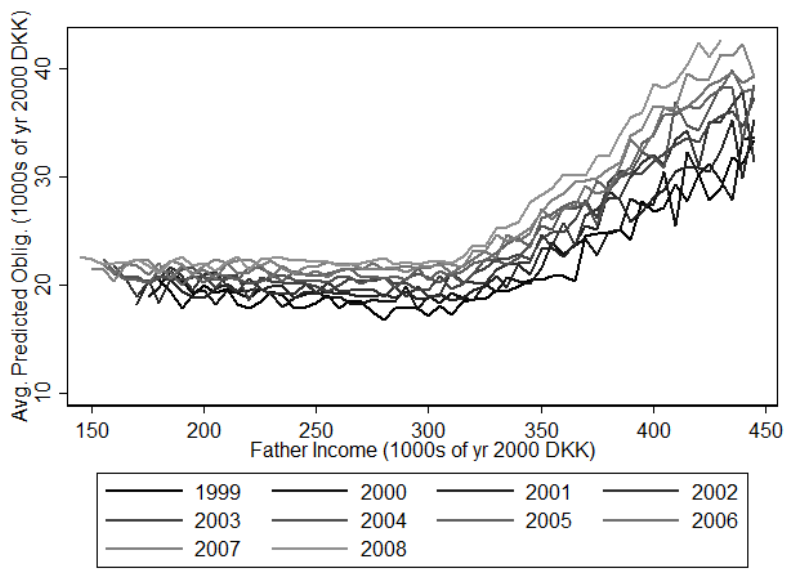

Notes: Sub-figures (a) and (b) show the relationship between a non-custodial father's income and the child support obligation by year for families with one and two children, respectively. Sub-figures (c) and (d) show the relationship between a non-custodial father's income and the average predicted obligation by year of separation for families with one and two children, respectively. Units are 1000s of real year 2000 DKK. 
Figure 2: Variation in the Average Predicted Obligation by 20K Father Income Bin, Separation Year, and Number of Children

(a) 1 Child

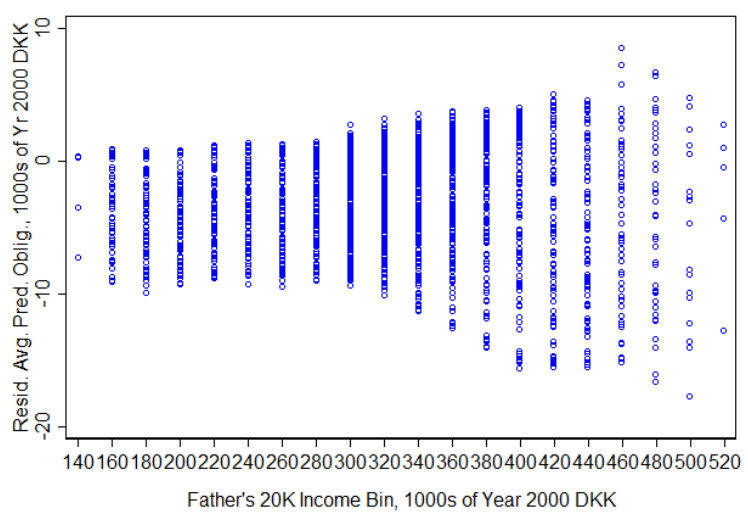

(c) 1 Child

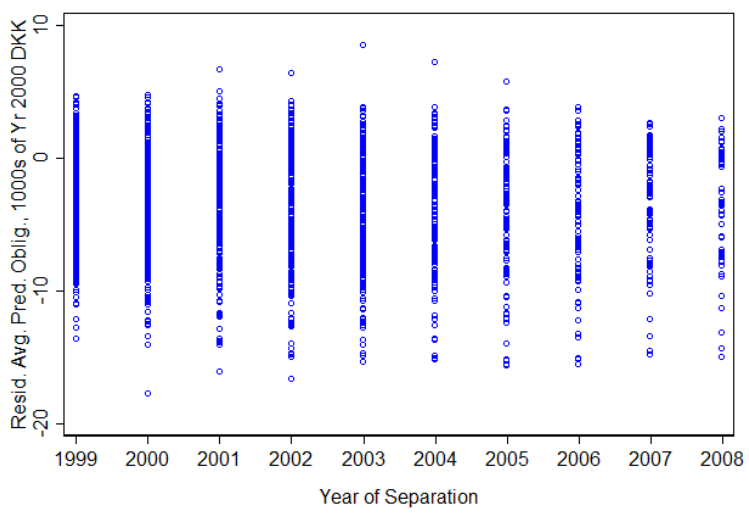

(b) 2 Children

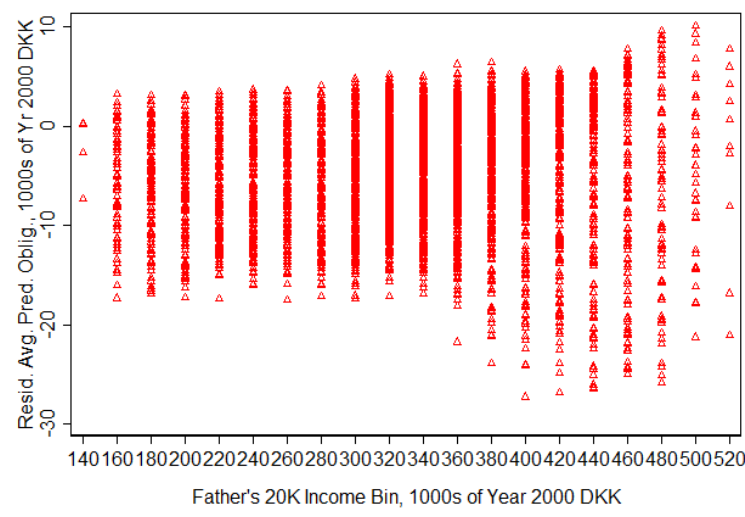

(d) 2 Children

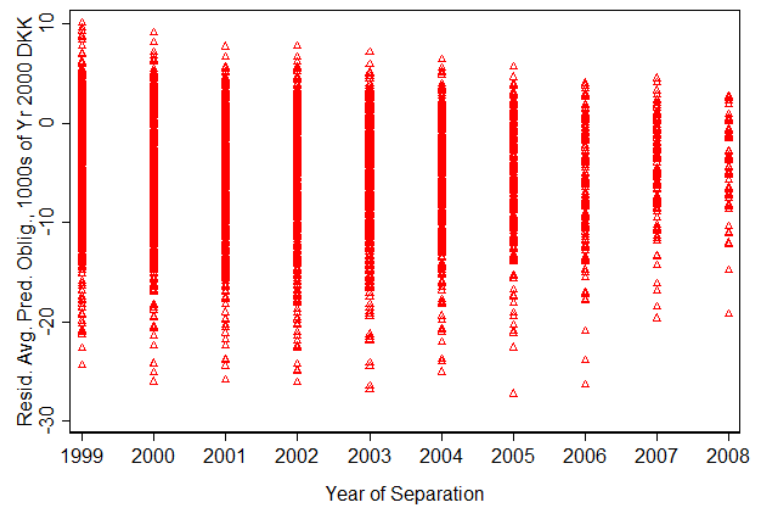

Notes: These figures plot the variation in the residuals of a regression of average predicted obligations on fixed effects for the year of separation, 20,000DKK income bins, and number of children and their double interactions. Sub-figures (a) and (b) show the variation in the average predicted obligation residuals within each 20,000DKK income bin separately by the number of children. Sub-figures (c) and (d) show the variation in the average predicted obligation residuals within each separation year separately by the number of children. Units are 1000s of real year 2000 DKK. 
Figure 3: Effect of Child Support Obligations on Fathers Being Not in the Labor Force (NILF): By Number Years Before and After Separation

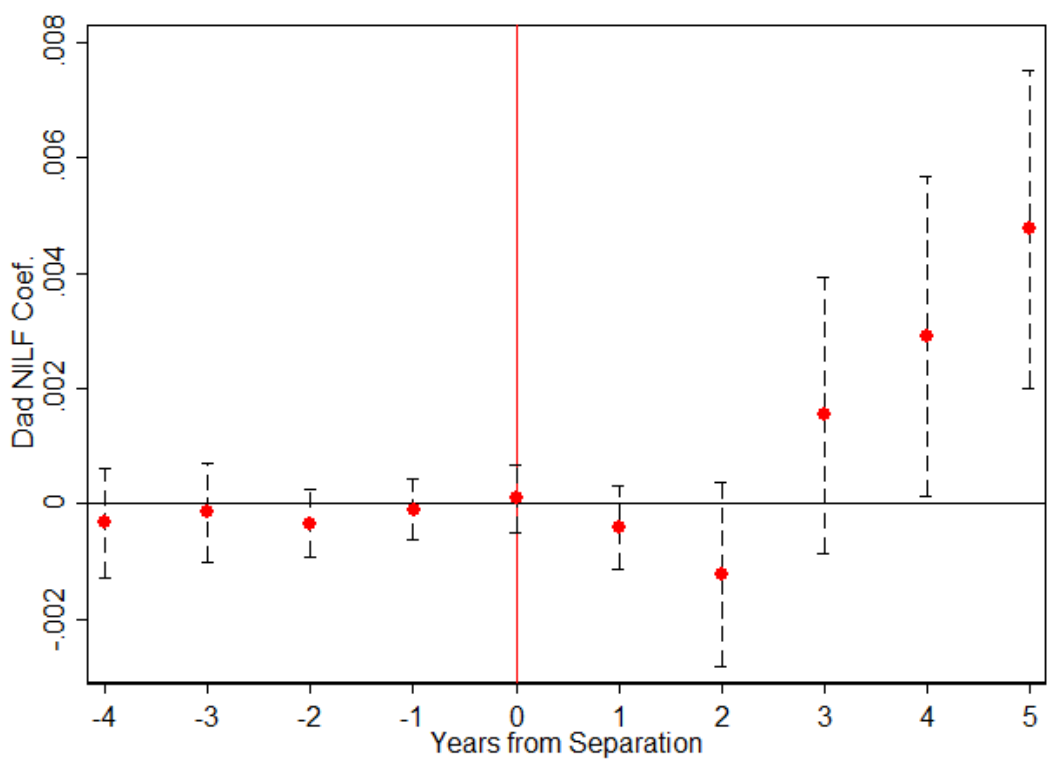

Notes: This figure presents the coefficients and 95\% confidence intervals from 11 separate regressions. For years $x \in[1,5]$, each regression has an indicator for the father being not in the labor force (NILF) in year $x+1$ postseparation as the dependent variable and the average annual obligation over the preceding post-separation years $(0$ to $x$ ) as the explanatory variable (instrumented by the average predicted obligation which is calculated using separationyear income and separation-year number of children). For years $x \in[-5,0]$, each regression has an indicator for the father being not in the labor force (NILF) in year $x$ pre-separation as the dependent variable and the obligation in the year of separation as the explanatory variable. See notes under Table 2 for more information on the sample. 
Table 1: Effect of Child Support Obligations on the Likelihood of Parental Separation

\begin{tabular}{lccccc}
\hline & \multicolumn{4}{c}{ Dep. Var.: } & Parents Separated or Had Out-of-Wedlock/Cohabitation Birth \\
\cline { 2 - 6 } & Poly 1 & Poly 2 & Poly 3 & Poly 4 & $(5)$ \\
& $0.000263^{* * *}$ & $0.000176^{* * *}$ & $-0.000125^{* *}$ & -0.0000791 & 20K Bins \\
\hline Child support & {$[0.0000332]$} & {$[0.0000414]$} & {$[0.0000544]$} & {$[0.0000650]$} & -0.000409 \\
obligation & 0.0316 & 0.0316 & 0.0316 & 0.0316 & $0.000329]$ \\
\hline Mean, dept. var. & 2286550 & 2286550 & 2286550 & 2286550 & 0.0235 \\
$\begin{array}{l}\text { Obs. (father-years) } \\
\text { Number cells }\end{array}$ & & & & & 2286550 \\
\hline
\end{tabular}

Notes: In columns 1-4, units of analysis are father-year observations. In column 5, the units of analysis are cells according to the interactions of 20,000 DKK father income bins, year, and number of children. The regression in column 5 is weighted by the number of father-year observations in each cell. The sample is a panel of fathers of children born in 1985-2010, who appear in the register data in every year over 1998-2010, and who were either married to, cohabiting with, or never-married/non-cohabiting with their oldest child's mother at the time of childbirth for children born in 1998 or later or in 1998 for children born before. Only father-year observations until the year of separation (if it occurs) are kept. The sample is further limited to father-year observations with nominal incomes between 175,000 and 505,000 DKK. (100,000 DKK surrounding the range of the first three cutoffs), and who have either one or two children aged less than 18. In columns 1-4 (column 5), the outcome of interest is an indicator for (fraction of) the parents either separating, divorcing, or have an out-of-wedlock/cohabitation child. All income variables are in year 2000 real units of 1,000 DKK. In columns 1-4, standard errors are robust to heteroskedasticity; in column 5, robust standard errors are clustered on the cell level.

Significance levels: * $\mathrm{p}<0.1 * * \mathrm{p}<0.05 * * * \mathrm{p}<0.01$ 


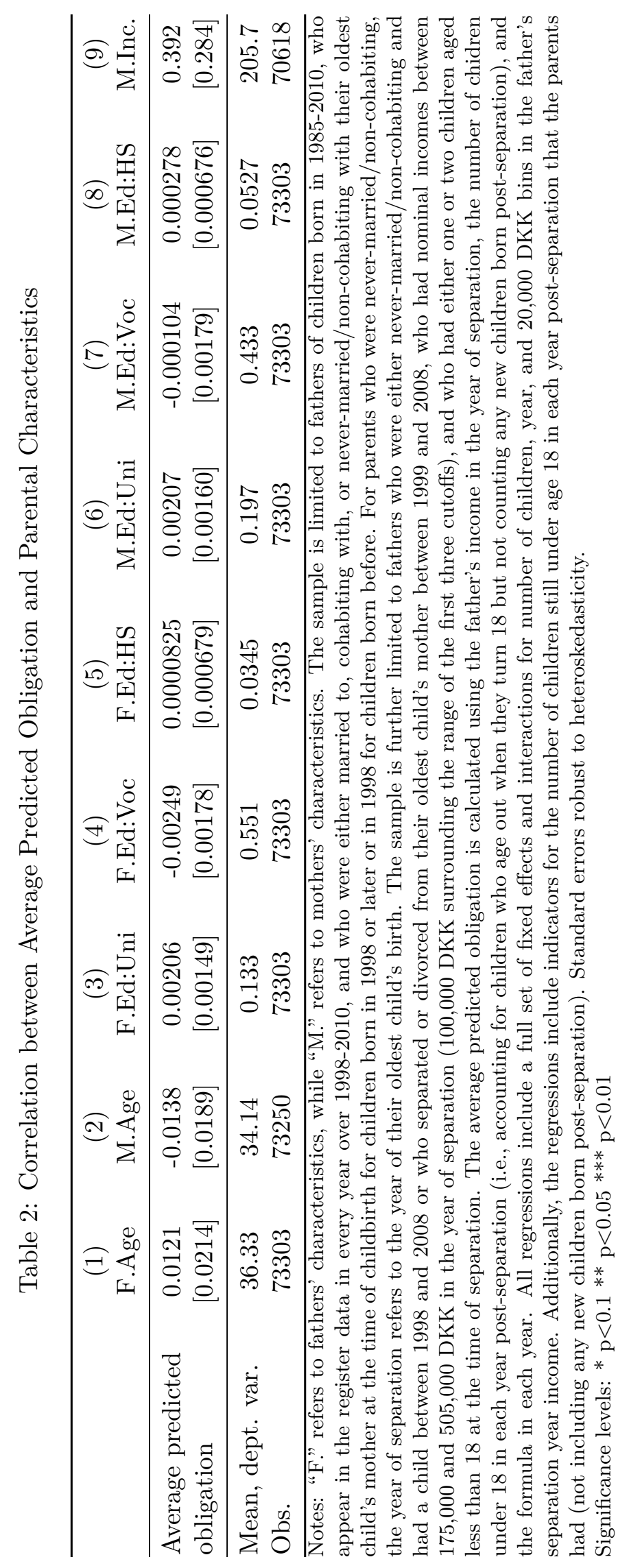


Table 3: IV Effects of Average Child Support Obligations on Fathers' Child Support Payments and Father-Child Co-Residence

(3)

(4)

Avg CS Paid Pay More Than Oblig. Ever Pay Zero Ever Live w/ Child

\begin{tabular}{lcccc}
\hline $\begin{array}{l}\text { Average child } \\
\text { support obligation }\end{array}$ & $0.506^{* * *}$ & $-0.00258^{*}$ & $-0.0132^{* * *}$ & $-0.00567^{* * *}$ \\
{$[0.0365]$} & {$[0.00150]$} & {$[0.00145]$} & {$[0.00200]$} \\
\hline Mean, dept. var. & 9.263 & 0.0756 & 0.737 & 0.278 \\
Fst. Stage Coef. & 0.851 & 0.851 & 0.851 & 0.851 \\
Fst. Stage F-Stat & 2291.7 & 2291.7 & 2291.7 & 2291.7 \\
Obs. & 70468 & 70468 & 70468 & 70468 \\
\hline
\end{tabular}

Notes: The outcomes are defined as follows: 1) "Avg CS Paid" refers to the average annual child support paid by the father in the years post-separation; 2) "Pay More Than Oblig." refers to an indicator for the father's average child support payment being greater than his average child support obligation post-separation; 3) "Ever Pay Zero" refers to an indicator for zero child support paid by the father in at least one year post-separation; 4) "Ever Live w/ Child" refers to an indicator for the father living with the child at least one year post-separation. All income variables are in year 2000 real units of 1,000 DKK. See notes under Table 2 for more information on the sample. All regressions include fixed effects for 20,000 DKK bins in the father's separation year income, number of children at separation, year of separation, and their double interactions. All regressions include controls (measured in the year of separation) for the father's age and age squared, dummies for the father's education (less than high school, high school, vocational/short-term higher ed, college/university, and missing), an indicator for the father being from Western Europe, mother's age and age squared, dummies for the mother's education (less than high school, high school, vocational/short-term higher ed, college/university, and missing), an indicator for the mother being from Western Europe, mother's total income in year 2000 DKK, oldest child's age and age squared, youngest child's age and age squared, an indicator for the oldest child being male, an indicator for the youngest child being male, and indicators for original parental relationship status (married, cohabiting, never-married/non-cohabiting). Additionally, the regressions include indicators for the number of children still under age 18 in each year post-separation that the parents had (not including any new children born post-separation). Standard errors robust to heteroskedasticity.

Significance levels: ${ }^{*} \mathrm{p}<0.1 * * \mathrm{p}<0.05 * * * \mathrm{p}<0.01$ 
Table 4: IV Effects of Average Child Support Obligations on Mothers' Post-Separation Fertility

\begin{tabular}{lcccc}
\hline & \multicolumn{4}{c}{ Mother Has More Kids After Sep. } \\
\cline { 2 - 5 } & $\begin{array}{c}(1) \\
\text { Overall }\end{array}$ & $\begin{array}{c}(2) \\
\text { Mar. }\end{array}$ & $\begin{array}{c}(3) \\
\text { Coh. }\end{array}$ & Not Mar./Coh. \\
\hline Average child & $0.00603^{* * *}$ & $0.00380^{* * *}$ & $0.00149^{* *}$ & $0.000809^{* *}$ \\
support obligation & {$[0.000990]$} & {$[0.000698]$} & {$[0.000732]$} & {$[0.000369]$} \\
\hline Mean, dept. var. & 0.185 & 0.0658 & 0.0922 & 0.0287 \\
Fst. Stage Coef. & 0.852 & 0.852 & 0.852 & 0.852 \\
Fst. Stage F-Stat & 2280.6 & 2280.6 & 2280.6 & 2280.6 \\
Obs. & 68772 & 68772 & 68772 & 68772 \\
\hline
\end{tabular}

Notes: The outcomes are defined as follows: 1) "Overall" refers to an indicator for the mother having any children post-separation (regardless of relationship status); 2) "Mar." refers to an indicator for the mother having more children post-separation while married to a new partner; 3) "Coh." refers to an indicator for the mother having more children post-separation while cohabiting with a new partner; 4) "Not Mar./Coh." refers to an indicator for the mother having more children post-separation while neither married or cohabiting. All income variables are in year 2000 real units of 1,000 DKK. See notes under Tables 2 and 3 for more information on the sample, specifications, and controls. Standard errors robust to heteroskedasticity.

Significance levels: * $\mathrm{p}<0.1 * * \mathrm{p}<0.05 * * * \mathrm{p}<0.01$

Table 5: IV Effects of Average Child Support Obligations on Fathers' Post-Separation Fertility

\begin{tabular}{|c|c|c|c|c|c|}
\hline & \multicolumn{5}{|c|}{ Father Has More Kids After Sep. } \\
\hline & $(1)$ & $(2)$ & $(3)$ & $(4)$ & $(5)$ \\
\hline & Overall & Mar. & Coh. & Not Mar./Coh. & Not living w/ older child \\
\hline Average child & $0.00680^{* * *}$ & $0.00323^{* * *}$ & $0.00324^{* * *}$ & 0.000241 & $0.00741^{* * *}$ \\
\hline support obligation & {$[0.00113]$} & {$[0.000861]$} & {$[0.000815]$} & {$[0.000450]$} & {$[0.00101]$} \\
\hline Mean, dept. var. & 0.186 & 0.0805 & 0.0830 & 0.0238 & 0.148 \\
\hline Fst. Stage Coef. & 0.851 & 0.851 & 0.851 & 0.851 & 0.851 \\
\hline Fst. Stage F-Stat & 2291.7 & 2291.7 & 2291.7 & 2291.7 & 2291.7 \\
\hline Obs. & 70468 & 70468 & 70468 & 70468 & 70468 \\
\hline
\end{tabular}

Notes: The outcomes are defined as follows: 1) "Overall" refers to an indicator for the father having any children post-separation (regardless of relationship status); 2) "Mar." refers to an indicator for the father having more children post-separation while married to a new partner; 3) "Coh." refers to an indicator for the father having more children post-separation while cohabiting with a new partner; 4) "Not Mar./Coh." refers to an indicator for the father having more children post-separation while neither married or cohabiting; 5) "Not living w/ older child" refers to an indicator for the father having more children post-separation while not living with his oldest child. All income variables are in year 2000 real units of 1,000 DKK. See notes under Tables 2 and 3 for more information on the sample, specifications, and controls. Standard errors robust to heteroskedasticity.

Significance levels: * $\mathrm{p}<0.1 * * \mathrm{p}<0.05 * * * \mathrm{p}<0.01$ 


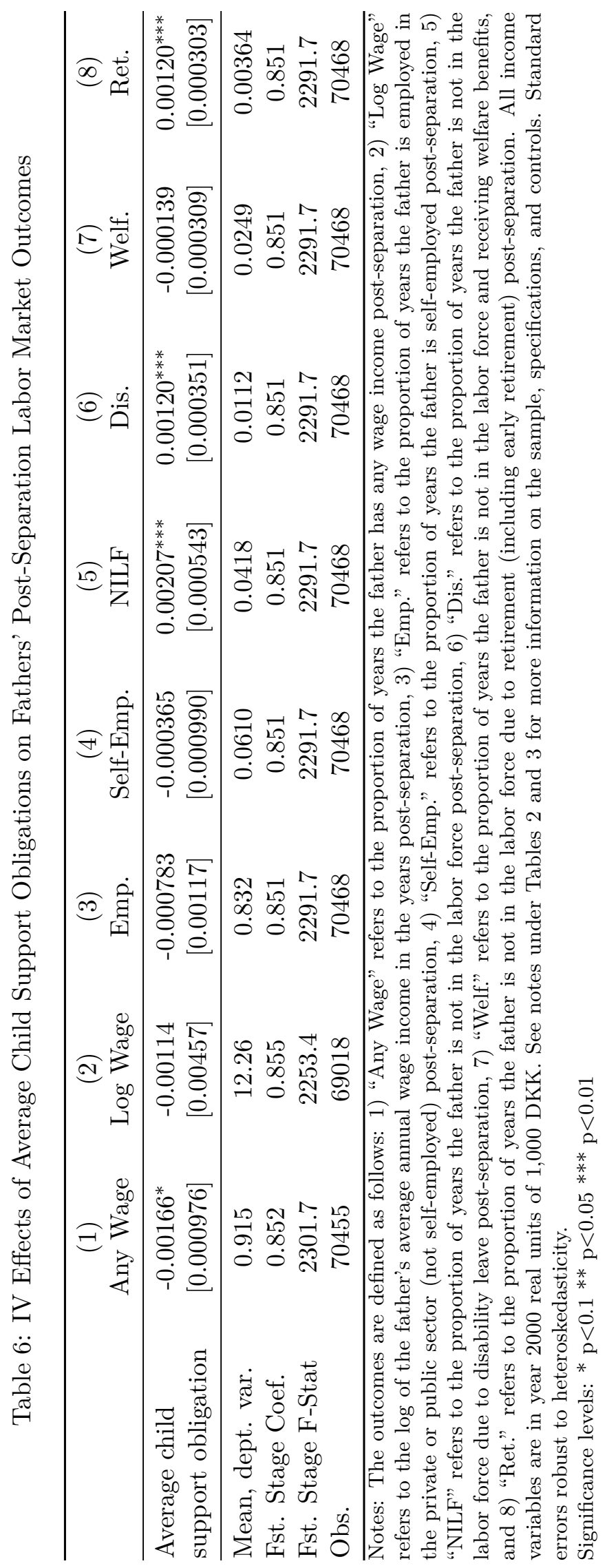




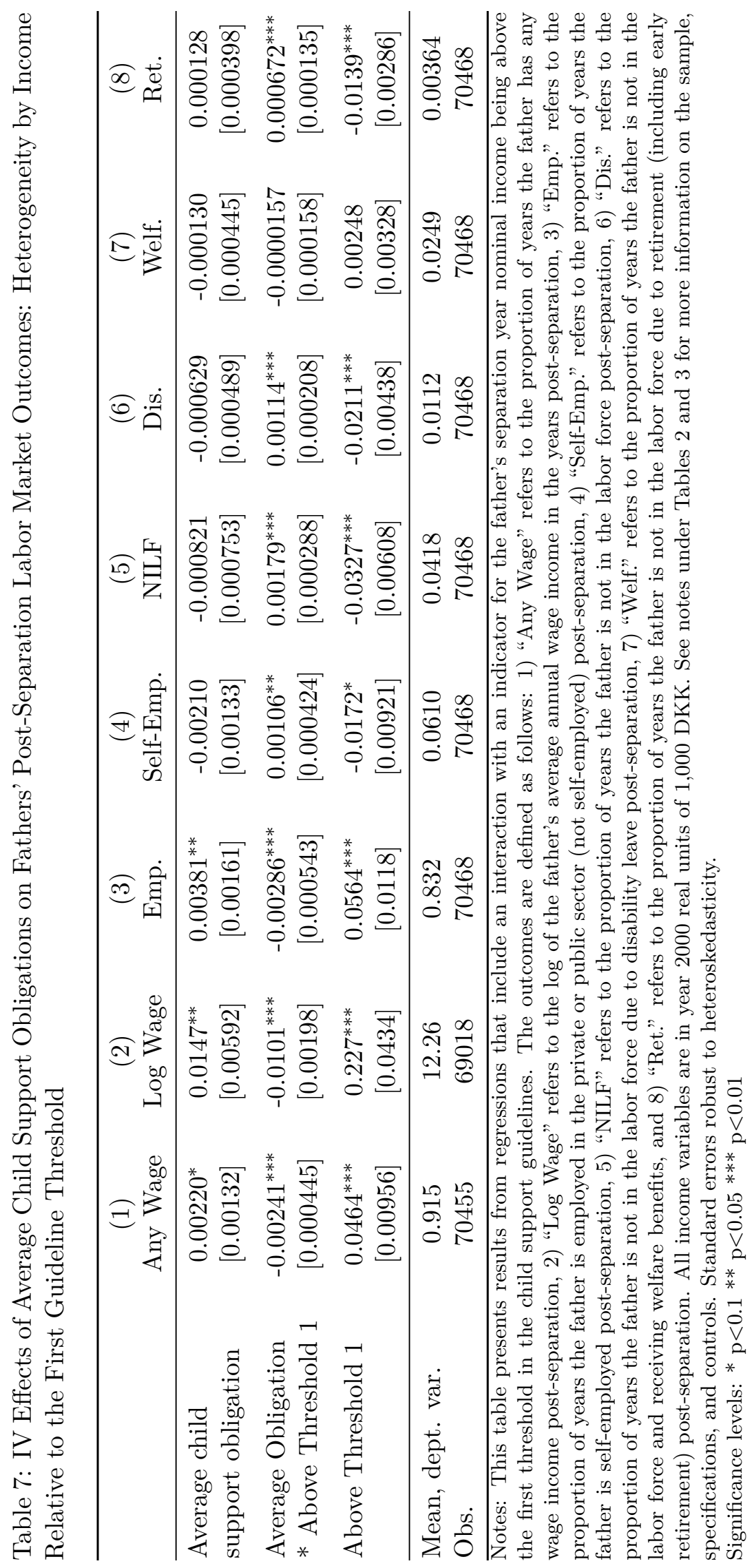




\section{A Appendix Figures and Tables}

Figure A1: Growth Rate of the "Normal Amount" Compared with the Growth Rate of Average Nominal Income Among Fathers

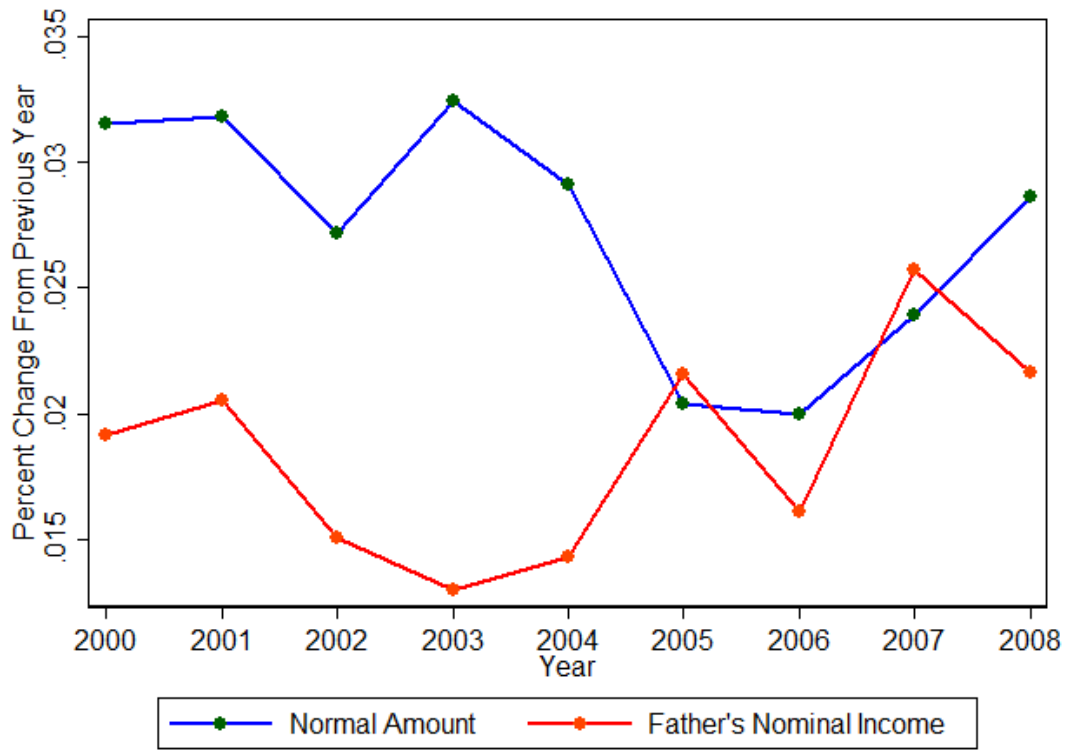

Notes: This figure shows the growth rate in the nominal "normal amount" of the child support obligation (in blue) compared with the growth rate in the average nominal income among fathers in our sample (in red). 
Figure A2: Government-Mandated Child Support Obligations by Year and Father's Income Percentiles, Year 2000 DKK

(a) 1 Child Families

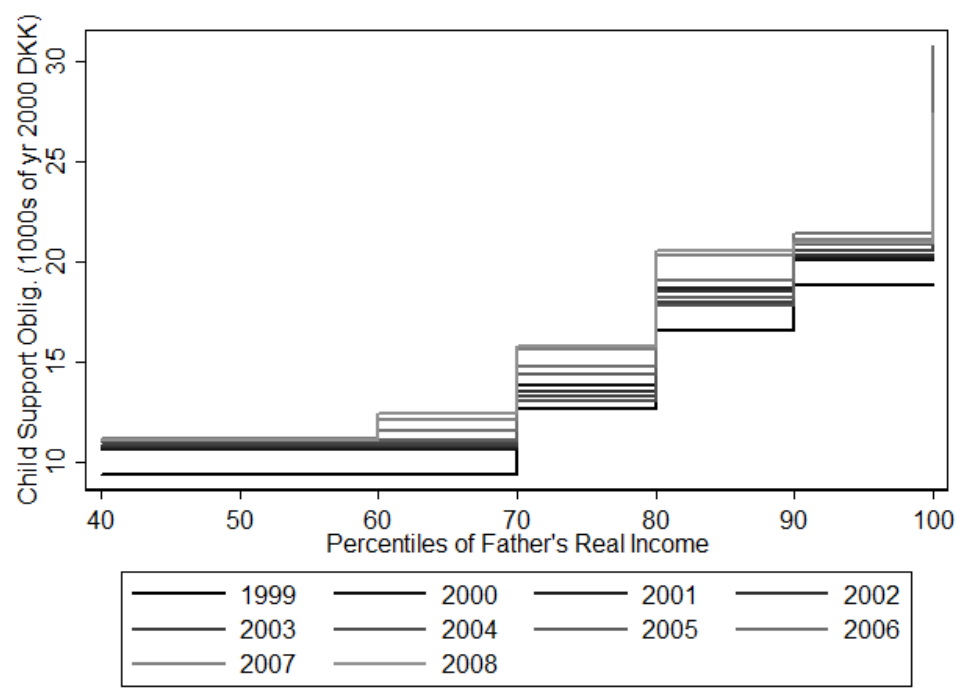

(b) 2 Child Families

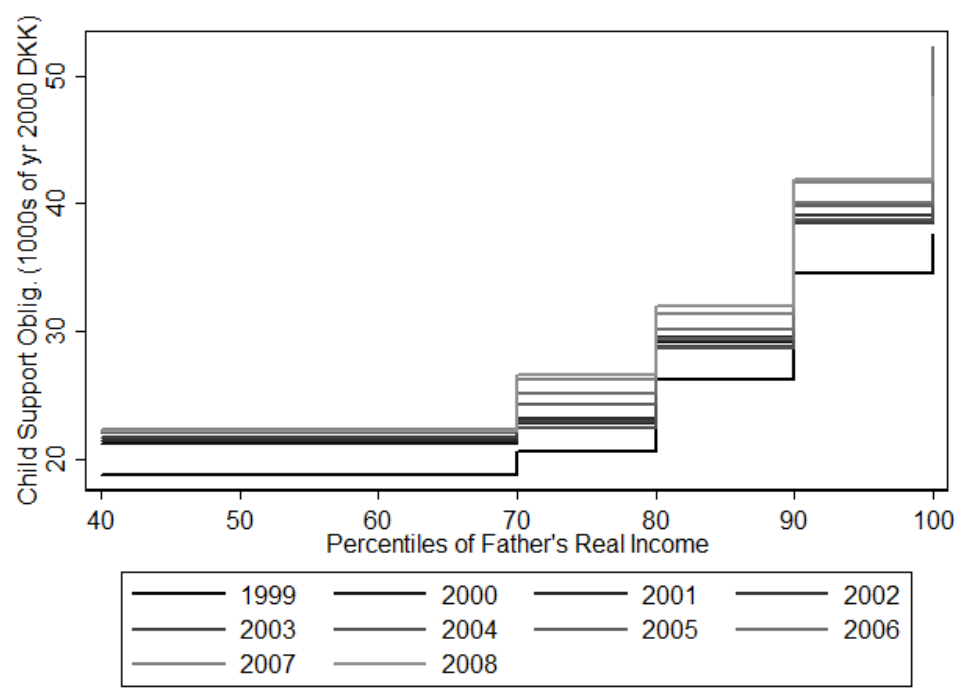

Notes: This figure shows the relationship between a non-custodial father's income percentile and the child support obligation by year for families with one and two children (a and b, respectively). Units are 1000s of real year 2000 DKK. 
Figure A3: First Stage Coefficients by Year, 20K Income Bin, and Number of Children

(a) By Year of Separation

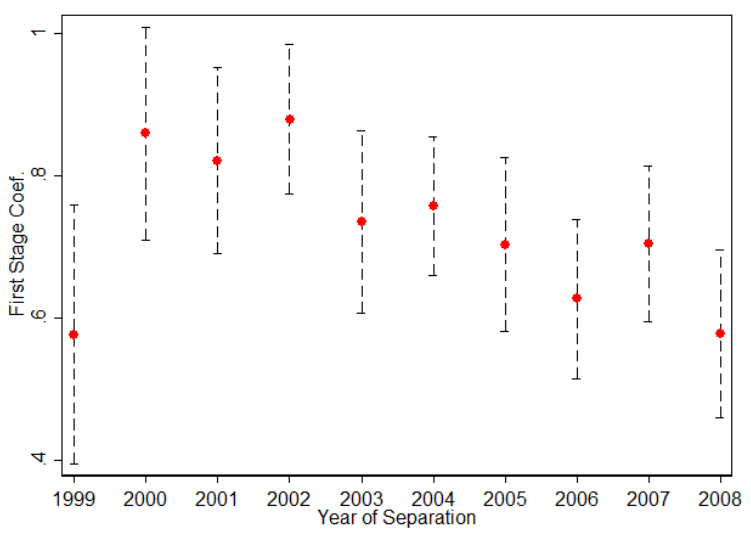

(b) By 20K Income Bin

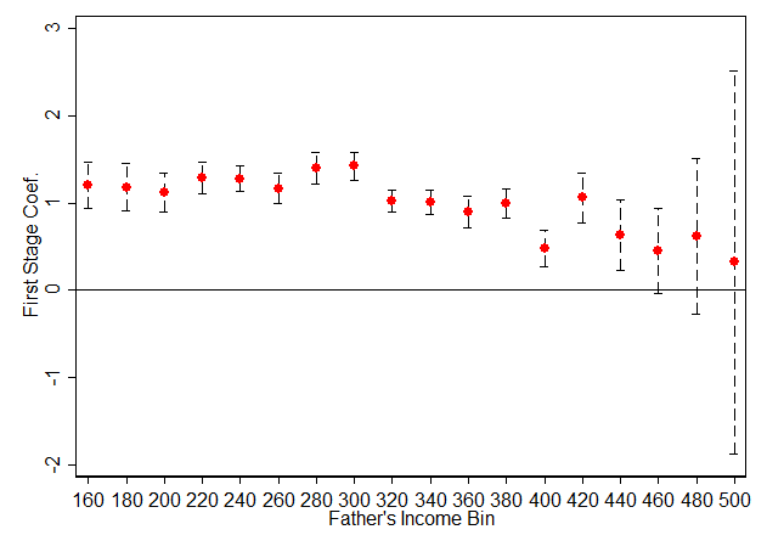

(c) By Number of Children

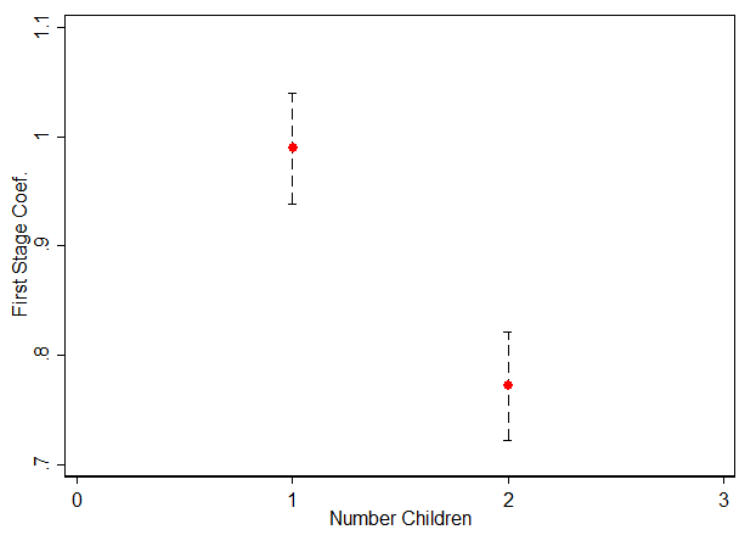

Notes: These figures show the first stage coefficients and $95 \%$ confidence intervals from separate regressions by year of separation (sub-figure a), 20K DKK income bin (sub-figure b), and number of children (sub-figure c). Units are 1000s of real year 2000 DKK. 
Figure A4: The Effects of Child Support Obligations on Father-Child Co-Residence: By Number Years After Separation

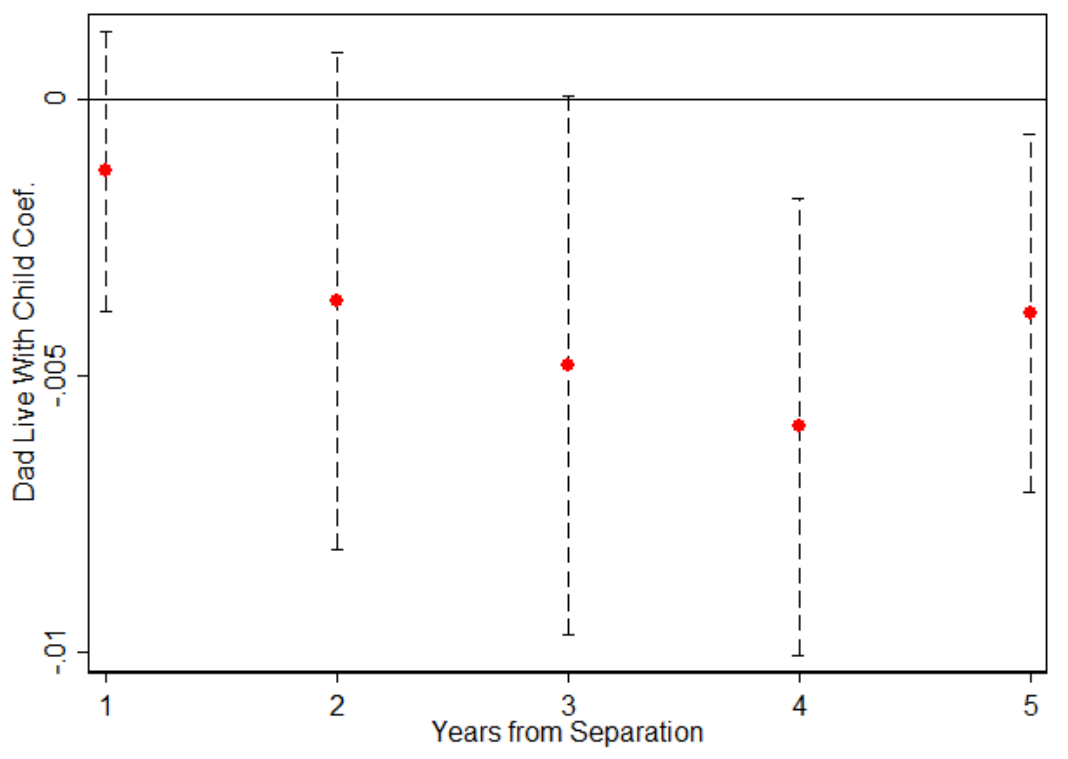

Notes: This figure presents the coefficients and $95 \%$ confidence intervals from five separate regressions. For years $x \in[1,5]$, each regression has an indicator for the father living with his oldest child in year $x+1$ post-separation as the dependent variable and the average annual obligation over the preceding post-separation years ( 0 to $x)$ as the explanatory variable (instrumented by the average predicted obligation which is calculated using separation-year income and separation-year number of children). See notes under Table 2 for more information on the sample. All regressions include fixed effects for 20,000 DKK bins in the father's separation year income, number of children at separation, year of separation, and their double interactions. All regressions include controls (measured in the year of separation) for the father's age and age squared, dummies for the father's education (less than high school, high school, vocational/short-term higher ed, college/university, and missing), an indicator for the father being from Western Europe, mother's age and age squared, dummies for the mother's education (less than high school, high school, vocational/short-term higher ed, college/university, and missing), an indicator for the mother being from Western Europe, mother's total income in year 2000 DKK, oldest child's age and age squared, youngest child's age and age squared, an indicator for the oldest child being male, an indicator for the youngest child being male, and indicators for original parental relationship status (married, cohabiting, never-married/non-cohabiting). Additionally, the regressions include indicators for the number of children still under age 18 in each year post-separation that the parents had (not including any new children born post-separation). Standard errors robust to heteroskedasticity. 
Figure A5: The Effects of Child Support Obligations on Mothers' Subsequent Fertility: By Number Years After Separation

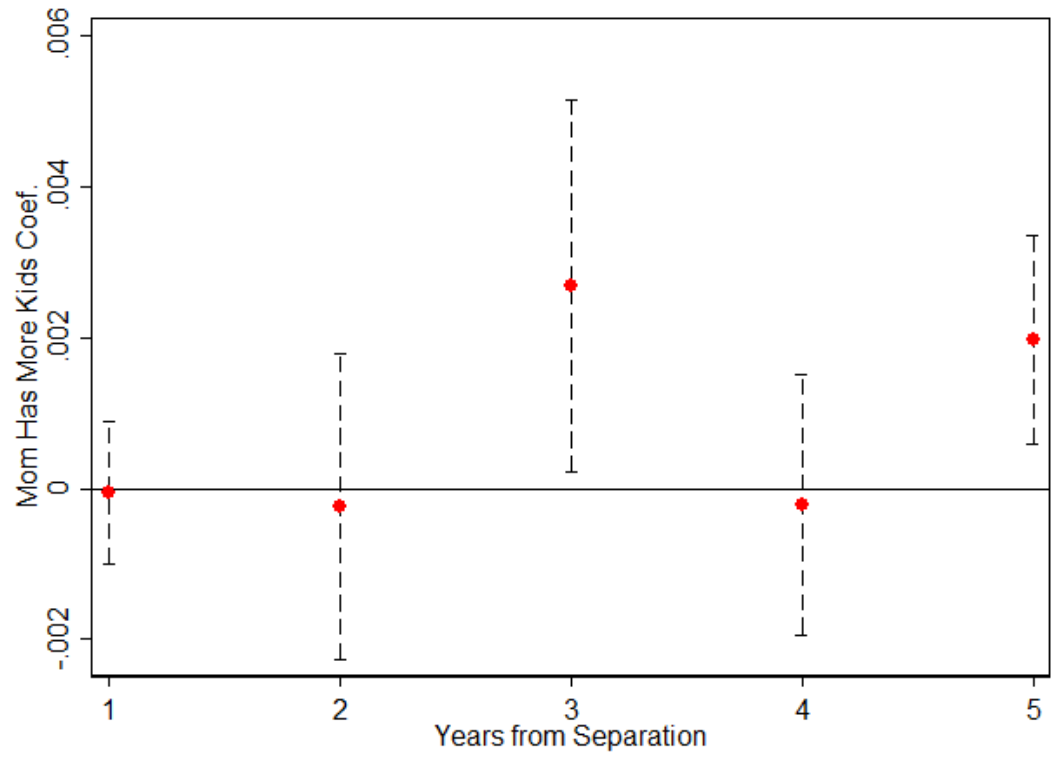

Notes: This figure presents the coefficients and $95 \%$ confidence intervals from five separate regressions. In particular, for years $x \in[1,5]$ - the first five years of separation displayed on the x-axis - each regression has an indicator for the mother having more children in year $x+1$ post-separation as the dependent variable and the average annual obligation over the preceding post-separation years ( 0 to $x$ ) as the explanatory variable (instrumented by the average predicted obligation which is calculated using separation-year income and separation-year number of children). See notes under Table 2 for more information on the sample, and notes under Appendix Figure A4 for more information on the estimation and controls. 
Figure A6: The Effects of Child Support Obligations on Fathers' Subsequent Fertility: By Number Years After Separation

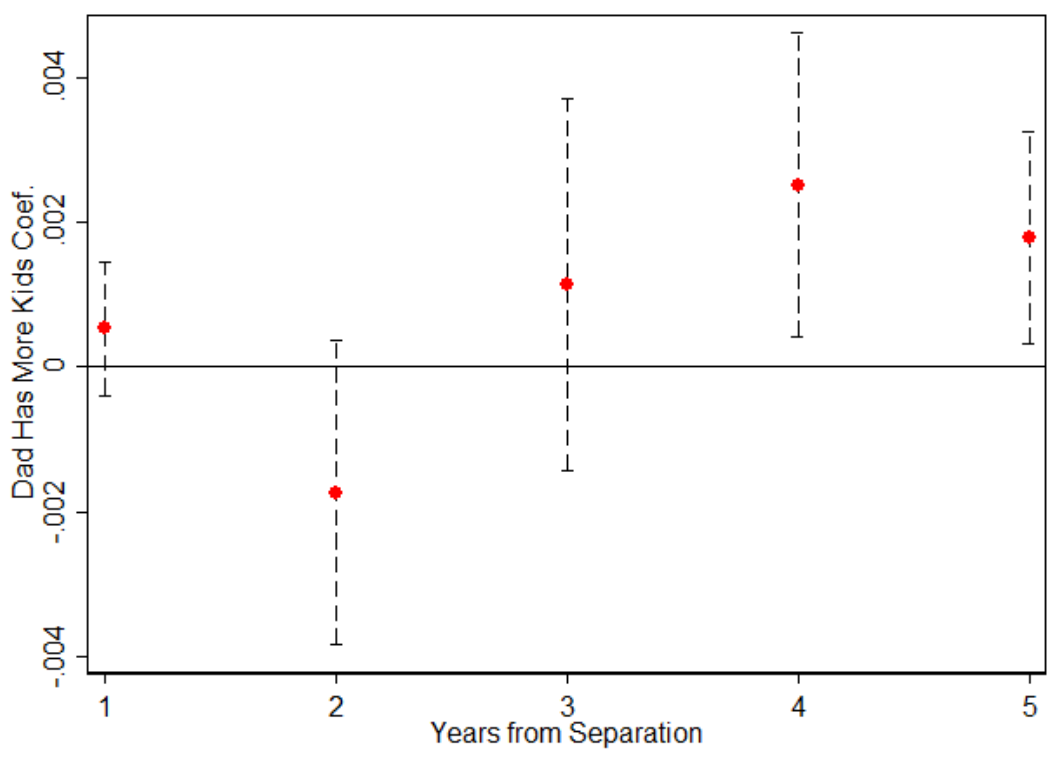

Notes: This figure presents the coefficients and $95 \%$ confidence intervals from five separate regressions. In particular, for years $x \in[1,5]$ - the first five years of separation displayed on the $\mathrm{x}$-axis - each regression has an indicator for the father having more children in year $x+1$ post-separation as the dependent variable and the average annual obligation over the preceding post-separation years ( 0 to $x$ ) as the explanatory variable (instrumented by the average predicted obligation which is calculated using separation-year income and separation-year number of children). See notes under Table 2 for more information on the sample, and notes under Appendix Figure A4 for more information on the estimation and controls. 
Figure A7: IV Coefficients by Year, 50K Income Bin, and Number of Children for Average Child Support Paid as Outcome

(a) By Year of Separation

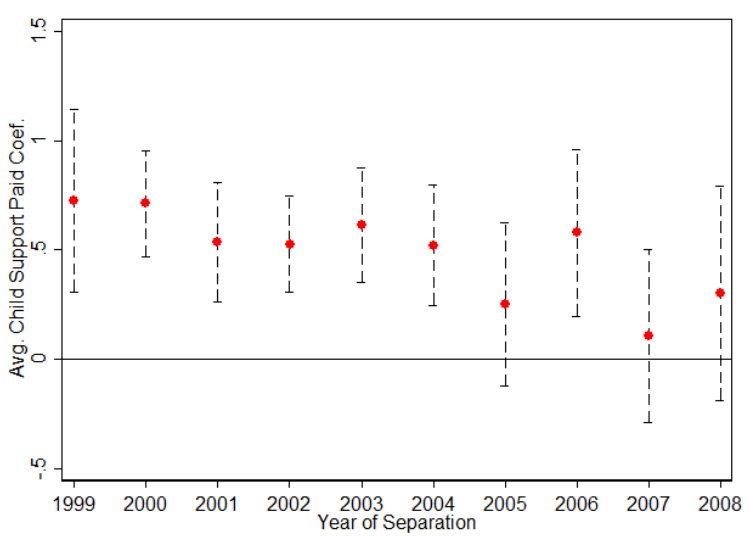

(b) By 50K Income Bin

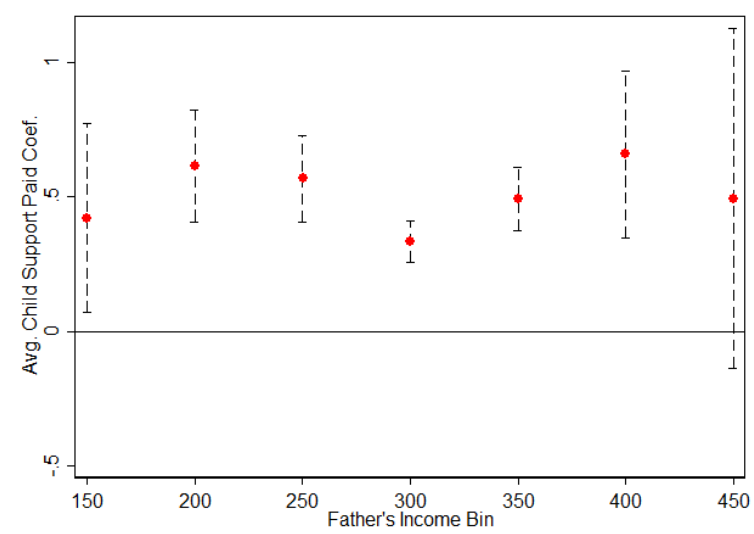

(c) By Number of Children

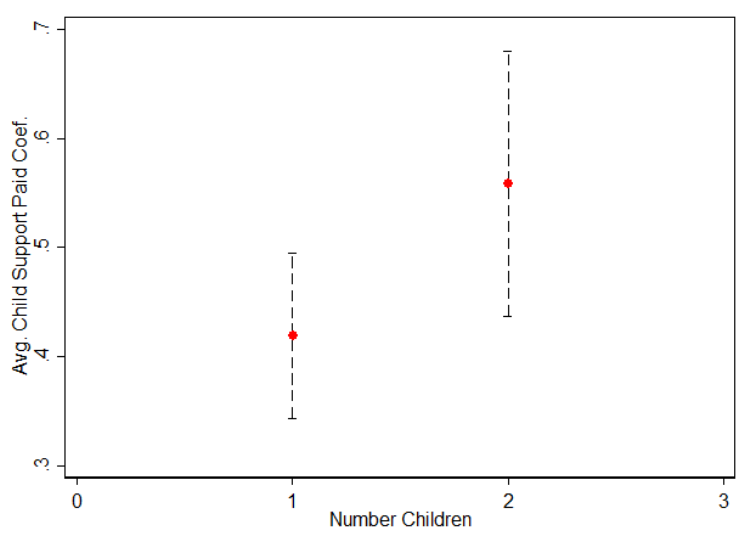

Notes: These figures show the coefficients and $95 \%$ confidence intervals from separate IV regressions by year of separation (sub-figure a), 50K DKK income bin (sub-figure b), and number of children (sub-figure c). The outcome is the average child support paid in the years post-separation. Units are 1000s of real year 2000 DKK. 
Figure A8: IV Coefficients by Year, 50K Income Bin, and Number of Children for Father-Child Co-Residence as Outcome

(a) By Year of Separation

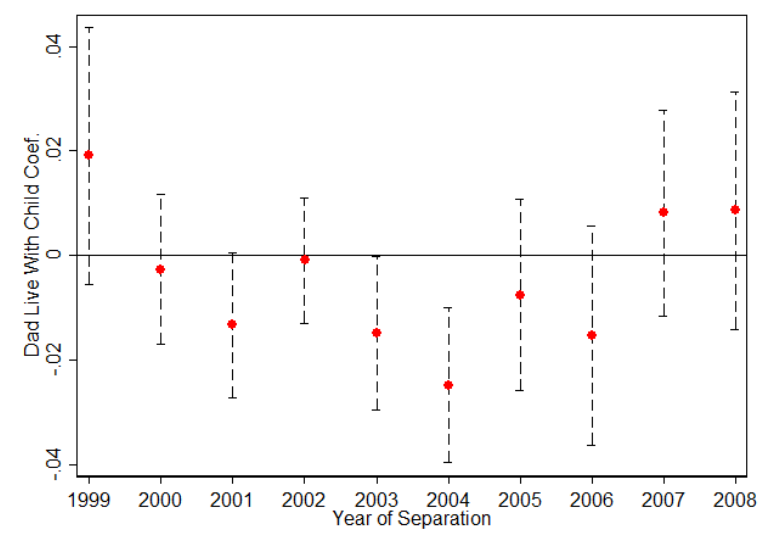

(b) By 50K Income Bin

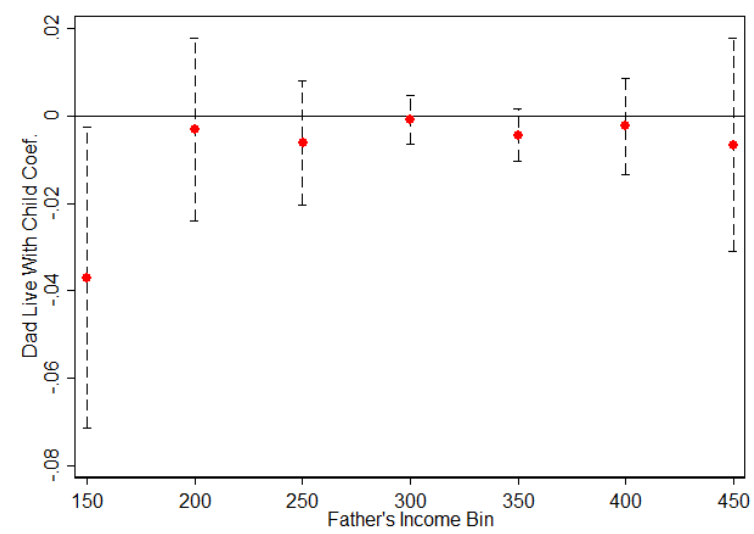

(c) By Number of Children

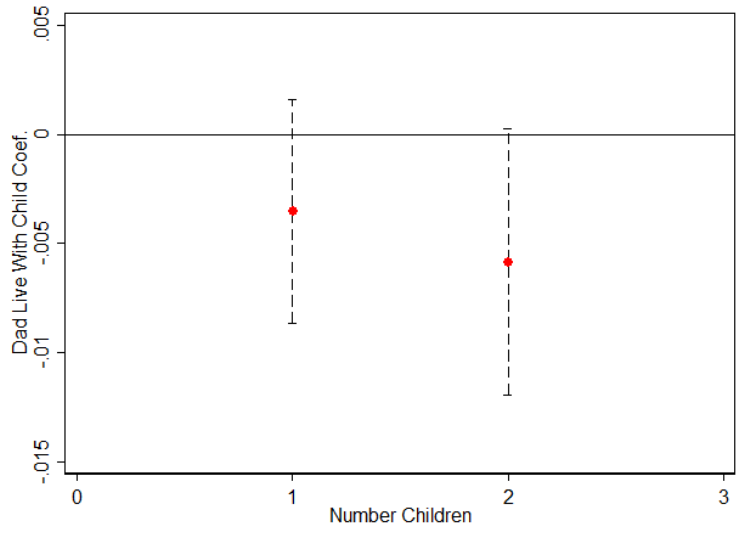

Notes: These figures show the coefficients and $95 \%$ confidence intervals from separate IV regressions by year of separation (sub-figure a), 50K DKK income bin (sub-figure b), and number of children (sub-figure c). The outcome is an indicator for the father ever residing with his child post-separation. Units are 1000s of real year 2000 DKK. 
Figure A9: IV Coefficients by Year, 50K Income Bin, and Number of Children for Father Has More Kids as Outcome

(a) By Year of Separation

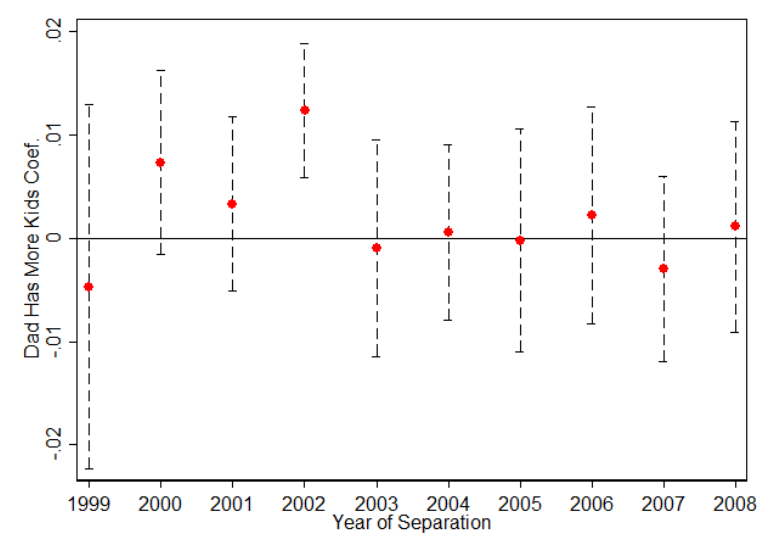

(b) By 50K Income Bin

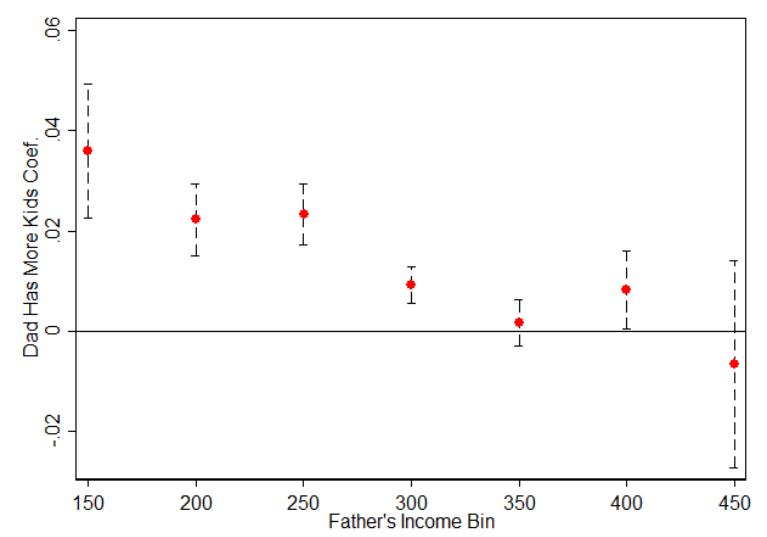

(c) By Number of Children

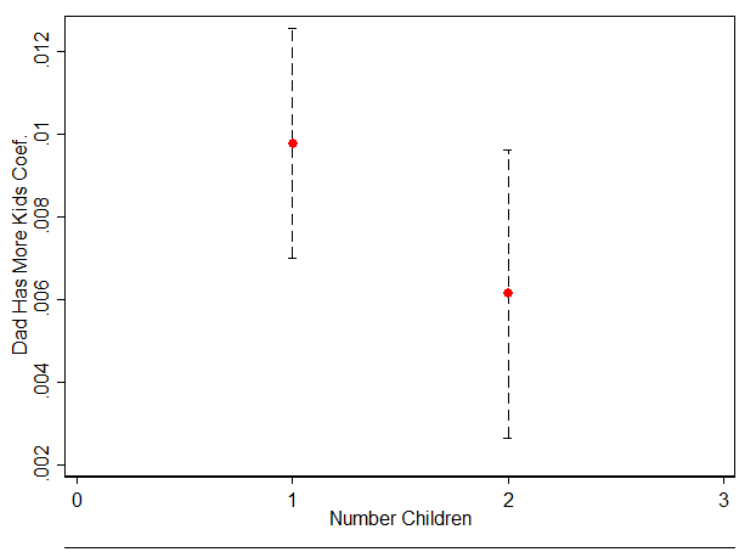

Notes: These figures show the coefficients and $95 \%$ confidence intervals from separate IV regressions by year of separation (sub-figure a), 50K DKK income bin (sub-figure b), and number of children (sub-figure c). The outcome is an indicator for the father having more children post-separation. Units are 1000s of real year 2000 DKK. 
Figure A10: IV Coefficients by Year, 50K Income Bin, and Number of Children for Mother Has More Kids as Outcome

(a) By Year of Separation

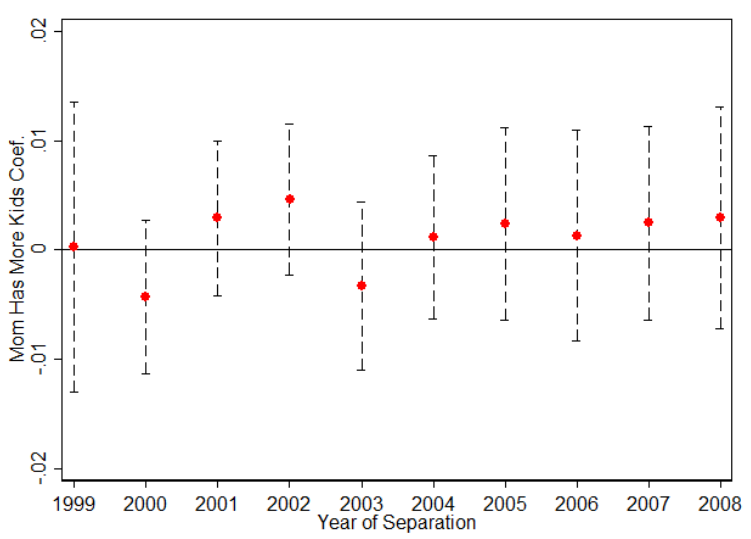

(b) By 50K Income Bin

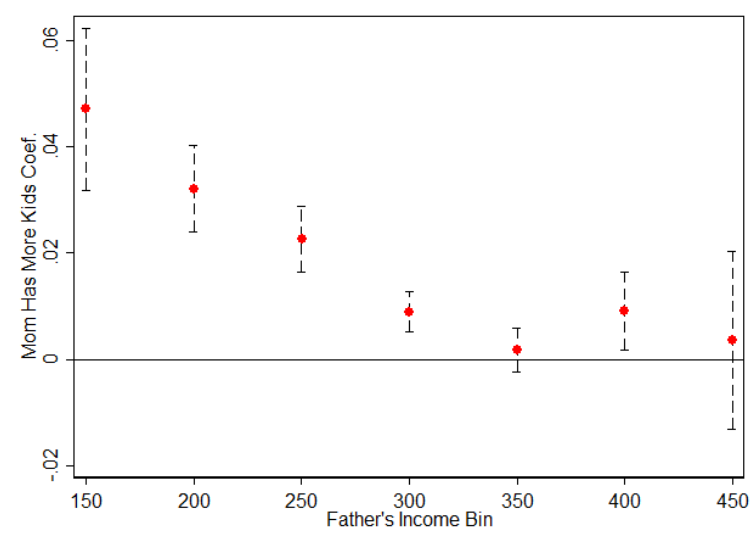

(c) By Number of Children

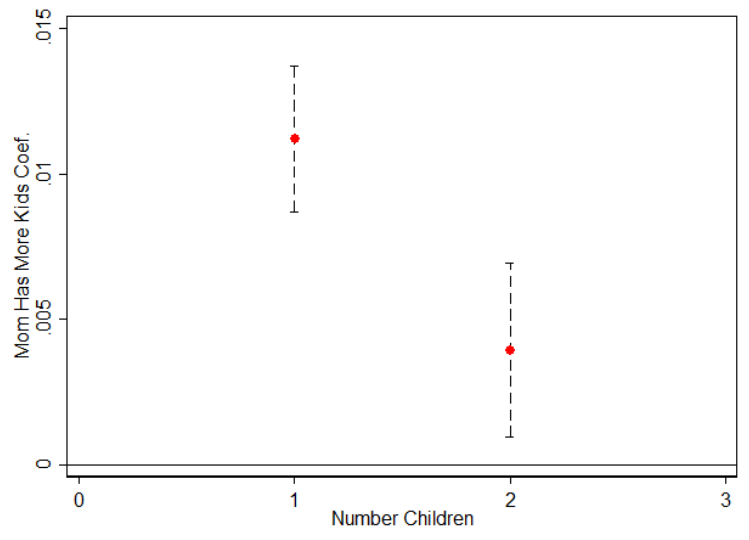

Notes: These figures show the coefficients and $95 \%$ confidence intervals from separate IV regressions by year of separation (sub-figure a), 50K DKK income bin (sub-figure b), and number of children (sub-figure c). The outcome is an indicator for the mother having more children post-separation. Units are 1000s of real year 2000 DKK. 
Figure A11: IV Coefficients by Year, 50K Income Bin, and Number of Children for Father is NILF as Outcome

(a) By Year of Separation

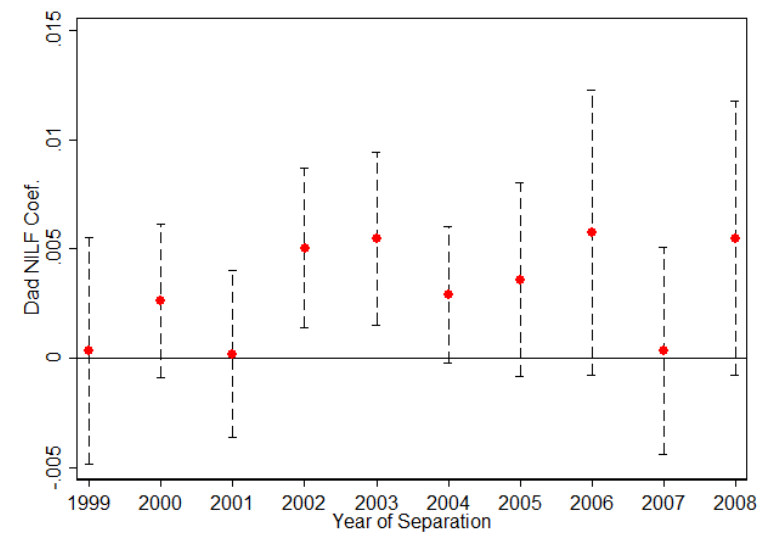

(b) By 50K Income Bin

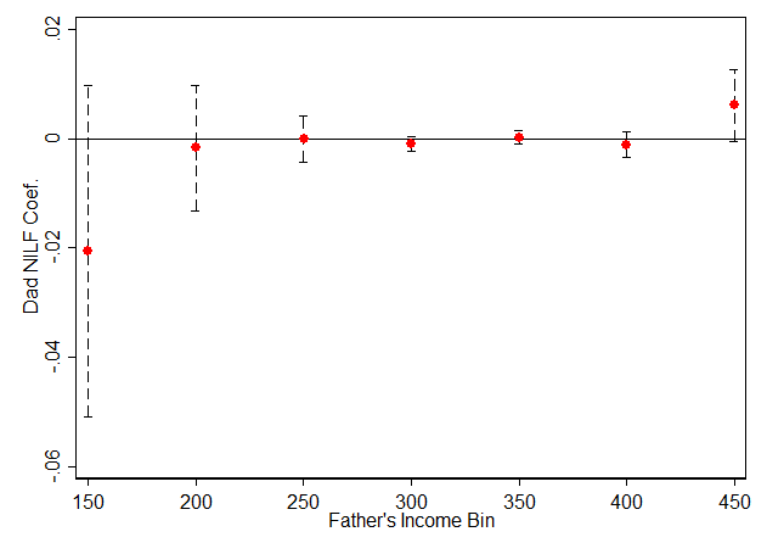

(c) By Number of Children

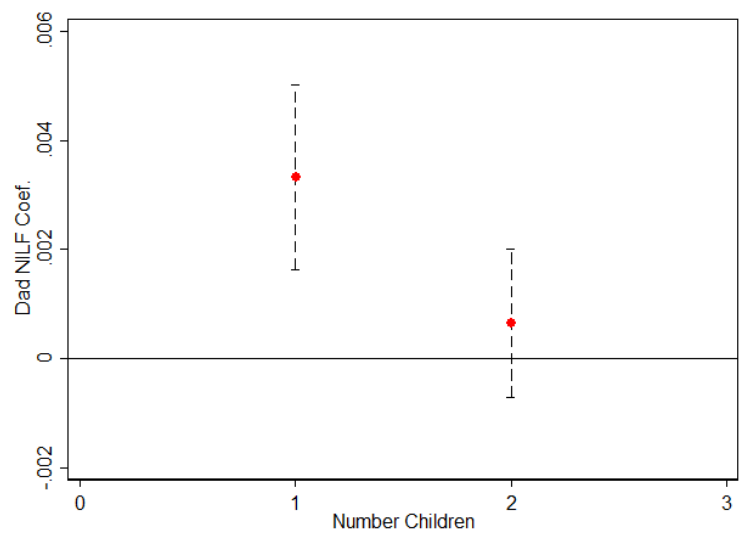

Notes: These figures show the coefficients and $95 \%$ confidence intervals from separate IV regressions by year of separation (sub-figure a), 50K DKK income bin (sub-figure b), and number of children (sub-figure c). The outcome is the average number of years that the father is not in the labor force (NILF) post-separation. Units are 1000s of real year 2000 DKK. 
Table A1: Child Support Obligation Schemes: 1999, 2005, 2008

\begin{tabular}{lll}
\hline 1999: Normal Amount = 9,132 DKK; Extra Amount = 0 DKK & \\
\hline Obligation & Income Range (1 Child) & Income Range (2 Children) \\
\hline Normal & $<=275,000$ & $<=290,000$ \\
Normal $+25 \% \times$ Normal & $275,001-290,000$ & $290,001-315,000$ \\
Normal $+50 \% \times$ Normal & $290,001-315,000$ & $315,001-355,000$ \\
Normal $+100 \% \times$ Normal & $>315,000$ & $>355,000$ \\
& & \\
\hline $\mathbf{2 0 0 5}$ Normal Amount $=\mathbf{1 0 , 8 2 4}$ DKK; Extra Amount = 1,392 DKK \\
\hline Obligation & Income Range $(1$ Child $)$ & Income Range $(2$ Children) \\
\hline Normal + Extra & $<=325,000$ & $<=345,000$ \\
Normal + Extra $+25 \% \times$ Normal & $325,001-345,000$ & $345,001-380,000$ \\
Normal + Extra $+50 \% \times$ Normal & $345,001-380,000$ & $380,001-420,000$ \\
Normal + Extra $+100 \% \times$ Normal & $380,001-500,000$ & $420,001-600,000$ \\
Normal + Extra $+200 \% \times$ Normal & $500,001-900,000$ & $600,001-1,100,000$ \\
Normal + Extra $+300 \% \times$ Normal & $>900,000$ & $>1,100,000$
\end{tabular}

\section{8: Normal Amount $=11,628$ DKK; Extra Amount $=1,500$ DKK}

\begin{tabular}{lll}
\hline Obligation & Income Range $(1$ Child $)$ & Income Range $(2$ Children) \\
\hline Normal + Extra & $<=350,000$ & $<=370,000$ \\
Normal + Extra $+25 \% \times$ Normal & $350,001-370,000$ & $370,001-405,000$ \\
Normal + Extra $+50 \% \times$ Normal & $370,001-405,000$ & $405,001-450,000$ \\
Normal + Extra $+100 \% \times$ Normal & $405,001-600,000$ & $450,001-700,000$ \\
Normal + Extra $+200 \% \times$ Normal & $600,001-1,000,000$ & $700,001-1,200,000$ \\
Normal + Extra $+300 \% \times$ Normal & $>1,000,000$ & $>1,200,000$
\end{tabular}

Notes: Information on the child support schemes comes from from Statsforvaltningen. For more information, please see http://www.statsforvaltningen.dk/site.aspx?p=6404. 


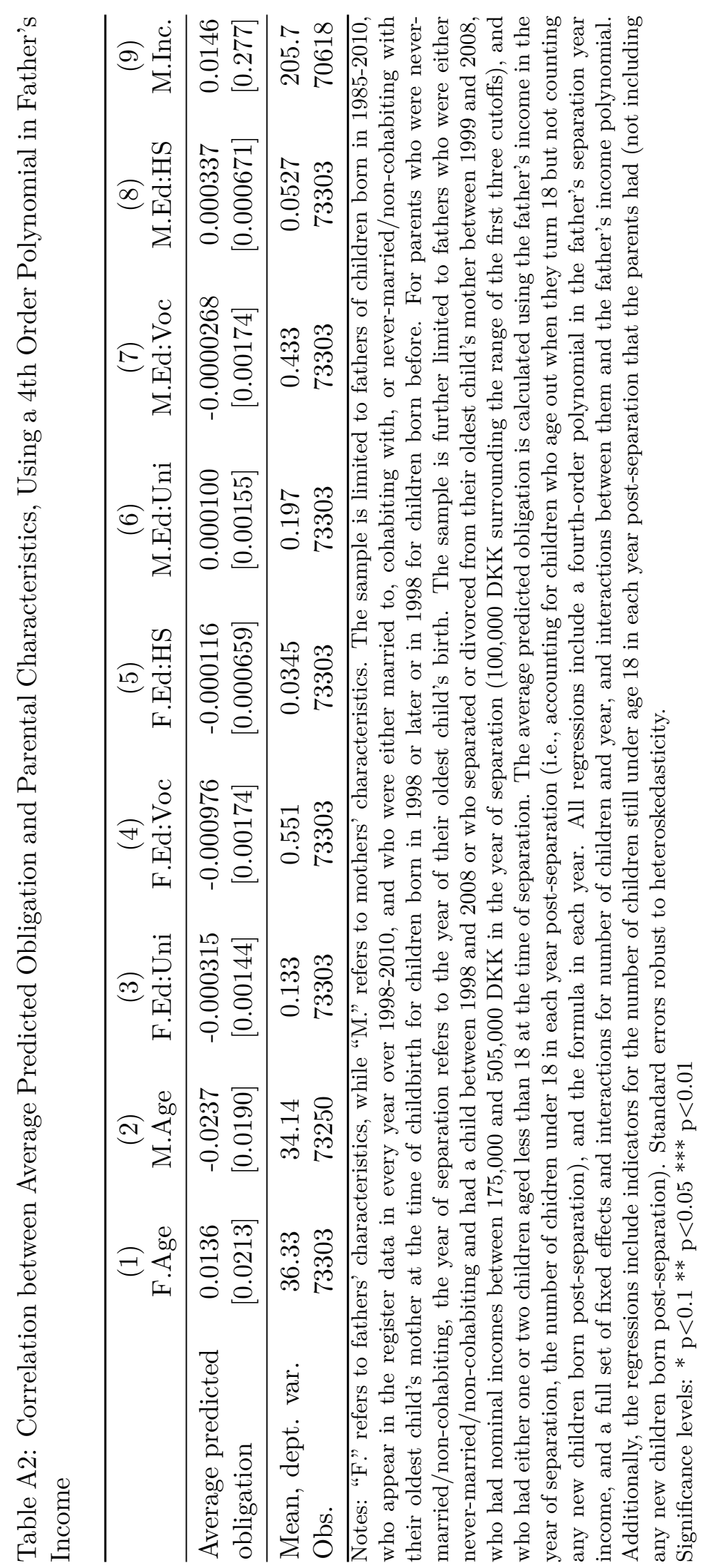


Table A3: Summary Statistics
(1)
$(2)$
(3)
$(4)$
(5)

All Sep. Prev. Mar. Prev. Coh. Never Mar/Coh All Parents

\begin{tabular}{|c|c|c|c|c|c|}
\hline $\begin{array}{l}\text { Average child } \\
\text { support paid }\end{array}$ & $\begin{array}{c}9.213 \\
(8.508)\end{array}$ & $\begin{array}{l}10.20 \\
(9.528)\end{array}$ & $\begin{array}{c}9.030 \\
(7.710)\end{array}$ & $\begin{array}{c}5.735 \\
(5.136)\end{array}$ & - \\
\hline $\begin{array}{l}\text { Average tax-ded. } \\
\text { obligation, current income/number kids }\end{array}$ & $\begin{array}{c}18.10 \\
(8.578)\end{array}$ & $\begin{array}{c}18.60 \\
(9.482)\end{array}$ & $\begin{array}{c}18.35 \\
(7.939)\end{array}$ & $\begin{array}{c}15.10 \\
(5.779)\end{array}$ & - \\
\hline $\begin{array}{l}\text { Average predicted } \\
\text { tax-ded. obligation }\end{array}$ & $\begin{array}{c}15.14 \\
(7.120)\end{array}$ & $\begin{array}{l}15.84 \\
(7.844)\end{array}$ & $\begin{array}{l}15.42 \\
(6.707)\end{array}$ & $\begin{array}{l}11.15 \\
(2.788)\end{array}$ & - \\
\hline $\begin{array}{l}\text { 1st child's age at } \\
\text { sep. }\end{array}$ & $\begin{array}{c}6.925 \\
(5.585)\end{array}$ & $\begin{array}{c}9.649 \\
(5.420)\end{array}$ & $\begin{array}{c}5.685 \\
(4.333)\end{array}$ & $\begin{array}{c}0 \\
(0)\end{array}$ & $\begin{array}{c}8.572 \\
(9.214)\end{array}$ \\
\hline Dad age at sep. & $\begin{array}{c}36.33 \\
(7.581)\end{array}$ & $\begin{array}{c}39.69 \\
(7.059)\end{array}$ & $\begin{array}{c}34.34 \\
(6.533)\end{array}$ & $\begin{array}{c}29.50 \\
(5.972)\end{array}$ & $\begin{array}{c}38.67 \\
(10.04)\end{array}$ \\
\hline Dad inc. at sep. & $\begin{array}{c}286.3 \\
(71.92)\end{array}$ & $\begin{array}{c}298.6 \\
(72.88)\end{array}$ & $\begin{array}{c}279.7 \\
(68.74)\end{array}$ & $\begin{array}{c}258.6 \\
(68.45)\end{array}$ & $\begin{array}{c}307.7 \\
(273.8)\end{array}$ \\
\hline Dad ed: uni/college & $\begin{array}{c}0.133 \\
(0.339)\end{array}$ & $\begin{array}{c}0.161 \\
(0.368)\end{array}$ & $\begin{array}{c}0.111 \\
(0.314)\end{array}$ & $\begin{array}{l}0.0939 \\
(0.292)\end{array}$ & $\begin{array}{c}0.205 \\
(0.404)\end{array}$ \\
\hline $\begin{array}{l}\text { Dad ed: short } \\
\text { high-ed/vocational }\end{array}$ & $\begin{array}{c}0.551 \\
(0.497)\end{array}$ & $\begin{array}{c}0.565 \\
(0.496)\end{array}$ & $\begin{array}{c}0.554 \\
(0.497)\end{array}$ & $\begin{array}{c}0.476 \\
(0.499)\end{array}$ & $\begin{array}{c}0.470 \\
(0.499)\end{array}$ \\
\hline Dad ed: high school & $\begin{array}{l}0.0345 \\
(0.183)\end{array}$ & $\begin{array}{l}0.0355 \\
(0.185)\end{array}$ & $\begin{array}{l}0.0303 \\
(0.171)\end{array}$ & $\begin{array}{l}0.0463 \\
(0.210)\end{array}$ & $\begin{array}{l}0.0513 \\
(0.221)\end{array}$ \\
\hline Mom age at sep. & $\begin{array}{c}34.14 \\
(7.111)\end{array}$ & $\begin{array}{c}37.18 \\
(6.334)\end{array}$ & $\begin{array}{c}32.40 \\
(6.497)\end{array}$ & $\begin{array}{c}27.78 \\
(5.934)\end{array}$ & $\begin{array}{c}36.14 \\
(9.359)\end{array}$ \\
\hline Mom inc. at sep. & $\begin{array}{c}205.7 \\
(73.18)\end{array}$ & $\begin{array}{c}224.7 \\
(73.07)\end{array}$ & $\begin{array}{c}196.3 \\
(68.48)\end{array}$ & $\begin{array}{c}161.2 \\
(63.97)\end{array}$ & $\begin{array}{c}211.0 \\
(136.9)\end{array}$ \\
\hline Mom ed: uni/college & $\begin{array}{c}0.197 \\
(0.398)\end{array}$ & $\begin{array}{c}0.231 \\
(0.422)\end{array}$ & $\begin{array}{c}0.176 \\
(0.381)\end{array}$ & $\begin{array}{c}0.133 \\
(0.339)\end{array}$ & $\begin{array}{c}0.263 \\
(0.440)\end{array}$ \\
\hline $\begin{array}{l}\text { Mom ed: short } \\
\text { high-ed/vocational }\end{array}$ & $\begin{array}{c}0.433 \\
(0.495)\end{array}$ & $\begin{array}{c}0.481 \\
(0.500)\end{array}$ & $\begin{array}{c}0.417 \\
(0.493)\end{array}$ & $\begin{array}{c}0.287 \\
(0.452)\end{array}$ & $\begin{array}{c}0.368 \\
(0.482)\end{array}$ \\
\hline Mom ed: high school & $\begin{array}{l}0.0527 \\
(0.223)\end{array}$ & $\begin{array}{l}0.0453 \\
(0.208)\end{array}$ & $\begin{array}{l}0.0545 \\
(0.227)\end{array}$ & $\begin{array}{l}0.0769 \\
(0.266)\end{array}$ & $\begin{array}{l}0.0680 \\
(0.252)\end{array}$ \\
\hline Obs. & 73,303 & 34,656 & 30,466 & 8,181 & 866,038 \\
\hline
\end{tabular}

Notes: All income variables are in year 2000 real units of 1,000 DKK. In columns (1)-(4), the sample is limited to fathers of children born in 1985-2010, who appear in the register data in every year over 1998-2010, and who were either married to, cohabiting with, or never-married/non-cohabiting with their oldest child's mother at the time of childbirth for children born in 1998 or later or in 1998 for children born before. For parents who were never-married/non-cohabiting, the year of separation refers to the year of their oldest child's birth. The sample is further limited to fathers who were either never-married/noncohabiting and had a child between 1998 and 2008 or who separated or divorced from their oldest child's mother between 1999 and 2008, who had nominal incomes between 175,000 and 505,000 DKK in the year of separation (100,000 DKK surrounding the range of the first three thresholds), and who had either one or two children aged less than 18 at the time of separation. Column (5) reports summary statistics for all parents of children born in 1985-2010 who appear in the register data over 1998-2010. There is no year of separation for these families; the statistics reported are averages over 1998-2010. 
Table A4: Child Support Payment Variables, More Details

\begin{tabular}{|c|c|c|c|c|}
\hline & $\begin{array}{c}(1) \\
\text { All Sep. }\end{array}$ & $\begin{array}{c}(2) \\
\text { Prev. Mar. }\end{array}$ & $\begin{array}{c}(3) \\
\text { Prev. Coh. }\end{array}$ & $\begin{array}{c}(4) \\
\text { Never Mar/Coh }\end{array}$ \\
\hline $\begin{array}{l}\text { CS Paid as Pct. of } \\
\text { Obligation }\end{array}$ & 0.515 & 0.561 & 0.491 & 0.409 \\
\hline Zero CS Paid & 0.193 & 0.190 & 0.175 & 0.272 \\
\hline $\begin{array}{l}\text { CS Paid as Pct. of } \\
\text { Obligation, no 0s }\end{array}$ & 0.638 & 0.693 & 0.595 & 0.562 \\
\hline $\begin{array}{l}0<\text { CS Paid }< \\
\text { Obligation }\end{array}$ & 0.731 & 0.704 & 0.772 & 0.696 \\
\hline $\begin{array}{l}\text { CS Paid }>= \\
\text { Obligation }\end{array}$ & 0.0757 & 0.106 & 0.0529 & 0.0317 \\
\hline Obs. & 73,303 & 34,656 & 30,466 & 8,181 \\
\hline
\end{tabular}


Table A5: First Stage, Average Predicted Obligations and Actual Average Obligations

\begin{tabular}{lccccc}
\hline & \multicolumn{5}{c}{ Dep. Var.: } \\
\cline { 2 - 6 } & $(1)$ & $(2)$ & $(3)$ & $(4)$ & $(5)$ \\
& Poly 1 & Poly 2 & Poly 3 & Poly 4 & $20 \mathrm{~K}$ Bins \\
\hline Average predicted & $0.597^{* * *}$ & $0.695^{* * *}$ & $0.639^{* * *}$ & $0.744^{* * *}$ & $0.851^{* * *}$ \\
obligation & {$[0.00841]$} & {$[0.0149]$} & {$[0.0151]$} & {$[0.0174]$} & {$[0.0178]$} \\
\hline Mean, dept. var. & 19.91 & 19.91 & 19.91 & 19.91 & 19.91 \\
Obs. & 70468 & 70468 & 70468 & 70468 & 70468 \\
F-stat & 5032.2 & 2188.2 & 1783.3 & 1832.7 & 2291.7 \\
R-squared & 0.749 & 0.750 & 0.753 & 0.754 & 0.756 \\
\hline
\end{tabular}

Notes: Predicted and actual obligations as well as all income variables are reported in 1000s of real year 2000 DKK. This table reports results from a first stage regression of actual average obligations (calculated using fathers' current incomes and numbers of children in each year post-separation) on average predicted obligations (calculated using fathers' separation year incomes and numbers of children). See notes under Table 2 for more information on the sample. The following functions of the father's real income in the year of separation are included: column 1 - linear polynomial, column 2 - quadratic polynomial, column 3 cubic polynomial, column 4 - quartic polynomial, column 5 - indicators for 20,000 DKK bins. All regressions include a full set of fixed effects and interactions for number of children, year of separation, and the interactions between them and the father's income function. All regressions include controls (measured in the year of separation) for the father's age and age squared, dummies for the father's education (less than high school, high school, vocational/short-term higher ed, college/university, and missing), an indicator for the father being from Western Europe, mother's age and age squared, dummies for the mother's education (less than high school, high school, vocational/short-term higher ed, college/university, and missing), an indicator for the mother being from Western Europe, mother's total income in year 2000 DKK, oldest child's age and age squared, youngest child's age and age squared, an indicator for the oldest child being male, an indicator for the youngest child being male, and indicators for original parental relationship status (married, cohabiting, never-married/non-cohabiting). Additionally, the regressions include indicators for the number of children still under age 18 in each year post-separation that the parents had (not including any new children born post-separation). Standard errors robust to heteroskedasticity.

Significance levels: $* \mathrm{p}<0.1 * * \mathrm{p}<0.05 * * * \mathrm{p}<0.01$ 
Table A6: IV Effects of Average Child Support Obligations on Mothers' Post-Separation Labor Market Outcomes

\begin{tabular}{lccccc}
\hline & $(1)$ & $(2)$ & $(3)$ & $(4)$ & $(5)$ \\
& Any Wage & Log Wage & Emp. & Self-Emp. & NILF \\
\hline Average child & 0.000843 & $0.00894^{*}$ & 0.00122 & 0.000443 & 0.000699 \\
support obligation & {$[0.00101]$} & {$[0.00460]$} & {$[0.00117]$} & {$[0.000586]$} & {$[0.000822]$} \\
\hline Mean, dept. var. & 0.848 & 11.82 & 0.753 & 0.0237 & 0.0690 \\
Fst. Stage Coef. & 0.853 & 0.842 & 0.852 & 0.852 & 0.852 \\
Fst. Stage F-Stat & 2277.7 & 2105.2 & 2280.6 & 2280.6 & 2280.6 \\
Obs. & 68700 & 65366 & 68772 & 68772 & 68772
\end{tabular}

Notes: The outcomes are defined as follows: 1) "Any Wage" refers to the proportion of years the mother has any wage income post-separation, 2) "Log Wage" refers to the log of the mother's average annual wage income in the years post-separation, 3) "Emp." refers to the proportion of years the mother is employed in the private or public sector (not self-employed) postseparation, 4) "Self-Emp." refers to the proportion of years the mother is self-employed post-separation, and 5) "NILF" refers to the proportion of years the mother is not in the labor force post-separation. All income variables are in year 2000 real units of 1,000 DKK. See notes under Tables 2 and 3 for more information on the sample, specifications, and controls. Standard errors robust to heteroskedasticity.

Significance levels: $* \mathrm{p}<0.1 * * \mathrm{p}<0.05 * * * \mathrm{p}<0.01$ 


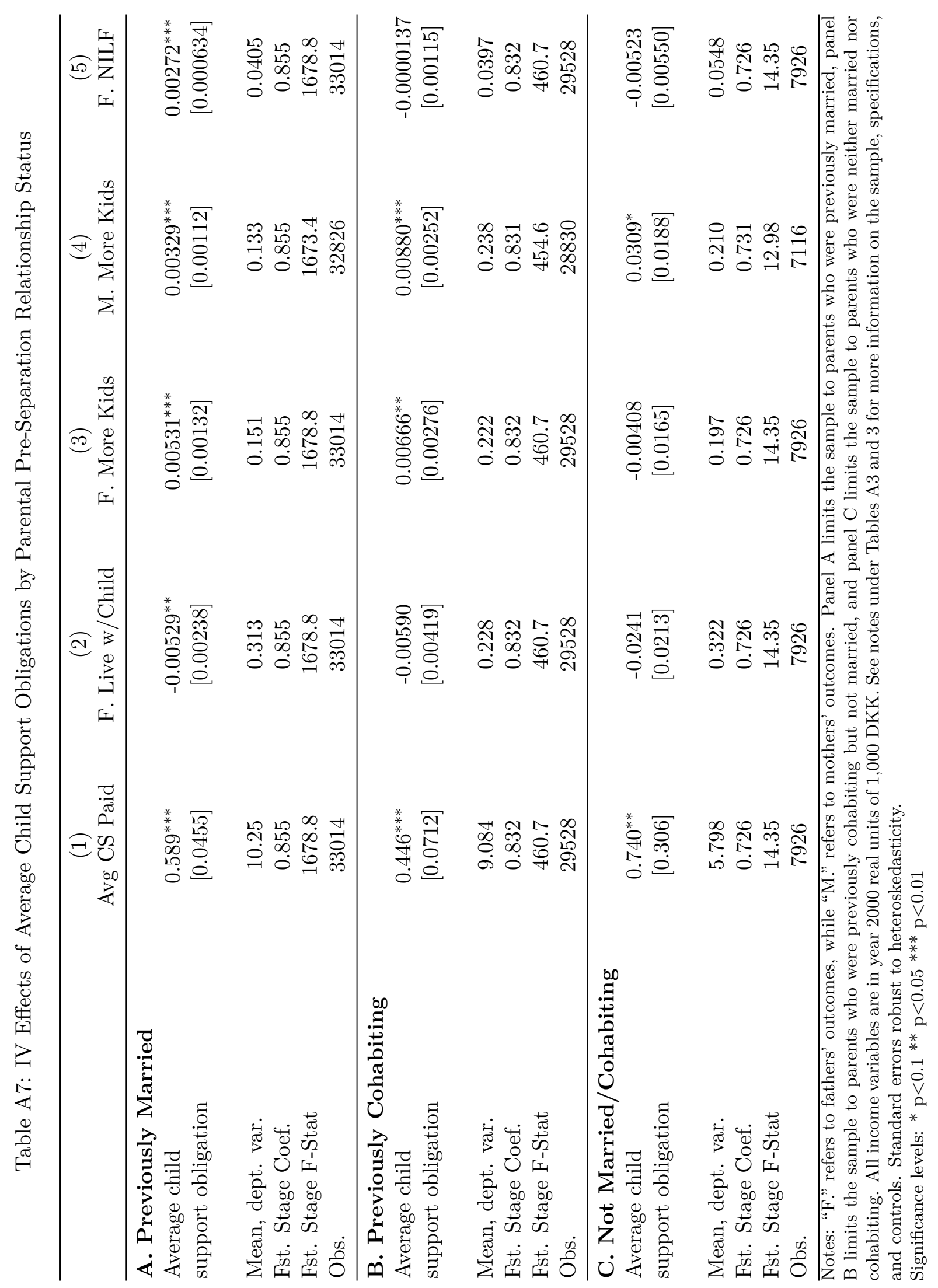


Table A8: IV Effects of Average Child Support Obligations on Main Outcomes, Different Polynomial Specifications

(1)

Avg CS Paid
$(2)$

F. Live w/Child
(3)

F. More Kids
(4)

M. More Kids
(5)

F. NILF

\begin{tabular}{|c|c|c|c|c|c|}
\hline \multicolumn{6}{|l|}{ A. Poly 1} \\
\hline Average child & $0.445^{* * *}$ & -0.00172 & 0.000735 & 0.00150 & $0.0105^{* * *}$ \\
\hline support obligation & {$[0.0253]$} & {$[0.00122]$} & {$[0.000966]$} & {$[0.000912]$} & [0.000438] \\
\hline Mean, dept. var. & 9.263 & 0.278 & 0.186 & 0.185 & 0.0418 \\
\hline Fst. Stage Coef. & 0.597 & 0.597 & 0.597 & 0.596 & 0.597 \\
\hline Fst. Stage F-Stat & 5032.2 & 5032.2 & 5032.2 & 4910.8 & 5032.2 \\
\hline Obs. & 70468 & 70468 & 70468 & 68772 & 70468 \\
\hline \multicolumn{6}{|l|}{ B. Poly 2} \\
\hline Average child & $0.525^{* * *}$ & $-0.00664^{* * *}$ & $0.00393^{* * *}$ & $0.00412^{* * *}$ & 0.000604 \\
\hline support obligation & {$[0.0359]$} & {$[0.00185]$} & {$[0.00127]$} & {$[0.00113]$} & {$[0.000517]$} \\
\hline Mean, dept. var. & 9.263 & 0.278 & 0.186 & 0.185 & 0.0418 \\
\hline Fst. Stage Coef. & 0.695 & 0.695 & 0.695 & 0.698 & 0.695 \\
\hline Fst. Stage F-Stat & 2188.2 & 2188.2 & 2188.2 & 2171.7 & 2188.2 \\
\hline Obs. & 70468 & 70468 & 70468 & 68772 & 70468 \\
\hline \multicolumn{6}{|l|}{ C. Poly 3} \\
\hline Average child & $0.571^{* * *}$ & $-0.00609^{* * *}$ & $0.00382^{* * *}$ & $0.00459^{* * *}$ & -0.000864 \\
\hline support obligation & {$[0.0403]$} & {$[0.00212]$} & {$[0.00142]$} & {$[0.00127]$} & {$[0.000599]$} \\
\hline Mean, dept. var. & 9.263 & 0.278 & 0.186 & 0.185 & 0.0418 \\
\hline Fst. Stage Coef. & 0.639 & 0.639 & 0.639 & 0.640 & 0.639 \\
\hline Fst. Stage F-Stat & 1783.3 & 1783.3 & 1783.3 & 1764.7 & 1783.3 \\
\hline Obs. & 70468 & 70468 & 70468 & 68772 & 70468 \\
\hline \multicolumn{6}{|l|}{ D. Poly 4} \\
\hline Average child & $0.540^{* * *}$ & $-0.00735^{* * *}$ & $0.00761^{* * *}$ & $0.00685^{* * *}$ & $0.00273^{* * *}$ \\
\hline support obligation & {$[0.0403]$} & {$[0.00224]$} & {$[0.00127]$} & {$[0.00115]$} & {$[0.000647]$} \\
\hline Mean, dept. var. & 9.263 & 0.278 & 0.186 & 0.185 & 0.0418 \\
\hline Fst. Stage Coef. & 0.744 & 0.744 & 0.744 & 0.748 & 0.744 \\
\hline Fst. Stage F-Stat & 1832.7 & 1832.7 & 1832.7 & 1831.9 & 1832.7 \\
\hline Obs. & 70468 & 70468 & 70468 & 68772 & 70468 \\
\hline
\end{tabular}

Notes: "F." refers to fathers' outcomes, while "M." refers to mothers' outcomes. Each coefficient in each panel is from a separate regression. All income variables are in year 2000 real units of 1,000 DKK. The following functions of the father's real income in the separation year are included: Panel A - linear polynomial, Panel B - quadratic polynomial, Panel C — cubic polynomial, Panel D - quartic polynomial. All regressions include the controls listed in the notes under Table 3 and a full set of fixed effects and interactions for number of children, year of separation, and the interactions between them and the father's income function. Additionally, the regressions include indicators for the number of children still under age 18 in each year post-separation that the parents had (not including any new children born post-separation). Standard errors robust to heteroskedasticity.

Significance levels: ${ }^{*} \mathrm{p}<0.1{ }^{* *} \mathrm{p}<0.05^{* * *} \mathrm{p}<0.01$ 
Table A9: IV Effects of Average Child Support Obligations on Main Outcomes, Different Bin Specifications

\begin{tabular}{|c|c|c|c|c|c|}
\hline & $\begin{array}{c}(1) \\
\text { Avg CS Paid }\end{array}$ & F. Live $\mathrm{w} /$ Child & $\begin{array}{c}(3) \\
\text { F. More Kids }\end{array}$ & $\begin{array}{c}(4) \\
\text { M. More Kids }\end{array}$ & F. NILF \\
\hline $\begin{array}{l}\text { A. } 50 K \text { Bins } \\
\text { Average child } \\
\text { support obligation }\end{array}$ & $\begin{array}{l}0.513^{* * *} \\
{[0.0330]}\end{array}$ & $\begin{array}{c}-0.00444^{* * *} \\
{[0.00163]}\end{array}$ & $\begin{array}{c}0.00533^{* * *} \\
{[0.00106]}\end{array}$ & $\begin{array}{l}0.00441^{* * *} \\
{[0.000969]}\end{array}$ & $\begin{array}{l}0.00134^{* * *} \\
{[0.000420]}\end{array}$ \\
\hline $\begin{array}{l}\text { Mean, dept. var. } \\
\text { Fst. Stage Coef. } \\
\text { Fst. Stage F-Stat } \\
\text { Obs. }\end{array}$ & $\begin{array}{c}9.263 \\
0.797 \\
2950.0 \\
70468\end{array}$ & $\begin{array}{c}0.278 \\
0.797 \\
2950.0 \\
70468\end{array}$ & $\begin{array}{c}0.186 \\
0.797 \\
2950.0 \\
70468\end{array}$ & $\begin{array}{c}0.185 \\
0.799 \\
2922.6 \\
68772\end{array}$ & $\begin{array}{c}0.0418 \\
0.797 \\
2950.0 \\
70468\end{array}$ \\
\hline $\begin{array}{l}\text { B. } 25 K \text { Bins } \\
\text { Average child } \\
\text { support obligation }\end{array}$ & $\begin{array}{l}0.525^{* * *} \\
{[0.0371]}\end{array}$ & $\begin{array}{c}-0.00577^{* * *} \\
{[0.00199]}\end{array}$ & $\begin{array}{c}0.00572^{* * *} \\
{[0.00116]}\end{array}$ & $\begin{array}{c}0.00589^{* * *} \\
{[0.00101]}\end{array}$ & $\begin{array}{l}0.00239^{* * *} \\
{[0.000547]}\end{array}$ \\
\hline $\begin{array}{l}\text { Mean, dept. var. } \\
\text { Fst. Stage Coef. } \\
\text { Fst. Stage F-Stat } \\
\text { Obs. }\end{array}$ & $\begin{array}{c}9.263 \\
0.820 \\
2227.3 \\
70468\end{array}$ & $\begin{array}{c}0.278 \\
0.820 \\
2227.3 \\
70468\end{array}$ & $\begin{array}{c}0.186 \\
0.820 \\
2227.3 \\
70468\end{array}$ & $\begin{array}{c}0.185 \\
0.821 \\
2213.2 \\
68772\end{array}$ & $\begin{array}{c}0.0418 \\
0.820 \\
2227.3 \\
70468\end{array}$ \\
\hline $\begin{array}{l}\text { C. } \mathbf{1 5 K} \text { Bins } \\
\text { Average child } \\
\text { support obligation }\end{array}$ & $\begin{array}{l}0.512^{* * *} \\
{[0.0373]}\end{array}$ & $\begin{array}{c}-0.00713^{* * *} \\
{[0.00207]}\end{array}$ & $\begin{array}{c}0.00739^{* * *} \\
{[0.00114]}\end{array}$ & $\begin{array}{l}0.00680^{* * *} \\
{[0.000996]}\end{array}$ & $\begin{array}{l}0.00283^{* * *} \\
{[0.000576]}\end{array}$ \\
\hline $\begin{array}{l}\text { Mean, dept. var. } \\
\text { Fst. Stage Coef. } \\
\text { Fst. Stage F-Stat } \\
\text { Obs. }\end{array}$ & $\begin{array}{c}9.263 \\
0.857 \\
2175.5 \\
70468\end{array}$ & $\begin{array}{c}0.278 \\
0.857 \\
2175.5 \\
70468\end{array}$ & $\begin{array}{c}0.186 \\
0.857 \\
2175.5 \\
70468\end{array}$ & $\begin{array}{c}0.185 \\
0.859 \\
2169.3 \\
68772\end{array}$ & $\begin{array}{c}0.0418 \\
0.857 \\
2175.5 \\
70468\end{array}$ \\
\hline $\begin{array}{l}\text { D. } \mathbf{1 0 K} \text { Bins } \\
\text { Average child } \\
\text { support obligation }\end{array}$ & $\begin{array}{l}0.524^{* * *} \\
{[0.0378]}\end{array}$ & $\begin{array}{c}-0.00592^{* * *} \\
{[0.00211]}\end{array}$ & $\begin{array}{c}0.00735^{* * *} \\
{[0.00114]}\end{array}$ & $\begin{array}{l}0.00696^{* * *} \\
{[0.000987]}\end{array}$ & $\begin{array}{l}0.00265^{* * *} \\
{[0.000593]}\end{array}$ \\
\hline $\begin{array}{l}\text { Mean, dept. var. } \\
\text { Fst. Stage Coef. } \\
\text { Fst. Stage F-Stat } \\
\text { Obs. }\end{array}$ & $\begin{array}{c}9.263 \\
0.866 \\
2089.2 \\
70468\end{array}$ & $\begin{array}{c}0.278 \\
0.866 \\
2089.2 \\
70468\end{array}$ & $\begin{array}{c}0.186 \\
0.866 \\
2089.2 \\
70468\end{array}$ & $\begin{array}{c}0.185 \\
0.866 \\
2082.0 \\
68772\end{array}$ & $\begin{array}{c}0.0418 \\
0.866 \\
2089.2 \\
70468\end{array}$ \\
\hline
\end{tabular}

Notes: "F." refers to fathers' outcomes, while "M." refers to mothers' outcomes. Each coefficient in each panel is from a separate regression. All income variables are in year 2000 real units of 1,000 DKK. The following functions of the father's real income in the year of separation are included: Panel A - indicators for 50,000 DKK bins, Panel B - indicators for 25,000 DKK bins, Panel C - indicators for 15,000 DKK bins, Panel D - indicators for 10,000 DKK bins. All regressions include the controls listed in the notes under Table 3 as well as a full set of fixed effects and interactions for number of children, year of separation, and the interactions between them and the father's income function. Additionally, the regressions include indicators for the number of children still under age 18 in each year post-separation that the parents had (not including any new children born post-separation). Standard errors robust to heteroskedasticity.

Significance levels: $* \mathrm{p}<0.1 * * \mathrm{p}<0.05 * * * \mathrm{p}<0.01$ 
Table A10: IV Results Using Narrow Windows Surrounding First Threshold

$(3)$

(4)

(5)

Avg CS Paid F. Live w/Child F. More Kids M. More Kids F. NILF

\begin{tabular}{|c|c|c|c|c|c|}
\hline \\
\hline \multirow{2}{*}{$\begin{array}{l}\text { A. } 20 \mathrm{~K} \text { Window } \\
\text { Average child } \\
\text { support obligation }\end{array}$} & $0.374^{* * *}$ & -0.00493 & $0.0196^{* * *}$ & $0.0201^{* * *}$ & $-0.00279^{*}$ \\
\hline & {$[0.0731]$} & {$[0.00621]$} & {$[0.00295]$} & {$[0.00295]$} & {$[0.00163]$} \\
\hline Mean, dept. var. & 8.928 & 0.284 & 0.193 & 0.186 & 0.0261 \\
\hline Fst. Stage Coef. & 1.355 & 1.355 & 1.355 & 1.359 & 1.355 \\
\hline Fst. Stage F-Stat & 462.8 & 462.8 & 462.8 & 460.3 & 462.8 \\
\hline Obs. & 13463 & 13463 & 13463 & 13190 & 13463 \\
\hline \multicolumn{6}{|l|}{ B. $40 \mathrm{~K}$ Window } \\
\hline \multirow{2}{*}{$\begin{array}{l}\text { Average child } \\
\text { support obligation }\end{array}$} & $0.410^{* * *}$ & -0.00277 & $0.0135^{* * *}$ & $0.0149^{* * *}$ & -0.00110 \\
\hline & {$[0.0605]$} & {$[0.00443]$} & {$[0.00232]$} & {$[0.00232]$} & {$[0.00112]$} \\
\hline \multirow{4}{*}{$\begin{array}{l}\text { Mean, dept. var. } \\
\text { Fst. Stage Coef. } \\
\text { Fst. Stage F-Stat } \\
\text { Obs. }\end{array}$} & 8.959 & 0.283 & 0.188 & 0.186 & 0.0267 \\
\hline & 1.167 & 1.167 & 1.167 & 1.170 & 1.167 \\
\hline & 837.4 & 837.4 & 837.4 & 832.0 & 837.4 \\
\hline & 26454 & 26454 & 26454 & 25895 & 26454 \\
\hline \multicolumn{6}{|l|}{ C. $60 \mathrm{~K}$ Window } \\
\hline \multirow{2}{*}{$\begin{array}{l}\text { Average child } \\
\text { support obligation }\end{array}$} & $0.450^{* * *}$ & -0.00451 & $0.0125^{* * *}$ & $0.0149^{* * *}$ & -0.00127 \\
\hline & {$[0.0506]$} & {$[0.00354]$} & {$[0.00196]$} & [0.00189] & {$[0.000856]$} \\
\hline \multirow{4}{*}{$\begin{array}{l}\text { Mean, dept. var. } \\
\text { Fst. Stage Coef. } \\
\text { Fst. Stage F-Stat } \\
\text { Obs. }\end{array}$} & 8.962 & 0.282 & 0.189 & 0.187 & 0.0283 \\
\hline & 1.119 & 1.119 & 1.119 & 1.124 & 1.119 \\
\hline & 1159.5 & 1159.5 & 1159.5 & 1155.0 & 1159.5 \\
\hline & 38295 & 38295 & 38295 & 37504 & 38295 \\
\hline \multicolumn{6}{|l|}{ D. 80K Window } \\
\hline \multirow{2}{*}{$\begin{array}{l}\text { Average child } \\
\text { support obligation }\end{array}$} & $0.411^{* * *}$ & -0.00168 & $0.0125^{* * *}$ & $0.0119^{* * *}$ & -0.0000544 \\
\hline & {$[0.0436]$} & {$[0.00298]$} & {$[0.00164]$} & {$[0.00158]$} & {$[0.000746]$} \\
\hline \multirow{4}{*}{$\begin{array}{l}\text { Mean, dept. var. } \\
\text { Fst. Stage Coef. } \\
\text { Fst. Stage F-Stat } \\
\text { Obs. }\end{array}$} & 8.979 & 0.282 & 0.189 & 0.188 & 0.0305 \\
\hline & 1.103 & 1.103 & 1.103 & 1.108 & 1.103 \\
\hline & 1498.8 & 1498.8 & 1498.8 & 1492.0 & 1498.8 \\
\hline & 47964 & 47964 & 47964 & 46946 & 47964 \\
\hline \multicolumn{6}{|l|}{ E. 100K Window } \\
\hline \multirow{2}{*}{$\begin{array}{l}\text { Average child } \\
\text { support obligation }\end{array}$} & $0.441^{* * *}$ & -0.00324 & $0.0110^{* * *}$ & $0.0105^{* * *}$ & 0.000601 \\
\hline & {$[0.0396]$} & {$[0.00261]$} & {$[0.00144]$} & {$[0.00134]$} & {$[0.000662]$} \\
\hline \multirow{4}{*}{$\begin{array}{l}\text { Mean, dept. var. } \\
\text { Fst. Stage Coef. } \\
\text { Fst. Stage F-Stat } \\
\text { Obs. }\end{array}$} & 8.999 & 0.280 & 0.190 & 0.190 & 0.0331 \\
\hline & 1.072 & 1.072 & 1.072 & 1.076 & 1.072 \\
\hline & 1816.2 & 1816.2 & 1816.2 & 1807.3 & 1816.2 \\
\hline & 55583 & 55583 & 55583 & 54334 & 55583 \\
\hline
\end{tabular}

Notes: "F." refers to fathers' outcomes, while "M." refers to mothers' outcomes. Each coefficient in each panel is from a separate regression. In each panel, the sample is limited to fathers with separation year incomes within the specified window of the first threshold in the child support formula. All income varidobes are in year 2000 real units of 1,000 DKK. See notes under Appendix Table A3 and Table 3 for more information on the sample, specifications, and controls. Standard errors robust to heteroskedasticity.

Significance levels: ${ }^{*} \mathrm{p}<0.1{ }^{* *} \mathrm{p}<0.05{ }^{* * *} \mathrm{p}<0.01$ 
Table A11: Robustness of IV Results

(1)

$(2)$

(3)

(4)

(5)

Avg CS Paid F. Live w/Child F. More Kids M. More Kids $\quad$ F. NILF

\begin{tabular}{lccccc}
\hline A. Using Father's Income in Year & Before Separation to Predict & Average Obligations \\
Average child & $0.539^{* * *}$ & $-0.00800^{* * *}$ & $0.00591^{* * *}$ & 0.00213 & $0.00200^{* * *}$ \\
support obligation & {$[0.0382]$} & {$[0.00211]$} & {$[0.00142]$} & {$[0.00132]$} & {$[0.000657]$} \\
& & & & & \\
Mean, dept. var. & 9.265 & 0.279 & 0.186 & 0.186 & 0.0403 \\
Fst. Stage Coef. & 0.701 & 0.701 & 0.701 & 0.706 & 0.701 \\
Fst. Stage F-Stat & 1859.1 & 1859.1 & 1859.1 & 1849.7 & 1859.1 \\
Obs. & 68842 & 68842 & 68842 & 67192 & 68842 \\
\hline
\end{tabular}

B. Using Weighted Average of Present Discounted Values of Obligations

$\begin{array}{lccccc}\begin{array}{l}\text { Weighted average } \\ \text { of PDVs of obligations }\end{array} & \begin{array}{c}0.676^{* * *} \\ {[0.0509]}\end{array} & \begin{array}{c}-0.00730^{* * *} \\ {[0.00268]}\end{array} & 0.00900^{* * *} & 0.00776^{* * *} & 0.00278^{* * *} \\ & & & & & \\ & & 0.00152] & 0.00133] & 0.000730] \\ \text { Mean, dept. var. } & 9.263 & 0.278 & 0.186 & 0.185 & 0.0418 \\ \text { Fst. Stage Coef. } & 0.655 & 0.655 & 0.655 & 0.656 & 0.655 \\ \text { Fst. Stage F-Stat } & 1213.6 & 1213.6 & 1213.6 & 1207.0 & 1213.6 \\ \text { Obs. } & 70468 & 70468 & 70468 & 68772 & 70468\end{array}$

C. Using Fathers' Predetermined Characteristics to Predict Future Obligations

$\begin{array}{lccccc}\text { Average child } & 0.534^{* * *} & -0.00329^{*} & 0.00534^{* * *} & 0.00295^{* * *} & 0.00426^{* * *} \\ \text { support obligation } & {[0.0383]} & {[0.00181]} & {[0.00124]} & {[0.00109]} & {[0.000559]} \\ & & & & & \\ \text { Mean, dept. var. } & 9.263 & 0.278 & 0.186 & 0.185 & 0.0418 \\ \text { Fst. Stage Coef. } & 0.674 & 0.674 & 0.674 & 0.677 & 0.674 \\ \text { Fst. Stage F-Stat } & 2396.2 & 2396.2 & 2396.2 & 2390.5 & 2396.2 \\ \text { Obs. } & 70468 & 70468 & 70468 & 68772 & 70468\end{array}$

D. Controlling for the Father's Post-Separation Income

$\begin{array}{lccccc}\text { Average child } & 0.500^{* * *} & -0.00602^{* * *} & 0.00685^{* * *} & 0.00621^{* * *} & 0.00286^{* * *} \\ \text { support obligation } & {[0.0381]} & {[0.00210]} & {[0.00118]} & {[0.00104]} & {[0.000550]} \\ & & & & & 0.185 \\ \text { Mean, dept. var. } & 9.263 & 0.278 & 0.186 & 0.813 & 0.812 \\ \text { Fst. Stage Coef. } & 0.812 & 0.812 & 0.812 & 0.813 \\ \text { Fst. Stage F-Stat } & 2431.3 & 2431.3 & 2431.3 & 2424.8 & 2431.3 \\ \text { Obs. } & 70468 & 70468 & 70468 & 68772 & 70468\end{array}$

Notes: "F." refers to fathers' outcomes, while "M." refers to mothers' outcomes. Each coefficient in each panel is from a separate regression. In Panel A, results are from specifications where average predicted obligations (which are used to instrument for actual average obligations) are calculated based on the father's income measured in the year before separation. In Panel B, results are from specifications where the key explanatory variable is a weighted average of the net present discounted values (NPVs) of obligations in each year post-separation, assuming a 3 percent real discount rate. We use the predicted weighted average (with obligations set according to the father's separation year income and number of children) to instrument for the actual weighted average. In Panel C, results are from specifications where the average predicted obligation is calculated using the father's predicted income in years post-separation. Specifically, we first regress the father's income in each year postseparation on a set of pre-determined characteristics observed in the separation year:the father's separation year income, the father's age and age squared, dummies for the father's education (less than high school, high school, vocational/short-term higher ed, college/university, and missing), and an indicator for the father being from Western Europe. We then use the father's predicted income in each year post-separation to calculate his average predicted obligation, which we then use to instrument for his actual average obligation. In Panel D, results are fromp ppecifications that control for the father's income in each year post-separation. All income variables are in year 2000 real units of 1,000 DKK. See notes under Appendix Table A3 and Table 3 for more information on the sample, specifications, and controls. Standard errors robust to heteroskedasticity.

Significance levels: $* \mathrm{p}<0.1 * * \mathrm{p}<0.05 * * * \mathrm{p}<0.01$ 


\section{B A Theoretical Model}

In Section 3, we described some mechanisms by which fathers' child support obligations may impact parental behavior. Here, we formalize these channels using a model. Our framework draws on several existing models of interaction between divorced and unmarried parents (e.g., Weiss and Willis, 1985; Del Boca and Flinn, 1995; Willis, 1999; Flinn, 2000; Del Boca and Ribero, 2003; Roff and Lugo-Gil, 2012).

Consider a set of separated parents with one child between them, where mothers are denoted by subscript $m$ and fathers are denoted by subscript $f$. Each parent obtains utility from child quality, $Q$, their own private adult consumption, $C$, and their leisure time, $L .{ }^{43}$ Utility from child quality is comprised of two components: $Q^{0}$ (current child quality) and $Q^{1}$ (child quality from a possible subsequent child born within a new union). For simplicity, we do not explicitly model future children born outside marriage/cohabitation; however, we discuss how incorporating this decision into the model would affect the main conclusions below. For each parent $i \in\{m, f\}$, denote the number of subsequent children by $n_{i}$, where $n_{i}$ can take on integer values $\{0,1,2, \ldots\}$.

Additionally, assume that child quality is a function of two types of investments: financial, $F$, and time, $K$. Denote the financial and time investments in the current child by $F^{0}$ and $K^{0}$, respectively. For mothers' subsequent children, financial and time investments are $F_{m}^{1}$ and $K_{m}^{1}$, respectively; for fathers' subsequent children, financial and time investments are $F_{f}^{1}$ and $K_{f}^{1}$, respectively. We do not make any assumptions about whether the financial and time investments are substitutes or complements in the child quality function; although we discuss the implications of such assumptions further below.

In terms of time allocation, each parent must divide his/her time between work in the labor market (denoted by $H$ ), time investments into children, and leisure. Each parent $i \in\{m, f\}$ earns wage $w_{i}$ in the labor market, and total time available is denoted by $T$.

We assume that the separated parents do not bargain cooperatively and instead face a static Stackelberg game. ${ }^{44}$ In this setting, the non-custodial father can make two types of transfers to the custodial mother: a financial transfer, $s$, and a time transfer, $t$. The custodial mother chooses how to allocate these transfers. Intuitively, we can think of the time transfer as the amount of extra time freed up for the mother as a result of the father offering to spend time with the child. ${ }^{45}$

\footnotetext{
${ }^{43}$ Note that our framework differs from the model in Neal (2004), which assumes that "absent fathers do not enjoy any consumption gains from having children". We instead follow Willis (1999) and Flinn (2000) (among many others) by assuming that non-custodial fathers in fact obtain utility from child quality. This assumption is arguably more realistic in our setting, where an estimated 20 percent of Danish children with divorced or separated parents have fathers who share in their physical custody (Bjarnason and Arnarsson, 2011), and another 45 percent have non-custodial fathers who visit with them at least every other weekend (Kampmann and Nielsen, 2004).

${ }^{44}$ The non-cooperation assumption is common in the literature on non-intact families (e.g., Weiss and Willis, 1985; Del Boca and Flinn, 1995; Willis, 1999; Roff and Lugo-Gil, 2012). In an important contribution, Flinn (2000) instead develops a model where separated parents can choose between cooperative and non-cooperative equilibria, and where institutions (e.g., judges determining child support or custody settlements) are modeled as coordination devices. Such a model is useful for generating predictions about the impacts of changes to institutional enforcement capabilities. For example, a key result of the model is that when institutions can perfectly enforce compliance with child support obligations, the custodial parent loses the incentive to engage in cooperative behavior; for a large set of parental preferences, perfect child support enforcement can thus lead to lower child investments relative to imperfect enforcement. In our case, the empirical analysis uses variation in child support obligation amounts, rather than in the degree of institutional enforcement (in fact, enforcement does not change throughout our sample time frame). As such, we do not take this approach, and instead assume perfect complicance with child support obligations (see below).

${ }^{45}$ This set-up implicitly assumes that maternal and paternal time investments are perfect substitutes. Instead, it may be that mothers view paternal time investments as less productive than their own. Such an assumption can be modeled by multiplying $t$ by some parameter $0<\rho<1$ in the mother's maximization problem below. Alternatively, mothers may place greater weight on paternal time investments if they think it is important for children to spend time with a male role model. This assumption
} 
For subsequent children, we assume that the parents expect to bargain cooperatively with new partners. Each parent $i$ expects to be responsible for fraction $\lambda_{i}^{F}$ of the total financial investment and fraction $\lambda_{i}^{K}$ of the total time investment per subsequent child born.

More concretely, $\forall i \in\{m, f\}$ parental utility is represented by the following function:

$$
U\left(Q^{0}, Q_{i}^{1}, n_{i}, C_{i}, L_{i}\right)=\beta_{i} U_{c}\left(Q^{0}\left(F^{0}, K^{0}\right), n_{i} * Q^{1}\left(F_{i}^{1}, K_{i}^{1}\right)\right)+\left(1-\beta_{i}\right) U_{a}\left(C_{i}, L_{i}\right)
$$

where $U_{c}(\cdot)$ represents utility from children, $U_{a}(\cdot)$ represents utility from adult activities, and $\beta_{i}, 0<\beta_{i}<1$, represents the weight each parent places on his/her preferences toward children relative to other adult consumption goods. ${ }^{46}$

The mother chooses the optimal current and subsequent child investments, the number of subsequent children she will have, and her own adult consumption and leisure, conditional on the father's transfers, $s$ and $t: 47$

$$
\begin{gathered}
\max _{F^{0}, K^{0}, n_{m}, F_{m}^{1}, K_{m}^{1}, C_{m}, L_{m}} \beta_{m} U_{c}\left(Q^{0}\left(F^{0}, K^{0}\right), n_{m} * Q^{1}\left(F_{m}^{1}, K_{m}^{1}\right)\right)+\left(1-\beta_{m}\right) U_{a}\left(C_{m}, L_{m}\right) \\
\text { s.t. } \quad F^{0}+n_{m} \lambda_{m}^{F} F_{m}^{1}+C_{m}=w_{m}\left(T-L_{m}-K^{0}+t-n_{m} \lambda_{m}^{K} K_{m}^{1}\right)+s
\end{gathered}
$$

The father then maximizes his indirect utility function, taking into account the maternal optimal response functions for current child investments, $F^{0}(s, t)^{*}$ and $K^{0}(s, t)^{*}$. He chooses his optimal financial and time transfers for the current child, the number of subsequent children he will have, his investments into subsequent children, his private adult consumption, and his time spent in leisure. Additionally, we assume that for the current child, the father is subject to a child support mandate, $R$, which depends on his earned income, his number of children, and his time transfer, and is defined further below. The father thus solves the following problem:

$$
\begin{gathered}
\max _{s, t, n_{f}, L_{f}, F_{f}^{1}, K_{f}^{1}}\left\{\beta_{f} U_{c}\left(Q^{0}\left(F^{0}(s, t)^{*}, K^{0}(s, t)^{*}\right), n_{f} * Q^{1}\left(F_{f}^{1}, K_{f}^{1}\right)\right)\right. \\
\left.+\left(1-\beta_{f}\right) U_{a}\left(w_{f}\left(T-L_{f}-t-n_{f} \lambda_{f}^{K} K_{f}^{1}\right)-s-n_{f} \lambda_{f}^{F} F_{f}^{1}, \quad L_{f}\right)\right\} \quad \text { s.t. } \quad s \geq R\left(w_{f} H_{f}, n_{f}, t\right)
\end{gathered}
$$

The child support obligation for the current child, $R\left(w_{f} H_{f}, n_{f}, t\right)$, is set according to a formula that depends on the father's earned income, $w_{f} H_{f}$, his total number of biological children $\left(n_{f}+1\right)$, and his time transfer, $t$, in a way similar to the actual Danish child support guidelines that we study. In particular,

can be modeled by multiplying $t$ by some parameter $\rho>1$ in the mother's maximization problem. The main conclusions of the model remain qualitatively similar.

${ }^{46}$ While we do not make any assumptions about a particular functional form of the utility function in this discussion, we note that the utility function in this framework must allow for corner solutions as $n_{i}$ is allowed to be set to zero. More formally, it must be that $\lim _{x \rightarrow 0} U^{\prime}(x) \neq \infty$.

${ }^{47}$ Prices of consumption goods are normalized to 1 for simplicity. 


$$
R\left(w_{f} H_{f}, n_{f}, t\right)=\left\{\begin{array}{lll}
\xi & \text { if } w_{f} H_{f} \leq \bar{Y}_{n_{f}} \text { and } t \leq \bar{t} \\
\xi+\tau & \text { if } w_{f} H_{f}>\bar{Y}_{n_{f}} \text { and } t \leq \bar{t} \\
0 & \text { if } t>\bar{t}
\end{array}\right.
$$

for some $\xi>0, \tau>0$, and $\bar{t}>0$. Additionally, $\bar{Y}_{n_{f}}>0$ and is strictly increasing in $n_{f}$. In other words, the guidelines are set such that fathers must pay a base amount, $\xi$, and fathers with incomes above some threshold, $\bar{Y}_{n_{f}}$, face an additional obligation of $\tau$. The location of $\bar{Y}_{n_{f}}$ is increasing with the father's subsequent number of children, $n_{f}$. The child support constraint is removed once fathers make high enough time transfers, $t$. For example, in our context, fathers who share equally in physical custody of their children do not need to pay child support.

Denote the father's optimal financial transfer by:

$$
s^{*}=\max \left(s^{u n c}, R(\cdot)\right)
$$

where $s^{u n c}$ is the (unconstrained) solution to the father's optimization problem if the child support mandate constraint is not binding. ${ }^{48}$

\section{B.1 Possible Effects on Parental Behaviors}

Consider two child support obligation schemes: $R_{1}\left(w_{f} H_{f}, n_{f}, t\right)$ and $R_{2}\left(w_{f} H_{f}, n_{f}, t\right)$, with $\xi_{2}>\xi_{1}$ and $\tau_{2}>\tau_{1}$. What happens to parental behaviors when we increase the child support obligation from $R_{1}$ to $R_{2}$ ? Our model highlights the theoretical ambiguity of this question with regard to the following parental behaviors:

Fathers' Financial Transfers Consider three possible cases that depend on what fathers' financial transfers would have been in the absence of government intervention:

First, if $s^{u n c} \geq R_{2}$, the father optimally transfers as much or more than what is mandated under the higher obligation, $R_{2}$. This father will not alter $s^{*}$ in response to a switch from the lower to the higher obligation.

Second, if $R_{1}<s^{u n c}<R_{2}$, then the father would optimally pay more than the lower obligation, $R_{1}$, but less than the higher obligation, $R_{2}$. When faced with a change from $R_{1}$ to $R_{2}$, it may be optimal for the father to increase $s^{*}$ from $s^{u n c}$ to $R_{2}$. The magnitude of this increase is strictly less than the difference between the two schemes, $R_{2}-R_{1}$. However, as discussed further below, some fathers may also respond by having more children or lowering their labor supply so to reduce their $R_{2}$ obligations from $\xi_{2}+\tau_{2}$ to $\xi_{2}$. If $\xi_{2}<s^{u n c}<\xi_{2}+\tau_{2}$, then there may be a decrease in $s^{*}$ from $s^{u n c}$ to $\xi_{2}$.

\footnotetext{
${ }^{48}$ As noted, we assume perfect compliance with child support mandates and do not model the compliance decision. This decision is modeled explicitly through an incorporation of a cost associated with non-compliance in Del Boca and Flinn (1995) and Flinn (2000). Modeling the compliance decision is important in a setting where the degree of institutional enforcement changes and child support obligations are set endogenously (e.g., by judges). In our case, enforcement is stable over the analysis time frame, and we argue that our variation in child support obligations is policy-driven and exogenous.
} 
Third, if $s^{u n c} \leq R_{1}$, then the father would optimally pay less than the lower obligation. There are two possibilites for these fathers as well. Some fathers may increase $s^{*}$ exactly from $R_{1}$ to $R_{2}$ (either from $\xi_{1}$ to $\xi_{2}$ or from $\xi_{1}+\tau_{1}$ to $\xi_{2}+\tau_{2}$ ). However, as before, if some fathers respond by having more children or lowering their labor supply, $s^{*}$ may instead change from $\xi_{1}+\tau_{1}$ to $\xi_{2}$, which may reflect either an increase or a decrease in optimal payments, depending on whether $\xi_{2}$ is smaller or larger than $\xi_{1}+\tau_{1}$.

Thus, while increases in child support obligations are predicted to increase some fathers' financial transfers to their children, this relationship is complicated by other paternal behaviors, and may not be one-for-one on average. Some fathers may just substitute for non-mandated transfers that they would have made in the absence of government intervention. Additionally, fertility and labor supply responses may even lead to a perverse relationship between child support mandates and actual payments.

Fathers' Time Investments There are two opposing forces on fathers' time investments. On the one hand, since fathers who make high enough time transfers do not face the child support mandate, a higher obligation may lead to an increase in $t^{*}$ as the father can forego a larger financial cost by being above $\bar{t}$. Additionally, if the higher obligation increases the father's financial transfer, then paternal time transfers may also increase if financial and time investments are complements in the child quality function.

On the other hand, a higher obligation increases the maternal incentive to actually receive the higher mandated financial transfer by ensuring (via her optimal response functions) that the father's time transfer does not exceed $\bar{t}$. In our setting, when the father is faced with the higher obligation, the mother has a greater incentive to make sure that the father does not share in physical custody. ${ }^{49}$ Moreover, as above, the impacts on time transfers also depend on the child quality function, and there may be additional downward pressure on paternal optimal time transfers, if financial and time investments are substitutes.

Both Parents' New Family Formation Fathers face complex fertility incentives. First, for fathers with incomes below the threshold, $\bar{Y}_{n_{f}}$, a higher obligation represents a negative income effect, which may decrease subsequent fertility. However, since the income threshold is increasing in the number of subsequent children, and since the father is only mandated to make financial transfers to his one existing non-custodial child, some (higher-income) fathers have an incentive to have more children so to reduce their child support obligation from $\xi+\tau$ to $\xi$. Additionally, for fathers at all income levels, higher obligations may lead to less time spent with existing children, $t^{*}$, freeing up time available to invest in future children.

For mothers, consider the case where higher obligations increase fathers' financial transfers. For them, higher obligations constitute larger positive income effects, resulting in greater investments in current children as well as greater demand for subsequent children. Mothers also face an opposite incentive to lower subsequent fertility because their time available to invest in subsequent children may be lower as a result of a reduction in the paternal time transfer.

Moreover, although we do not model this explicitly, there are different incentives for mothers' and fathers' subsequent fertility outside marriage and cohabitation. In particular, although a father may lower his per-child obligation by having more children out-of-wedlock/cohabitation (since the income threshold is increasing in his total number of children), fertility within unions is relatively less costly as he is only subject to child support mandate for his out-of-union children. By contrast, a mother may have larger incentives

\footnotetext{
${ }^{49}$ In practice, parents can either agree on a custody arrangement or go to the court if they are unable to reach an agreement. Hence, if the mother refuses to share physical custody, the father can in principle take the issue to court. However, prior to a reform in October 2007, which made joint legal custody the default determination (and hence made joint physical custody more likely as well), courts were likely to rule in favor of maternal sole custody. Thus, it is reasonable to assume that, during our sample time frame of 1999-2008, mothers had substantial influence over the custody decision.
} 
for childbearing outside unions because the receipt of a higher payment for her existing child may increase her expectation of child support transfers associated with subsequent offspring from new partners. ${ }^{50}$

Both Parents' Labor Market Behavior Fathers face opposing labor supply incentives. For a father with earnings below the threshold, $\bar{Y}_{n_{f}}$, the child support obligation is a flat negative income shock in the amount of $\xi$. This shock is predicted to reduce demand for leisure and increase labor supply. In contrast, a father with an income above the threshold faces a type of tax on earnings. This higher-income father has an incentive to lower his labor supply in order to reduce his income and avoid paying the additional $\tau$ amount.

For a mother, again consider the case where a higher obligation increases the father's financial transfer. The child support obligation is then a positive income shock that is not dependent on her own earned income. As such, we may expect an increase in maternal demand for leisure and therefore a reduction in her labor supply. Additionally, maternal labor supply may also be affected by possible changes to her time available to work due to impacts on the father's time transfer.

\section{Evidence on Physical Custody Arrangements, In-Kind Transfers, and Child Support Payments from Survey Data}

In Section 4, we argue that an important factor driving the zero payments we observe in our data is joint physical custody arrangements. Unfortunately, the administrative data we use contain an imperfect measure of physical custody based on whether the child is registered at the same address as the parent. As children can only have one address in our data (irrespective of their custody arrangement), we underestimate joint physical custody arrangements by looking at children who are registered at the same address as their fathers.

To further examine the relationship between physical custody arrangements and child support payments, we link our administrative data to survey data from Denmark. As sample sizes for children living in nonintact families in available surveys are small, we pool data from two sources: first, the 2007 wave of the Danish Longitudinal Survey of Children (DALSC), and second, the 2009 wave of the Children and Youth in Denmark (CYD) survey. ${ }^{51}$ The DALSC is a panel study of all children born in Denmark in one week of October 1995. The CYD is a survey conducted among random samples of seven cohorts aged 3-19 in 2009 and 2013. Both panel studies examine a broad set of topics related to children's living conditions, including custody arrangements.

We link the survey information to the administrative data on child support payments. Similar to our sample construction described in Section 4, we keep children whose fathers are in the administrative data in all years after 1995 (the initiation year of the DALSC). We match 5,738 DALSC and 5,988 CYU children to the administrative data (99/95\% of the children with completed survey questionnaires). In 2007, the DALSC children were 12 years old and thus we have a relatively large share of children who have experienced a parental separation: After conditioning on the fathers being in the data for all years after 1995 and experiencing a separation at any time during the period, we end up with 2,024 separated fathers with (singleton) children. For the CYD data, we end up with 1,428 fathers.

As we use parental reports on physical custody arrangements (the vast majority of questionnaires were completed by mothers), we further condition on the parents having answered questions on the custody

\footnotetext{
${ }^{50}$ Note that all of these fertility responses for fathers and mothers are relevant insofar as we hold the fertility responses of the other parents constant. As these parents are all arguably in the same matching market post-separation, the net effects on overall parental fertility rates also depend on the numbers of men and women and their relative bargaining powers.

${ }^{51}$ For details on the DALSC and CYU please see http://www.sfi.dk/about_the_research-11402.aspx and http://www.sfi.dk/children_and_young_people_in_denmark-7395.aspx.
} 
arrangements (i.e., separated before the surveys in 2007/2009). Finally, we only look at one- and twochildren families with fathers in the relevant income range (around the guideline thresholds), as in the main analysis. Our final survey sample consists of parents of 819 DALSC and 702 CYD children for a total sample size of 1,521 .

Appendix Table C1 divides this sample of children into three groups: Column 1 reports summary statistics for the full survey sample of children with separated parents. Columns 2 and 3 show summary statistics for the two sub-groups: children with sole-mother and children with either joint or sole-father physical custody arrangements as reported in the respective survey years (2007 for DALSC and 2009 for CYD). Joint physical custody is defined as the child spending approximately half of the time with each parent (in the survey year). Given that we only have 43 fathers with sole physical custody in our data, and as paternal child support obligations do not apply to both joint and sole physical custody fathers, we pool the two groups.

In the top panel, we report means and standard deviations of some of the child support variables from the administrative data. While our main analysis focuses on fathers' child support obligations and payments, we also describe maternal child support payments here as they are especially relevant for the joint and sole-father physical custody arrangements.

We find that fathers who share in the physical custody in the survey year (and especially if they have sole custody) pay less child support over the separation time relative to fathers who do not. The percentage of fathers with zero payments is higher among fathers who have sole or joint physical custody in the survey year: 46 percent of sole- or joint-custody fathers make zero payments in that year (relative to 34 percent of fathers whose children live in sole-mother custody arrangements). These figures illustrate that a large share of the zeros we observe in our administrative data is likely driven by fathers who share in physical custody of their children.

Additionally, while the 22 percent of fathers with joint or sole physical custody in the survey year pay less than their non-custody counterparts, the survey data also show that mothers pay more in these cases: Mothers of children in sole-father or joint physical custody arrangements pay more than four times as much as sole-custody mothers, and are less likely to ever have zero payments after separation. However, the relatively low level of average post-separation mother payments reflects that mothers are most likely to have physical custody of their children in some (if not all) of the pre-survey separation years.

The last row in the top panel shows that our measure of father-child co-residence - an indicator for the father having the same address as the child in any year post-separation - is reasonable (although imperfect). Fathers who have joint or sole physical custody are more likely to be registered at the same address as their child relative to fathers of children in sole-mother custody arrangements.

Finally, the lower panels of the table focus on variables only available in two waves of the DALSC. First, we look at the same sample of children in the 2007 DALSC and their parents' reports from any of the survey years $(1996,1999,2003,2007,2011)$. These data show that joint physical custody arrangements are relatively fluid over separation time: among parents who have a sole-mother arrangement in 2007, 13 percent have joint custody in any of the survey years. Overall, 33 percent of parents have a joint custody arrangement in at least one of the survey years.

Second, we use the 1999 DALSC wave to look at the prevalence of gifts and other in-kind transfers between separated parents. ${ }^{52}$ We find that in-kind transfers are relatively uncommon: 19 percent of fathers have bought winter clothing for their children and only around four percent of fathers contributed to the costs of child care.

In sum, using the available survey data (linked to our administrative data), we find that joint (and

\footnotetext{
${ }^{52}$ Unfortunately, we only have survey information on this topic in the 1999 wave of the survey. In this year, the DALSC children are three years old and thus we have even fewer children in families which have separated.
} 
sole-father) physical custody arrangements (which we underestimate when using only administrative data on addresses) coincide with lower average father child support payments, higher prevalence of zero payments by fathers, and higher average mother payments. Moreover, as around 33 percent of parents have a joint physical custody arrangement at some point post-separation, and as parents sharing physical custody do not face child support mandates, we conclude that a large percentage of the observed zero-payments in our main analysis data set is attributable to the prevalence of these arrangements. Finally, in-kind transfers between parents (that are not included in the mandated or voluntary child support payments that we observe) appear to be relatively uncommon in the Danish setting. 
Table C1: Physical Custody Arrangements and Child Support Payments: Evidence from Administrative Data Linked to Survey Data from DALSC (1999, 2007) and CYD (2009)

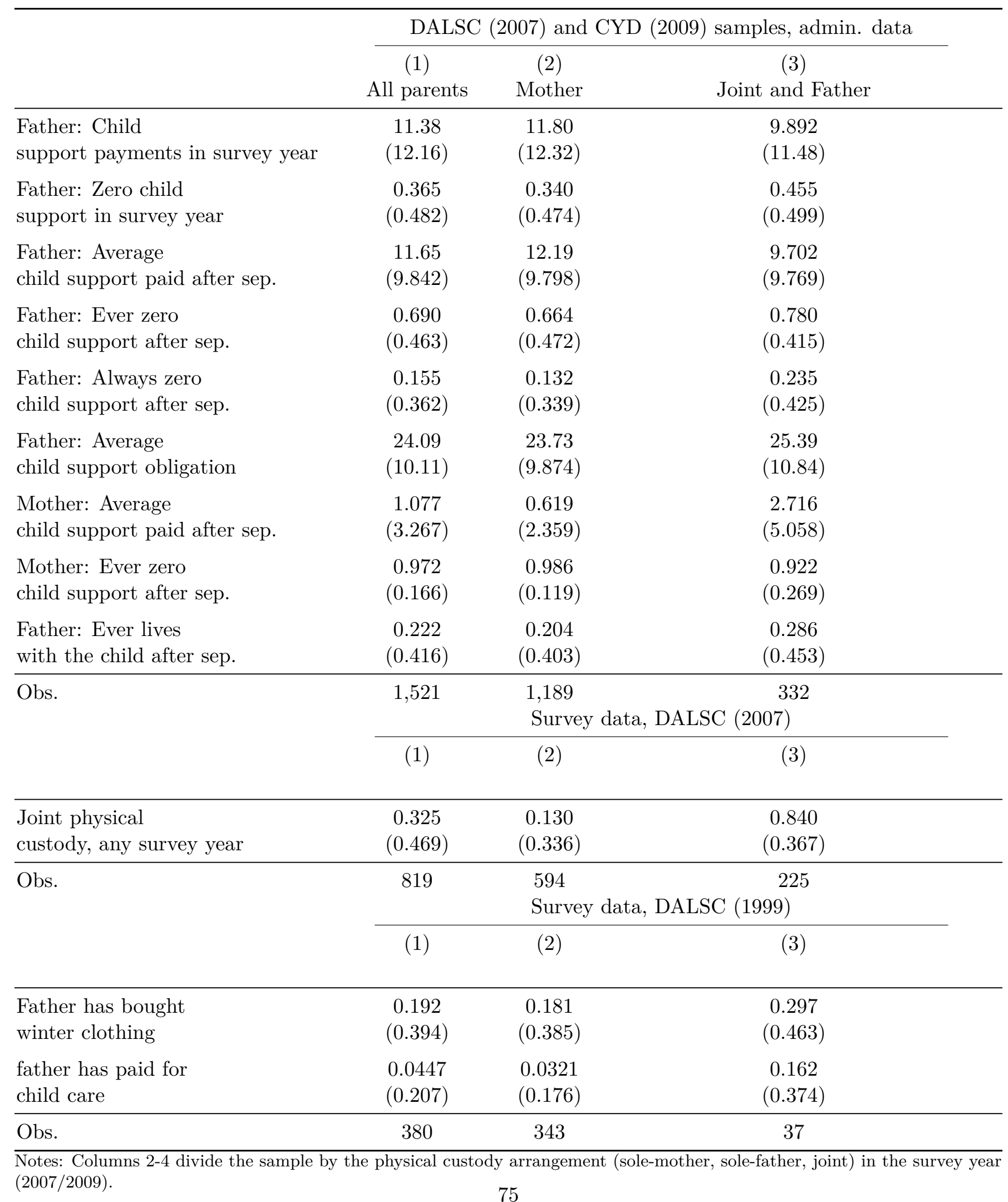

